\title{
Leren in de eerste lijn : afscheid van prof. dr. H.F.J.M. Crebolder
}

Citation for published version (APA):

Knottnerus, J. A. (2002). Leren in de eerste lijn : afscheid van prof. dr. H.F.J.M. Crebolder.

Capaciteitsgroep Huisartsgeneeskunde. https://doi.org/10.26481/spe.20020607ak

Document status and date:

Published: 07/06/2002

DOI:

10.26481/spe.20020607ak

Document Version:

Publisher's PDF, also known as Version of record

\section{Please check the document version of this publication:}

- A submitted manuscript is the version of the article upon submission and before peer-review. There can be important differences between the submitted version and the official published version of record.

People interested in the research are advised to contact the author for the final version of the publication, or visit the DOI to the publisher's website.

- The final author version and the galley proof are versions of the publication after peer review.

- The final published version features the final layout of the paper including the volume, issue and page numbers.

Link to publication

\footnotetext{
General rights rights.

- You may freely distribute the URL identifying the publication in the public portal. please follow below link for the End User Agreement:

www.umlib.nl/taverne-license

Take down policy

If you believe that this document breaches copyright please contact us at:

repository@maastrichtuniversity.nl

providing details and we will investigate your claim.
}

Copyright and moral rights for the publications made accessible in the public portal are retained by the authors and/or other copyright owners and it is a condition of accessing publications that users recognise and abide by the legal requirements associated with these

- Users may download and print one copy of any publication from the public portal for the purpose of private study or research.

- You may not further distribute the material or use it for any profit-making activity or commercial gain

If the publication is distributed under the terms of Article $25 \mathrm{fa}$ of the Dutch Copyright Act, indicated by the "Taverne" license above, 


\section{Leren in de eerstelijn}

7 juni 2002

ISBN:

Redactie:

$$
\text { 90-74474-07-1 }
$$

J. A. Knottnerus, J. M.H. op 't Root, I. Siegelaer Capaciteitsgroep Huisartsgeneeskunde Universiteit Maastricht Postbus 616,6200 MD Maastricht

Omslag:

Druk:

Oplage: MTB Grafisch bedrijf MTB Grafisch bedrijf 1000 



\section{Inhoud}

Voorwoord

Over gezinsrelaties en genetische epidemiologie Frank Buntinx

Mensen met mogelijkheden

Bert Schadé

De patiënt, zijn gedaanten, en de vraag André Knottnerus

Tussen gezondheidscentrum en geacademiseerde huisartspraktijk

Chris van Weel

Make my day

Hans Fiolet

Het Gezondheidscentrum Withuis, werkplaats voor nieuwe ontwikkelingen

Tonnie van Kessel, namens het Withuis

Huisarts Harry Crebolder: een persoonlijkheid Tonnie van Kessel

Afscheid van Harry

Annie Hendriks

Een professor neemt afscheid, en neemt de huisarts met zich mee Jan van Rooij

Help, de huisdokter verzuipt!

Jos van Engelshoven 
Prof. dr. H.F.J.M. Crebolder: Acht jaar lid van het STOOM-bestuur

Joop van Londen

Transmurale zorg: van DCM naar BZe VII,

azM 1979-2002

Peter Pop

Harry en HAG: Paradigma in persoon

George Beusmans en Job Metsemakers

Harry Crebolder en het azM

Jan Carpay en Lou Brans Brabant

Transmurale zorg: levenslang samenwerken

Betty Meyboom-de Jong

Harry Crebolder, pleitbezorger van de generalistische geneeskunde

Fred Sturmans en Jos Schols

Een bevlogen dokter

Cor Spreeuwenberg

"Old soldiers never die, some of them will

not even fade away"

Geertian Wesseling

Stageoverstijgend klinisch onderwijs; integratie tussen lijnen en disciplines

Gerard Essed

Voor een paar dollars meer

Harry Hillen 
Harry

Gauke Kootstra

De verantwoordelijkheid voor de eigen professie:

de inbreng van de opleiders in de huisartsopleiding Jan van Ree

Harry Crebolder en de Experimentele Kaderopleiding Huisartsen Jan van Es

Kaderopleiding Huisartsgeneeskunde Maarten Klomp en Ted van Essen

De kwaliteitskant van Harry

Richard Grol

Multidisciplinair onderzoek in de huisartsgeneeskunde; een contradictio in terminis?

onno van Schayck

Harry als promotor

Paul Stalenhoef

Harry Crebolder

Patrick Smeets.

Op geleide van Harry op zoek naar de horizon van de huisarts, de huisartsgeneeskunde en hemzelf Frans van der Horst

Over leiderschap gesproken

Jos op "t Root

Harry Crebolder, een man met vele gezichten!

René Kocken 
Beheer: van punaise tot pre-advies Ellen Breevoort

Een goede toekomst ligt in een rijk verleden Yvonne van Leeuwen

'Goeie moed Harry, ut kump good' ine Siegelaer 


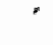


(1) 
Aan de fraale en veelzeggende titels van de inaugurele rede en de afscheidsrede van Harry F.J.M. Crebolder, respectievelijk 'Te leer in de eerste lijn' (1987) en vijftien jaar later 'Geleerd in de eerstelijn' (2002) is nauwelijks iets toe te voegen. Maar 'Leren in de eerste lijn' past zeker in dit rijtje en, als Harry nog een keer een rede had kunnen houden, zou hij daarvoor misschien wel hebben gekozen. Leren, actief en passief, en in wederkerigheid, is immers het proces dat allen in de zorg en de academia samenbindt.

De patiënt kan in de loop der jaren veel van zijn arts leren. Maar niet minder steekt de arts op van zijn patiënten, of het nu gaat om de hoogtepunten dan wel de dieptepunten in het persoonlijke en beroepsbestaan. Deze creatieve interactie is des te sterker in de huisartsgeneeskunde, waarbinnen patiënt en huisarts vaak vele jaren met elkaar optrekken, in voor-en tegenspoed.

De student en de huisarts-in-opleiding doen niet alleen veel kennis, vaardigheden en inzichten op, maar zij geven ook veel terug aan hun (hoog)leraren en opleiders. Zij staan immers bij uitstek fris en kritisch tegenover het vak en de stof, en dat is een onmisbare motor van verbetering en vooruitgang.

Promovendi hebben veel aan een deskundige en gedreven promotor, maar zorgen er tegelijk voor dat een té gedreven promotor mild corrigerende feedback krijgt. Tegelijkertijd zijn juist zij, dichtbij als zij zijn bij de top van hun eigen kunnen en het kunnen van de wetenschap, bij uitstek de brengers van vernieuwing. De taak van de promotor is dan ook niet het altijd beter te weten dan de promovendus, maar er toe uit te dagen onvermoede inzichten te ontvouwen.

Wederzijds leren hoort er ook te zijn bij artsen en andere hulpverleners onderling, binnen en tussen de eerste en de tweede lijn. Alleen dan kunnen zij buiten het eigen blikveld reiken, en dat is voorwaarde voor bundeling van expertise en voortgaande innovatie van zorg.

Harry Crebolder heeft het grote belang van het leren in al deze betekenissen als geen ander gezien en voorzien, vanaf de eerste dag van zijn lange loopbaan. Het leren in de stijl van Crebolder is een garantie voor nimmer aflatende ontwikkeling. Dat komt ook tot 
uiting in de titel van zijn afscheidssymposium: 'De toekomst van de huisartsgeneeskunde: continuiteit en vernieuwing'. Continuiteit van zorg, zo kenmerkend voor de huisartsgeneeskunde, kenmerkt ook de wijze waarop Harry steeds met zijn opdracht en 'zijn mensen' is omgegaan. In de manier waarop hij zelf onvermoeibaar vernieuwend is bezig geweest, was hij een motiverend voorbeeld. In het vak en in de mensen die het uiteindelijk moeten doen, heeft hij daarmee een stevige basis gelegd voor de toekomst.

Deze bundel met inhoudelijke en persoonlijke bijdragen is geïspireerd door het leren van en met Harry. Wij hebben een aantal personen, allen goede bekenden van Harry, uitgenodigd gevraagd om in hun bijdrage uit te gaan van een inhoudelijk thema. Daarbij zou mooi zijn dat te koppelen aan situaties die hebben gespeeld of nog spelen in de tijd dat Harry huisarts en hoogleraar was, en een passend persoonlijk tintje was welkom. Het thema kon dus gaan over iets dat vroeger belangrijk was, dat nu actueel is of waarvan de auteur zou verwachten dat het in de toekomst een rol zou spelen. We hebben getracht daarbij enige ordening aan te brengen. Het eerst aan bod komen de bijdragen die betrekking hebben op de erstelijnsgezondheidszorg. Transmurale zorg krijgt daarna de aandacht. Dan volgen onderwijs en onderzoek en tenslotte bijdragen die meer betrekking hebben op de capaciteitsgroep

Huisartsgeneeskundle. Een strakke ordening is het niet, maar we wilden $u$ toch graag enig richtingsgevoel bijbrengen. Wat ons behalve de rijke inhoud van de bijdragen verraste was de prettige stuurloosheid die de diverse auteurs, overwegend academici, hebben getoond bij het interpreteren van de opdracht. Als onze studenten zo met de opdrachten voor werkstukken zouden omgaan!? Maar de vrije, creatieve interpretatie van de opdracht zoals die blijkt uit de bijdragen, past goed bij Harry die, behalve hoog en leraar, ook altijd ontdekker is van onvermoede doch betere richtingen.

\section{7 juni 2002}

André Knottnerus

Jas op 't Root 


\section{O ver gezinsrelaties en genetische epidemiologie}

Frank Buntinx.

Tot ongeveer een decennium geleden was gezinsgeneeskunde een belangrijk onderwerp van studie in de huisartsgeneeskunde $(1,2)$. In ons taalgebied bleek dit onder meer uit het werk van de ondertussen overleden hoogleraar Frans Huygen en van de Vlaams-Nederlandse Werkgroep Gezinsgeneeskunde. Harry was éen van de leden van die werkgroep. Ik denk trouwens dat ik hem daar voor het eerst ontmoet heb. Ik zie hem alleszins nog steeds gezwind de vergaderzaal binnenkomen met de schoudertas waarmee ik hem sindsdien nog zo dikwijls gezien heb. Internationaal genoot het Amerikaans tijdschrift Family Systems Medicine toen veel aanzien. In dezelfde periode dat de Vlaams-Nederlandse werkgroep ter ziele ging, werd het ook internationaal stil rond gezinsgeneeskunde. De aandacht verschoof naar een meer biologisch-technische benadering van ziekte en gezondheid. Het gezin werd nog wel in onderzoek betrokken waar het ging om de consequenties van aandoeningen, maar daar bleef het meestall ook bij (3).

Eén van de onderzoekers die ook in die stille periode gezinsgeneeskundig actief gebleven is, is Harry Crebolder. In 1986 was hij de eerste auteur van een artikel in Huisarts en Wetenschap over de begeleiding van diabetespatiënten met daarin een heel onderdeel over de effecten van gezinsrelaties op de compliance (4). De reflex om dit in de anallyse mee te betrekken was toen, en overigens ook vandaag nog, zeker niet vanzelfsprekend. In 1992 ging hij, samen met Frans van der Horst, Job Metsemakers en Gregor Franssen, nog een stap verder met een studie op basis van $\mathrm{RNH}$ gegevens over de relatie tussen ziekten bij ouders en bij hun kinderen (5). Het was blijkbaar niet voor niets dat hij een leerling was van Frans. Huygen, de Nederlandse aartsvader van de gezinsgeneeskunde.

Onderzoeksinteressen in de geneeskunde volgen vaak een golvend patroon en een jaar of twee geleden ontstond er opnieuw interesse voor gezinsgeneeskundig wetenschappelijk onderzoek, die zich 
vertaalde in een nieuwe werkgroep. Harry was er overigens meteen bij om te helpen en te ondersteunen. Er zijn veel argumenten om de aandacht opnieuw te richten op het gezin - de kleinste, meest nabije en invloedrijke groep waarin de meeste mensen lleven. Bij ons ontstond die hernieuwde interesse uit de resultaten van het onderzoek rond multimorbiditeit. In de dagelijkse praktijkvoering valt het steeds weer op hoe sommige mensen precies de ene ziekte op de andere stapelen, terwijl anderen nooit of slechts incidenteel ziek zijn. Onderzoekers noemen dit multimorbiditeit als zij kijken naar het geheel van alle tegelijkertijd aanwezige aandoeningen of comorbiditeit als het gaat om de relatie van één welbepaalde ziekte met andere ziekten. Uiteraard heeft deze indruk te maken met het ziektegedrag van de mensen: sommigen zullen voor een verkoudheid een arts raadplegen terwijl anderen dit slechts doen als zij nauwelijks nog anders kunnen. Uiteraard zijn er ook aandoeningen die als het ware in een ketting elkaar veroorzaken. Mensen met diabetes hebben zo een hogere kans op allerlei aandoeningen dan andere mensen, vooral als die diabetes niet optimaal geregeld is. De indruk blijft echter dat hiermee niet alles verkllaard is en dat de verschillen in vatbaarheild voor allerhande ziekten blijven bestaan. Het onderzoek hier rond heeft geleid tot het proefschrift van Marjan Van den Akker en tot een aantal onderzoekingen die daarop gevolgd zijn. Er zijn veel oorzaken gevonden die het voorkomen van multimorbiditeit elk een beetje groter maken en vele dlaarvan blijken niet beïnvloed baar. De leeftijd is daar het belangrijkste voorbeeld van. Toch bleken ook enkele, op het eerste zicht minder verwachte en minder klassieke factoren een rol te spelen. Eén daarvan was het sociaal netwerk van de mens, met in de eerste plaats diens gezin.

Welke vorm het gezin ook moge aannemen, gezinsleden vormen een belangrijk onderdeel van het sociaal netwerk van mensen. Er zijn drie belangrijke manieren waarop familieleden invloed op elkaars gezondheid uitoefenen (6): genetisch, gedragsmatig en

psychosomatisch. Door genetische transmissie wordt gezondheid direct beïnvloed.

De gedragsmatige invloed die familieleden hebben op elkaars 
gezondheid bestaat vooral uit het overnemen of ondersteunen van bepaalde gedragingen. De psychosomatische invloed, omvat het 'familie-klimaat'. Zo kan stress in de familie de emotionele toestand van gezinsleden veranderen, wat vervolgens kan leiden tot biologische veranderingen in het centraal zenuwstelsel en het neuroendocriene systeem, welke predispositie voor ziekte kunnen veroorzaken.

Gezinsleden helpen elkaar bij het voorkómen van en het omgaan met ziekte (7). Tevens hebben zij invloed op de mate van therapietrouw in geval van behandeling. Recent vonden wij bij onderzoek, waar ook Harry Crebolder bij betrokken was, dat mensen die in hun gezinsleven minder betrokkenheid (cohesie) ervaren, minder kans blijken te hebben op het krijgen van bijwerkingen van geneesmiddelen (8). Dit zou samen kunnen hangen met een geringere bewustwording van lichamelijke signalen in het algemeen of een nonchalantere manier van omgang met die signalen. Een andere verklaring zou echter een geringere therapietrouw kunnen zijn. Wie zijn medicatie niet neemt, heeft ook minder kans op nevenwerkingen. Zo heeft onderzoek bij diabetespatiënten uitgewezen dat een sterke gezinscohesie en weinig conflicten tussen gezinsleden onderling, samengaan met een betere metabole controle en naleving van behandelingsvoorschriften $(9,10)$.

Bij behandeling van verhoogde bloeddruk (chronisch), hartinfarct (acuut), psychosociale problemen of crisissituaties is de betrokkenheid van de familie essentieel in de behandeling. Zo is uit verschillende onderzoeken gebleken dat de manier waarop partners in een huwelijk met elkaar omgaan rechtstreeks samenhangt met cardiovasculaire reactiviteit, welke weer gerelateerd is aan kwetsbaarheid voor cardiovasculaire aandoeningen (11). Momenteel loopt in onze groep in samenwerking met collega Falger een onderzoek waarbij mensen met een ernstig cardiaal incident (infarct of een invasieve cardiale behandeling) en hun partners bevraagd en in de tijd gevolgd worden in een poging om zicht te krijgen op de wisselwerking tussen de evolutie na het incident enerzijds en de gezinsrelaties anderzijds. 
De studie van interacties binnen gezinnen is niet eenvoudig. Idealiter zou men deze interacties moeten kunnen observeren, maar dit is een zeer arbeidsintensieve, voor de mensen belastende en tijdrovende manier van onderzoek. Bovendien zou een dergelijke observatie wellicht zelf de gepresenteerde interacties beïnloeden (Hawthorneeffect). Als een "second best" oplossing zijn vragenlijsten ontwikkeld die worden ingevuld door de gezinsleden zelf. Voorlopig hebben ook wij, een beetje tegen ons hart in, gekozen voor deze benadering.

De wisselwerking van de relaties tussen gezinsleden enerzijds en het ontstaan of de evolutie van ziekte en gezondheid van de gezinsleden anderzijds is een boeiend en belangrijk terrein van onderzoek. Wellicht de belangrijkste manier waarop gezinsleden elkaars gezondheid beinvloeden is echter het doorgeven van genetische kenmerken door ouders aan hun kinderen. Het genetisch onderzoek heeft de laatste jaren een hoge vlucht genomen. De publicatie van het menselijk genoom is daarvan de culminatie bij uitstek geweest. Het is overigens een enorm werk geweest. Een typiste die het hele genoom van Harry Crebolder zou willen uittypen en dagelijks acht uur zou werken, zou daar 50 jaar voor nodig hebben. Indien zij dat daarna ook zou willen doen voor Emma, Harry's vrouw, zou dat overigens een heel stuk sneller gaan. Niet omdat Emma zoveel minder complex zou zijn, maar omdat $99.9 \%$ van het genoom van twee mensen gelijk is.

De verschillende genen zijn (grotendeels) beschreven en van een aantal genetische kenmerken is ondertussen de relatie vastgelegd met aandoeningen die er aan gerelateerd zijn. De verschillen in het genetisch patroon tussen mensen die leiden tot het feit dat iemand blauwe of bruine ogen heeft, maar die ook aanleiding kunnen geven tot het ontstaan van ziekte noemt men polymorfismen. Genetici hebben het vaak ook over Snips (SNP's of single nucleotide polymorphisms). Goed gekend zijn bijvoorbeeld twee verschillende polymorfismen van het BCRA Vrouwen met dit polymorfisme hebben een heel grote kans op het ontstaan van borstkanker. Gelijkaardige relaties worden gevonden tussen een steeds groeiend aantal aandoeningen en de polymorfismen die eraan te grondslag liggen. 
En toch, voor de dagelijkse praktijkvoering van de huisarts moet het eigenlijk allemaal nog beginnen. De ziekten die rechtstreeks het gevolg zijn van één polymorfisme zijn uiteindelijk relatief zeiden. De kans op het ontstaan van borstkanker tijdens het leven van vrouwen met een BCRA polymorfisme ligt tussen 35 en $85 \%$ (12), wat hoog is. Maar van alle borstkankers wordt slechts $1.8 \%$ in relatie gebracht met een dergelijk polymorfisme. Voor de meeste huisartsen is dit dus iets waar zij slechts zeer zelden mee geconfronteerd worden. Voor de meeste andere aandoeningen die rechtstreeks veroorzaakt worden door één polymorfisme geldt in grote lijnen hetzelfde.

Er is een andere kant aan deze ontwikkelingen, die de huisartsgeneeskundige praktijkvoering op termijn wel eens veel ingrijpender zou kunnen beïnvloeden. Van de belangrijkste chronische aandoeningen is bekend of wordt vermoed dat zij een genetisch substraat hebben. Het verband tussen een polymorfisme dat daarbij een rol speelt enerzijds en de betrokken ziekte anderzijds is echter niet rechtstreeks en allesbehalve eenvormig. Wij komen hier volop in de wereld van de interacties. Een polymorfisme kan pas actief worden als een tweede polymorfisme ook aanwezig is of juist omgekeerd: de werking van het ene kan door het andere geblokkeerd worden. Of, een polymorfisme kan op zichzelf geen ziekte veroorzaken, maar enkel zijn invloed uitoefenen als of in de mate dat er tegelijkertijd andere, externe factoren actief zijn: Wij spreken hier over de wereld van de gen-omgeving interacties. Van blaaskanker is bekend dat het vaker voorkomt bij mensen die men snelle acetyleerders noemt, wat terug te voeren is tot een genetische variant. Tegelijkertijd is echter bekend dat deze kanker gerelateerd is aan beroepsblootstelling aan een aantal producten. Recent is op basis van onderzoek gesuggereerd dat tussen beide een sterke interactie zou bestaan. Voor prostaatkanker wordt er gedacht aan interacties tussen genetische determinanten en factoren in de voeding. Prostaatkanker is in onze streek de meest frequente kanker bij mannen. Gelijkaardige hypothesen ontstaan er voor het ontstaan van diabetes en voor harten vaatziekten. Als dit allemaal ontrafeld wordt zal zulks consequenties hebben voor heel veel mensen, want dan gaat het om 
de meest frequente ziekten en de meest frequente doodsoorzaken waarmee wij geconfronteerd worden.

Maar het gaat verder. Deze informatie zal niet enkel consequenties hebben voor de epidemiologie en wellicht voor de diagnostiek. Ook de behandeling en de preventie van ziekten zullen hier sterk door beïnvloed worden. Op dit ogenblik geven wij mensen de raad niet te roken en de hoeveelheid vet in de voeding te beperken. ledereen kent mensen die in perfecte gezondheid erg oud worden terwijl zij bekend staan als forse sigarettenrokers of een heel vetrijk voedingspatroon hebben. Betekent dit dat onze adviezen fout of overdreven zijn? Waarschijnlijk niet. Onze adviezen zijn gebaseerd op zorgvuldig onderzoek in grote groepen mensen. Wellicht is het echter zo dat er in onze bevol king een grote groep mensen is met een genetische constitutie die maakt dat bijvoorbeeld vetrijk eten een belangrijke risicofactor is, maar er zijn ook mensen voor wie dit, omwille van een verschillende genetische constitutie, niet of veel minder belangrijk is. In het Immidiet onderzoek, waaraan ook meegewerkt wordt door epidemiologen van de UM, wordt gekeken naar de interactie tussen een aantal genetische polymorfismen enerzijds en leefstijlkenmerken, vooral de voeding, anderzijds in het ontstaan van onmiddellijke riscicofactoren voor hart- en vaatziekten bij koppels in Italië, Vlaanderen en Engeland en bij koppels waarvan één partner een Vlaming is en de andere een Italiaanse immigrant (13). Wij zijn op zoek naar de mate waarin genetische kenmerken, dieet en de interactie tussen beide een verklaring kunnen vormen voor de sterk verschillende incidentie van hart- en vaatziekten tussen noord en zuid Europa. Misschien zullen huisartsen over tien of twintig jaar aan sommige van hun patiënten op goede gronden een vetarm dieet aanbevelen, terwijl zij daar bij anderen op even goede gronden zedig over zullen zwijgen.

Een ander aspect van gen-omgeving interacties met directe praktische gevolgen voor de praktijkvoering ligt in de farmacoepidemiologie. Sommige geneesmiddelen zijn enkel actief in aanwezigheid van een bepaalde genetische achtergrond. Voor andere geneesmiddelen geldt dat genetische kenmerken van de patiënten 
consequenties hebben voor de correcte dosering. Zo gebeurt op dit ogenblik veel onderzoek naar de relatie tussen RAS polymorfismen en de behandeling van hypertensiepatiënten. Wellicht is het zo dat sommige patiënten met hypertensie beter gebaat zijn met ACEinhibitoren en anderen met andere categorieën van geneesmiddelen. Maar ook voor het regelen van een antistolbehandeling hebben genetische kenmerken soms belangrijke consequenties. Het zal niet zo lang meer duren eer ons voorschrijfgedrag hierdoor rechtsreeks beinvloed zal worden.

Het is logisch dat het onderzoek naar deze problematiek ontstaan is in de wereld van de genetici en van de superspecialisten op de verschillende deelterreinen. Een gevolg daarvan is dat dit onderzoek hoofdzakelijk gebeurt in erg geselecteerde populaties en niet in de algemene bevolking. In een eerste benadering heeft alleen dergelijk onderzoek voldoende contrast om verschillen aan te tonen tussen mensen met en zonder een bepaald kenmerk. Als de evolutie van de klinische epidemiologie, met name in de diagnostiek, ons tijdens het laatste decennium echter iets geleerd heeft, dan is het wel dat de vertaling van onderzoeksresultaten uit dergelijke geselecteerde populaties naar de dagelijkse praktijkwoering in de gewone bevolking nog een hele stap is. Er ontstaat progressief grotere behoefte aan onderzoek naar de effecten van gen-omgeving interacties in de normale, niet geselecteerde bevolking. Onder meer in Engeland heeft men dit goed begrepen. Momenteel worden daar door de Medical Research Council (MRC) en de Wellcome Trust belangrijke financiële middellen vrijgemaakt voor de Biobank UK, een grootschalig register waarin gegevens over 500 .000 mensen zullen opgenomen worden (14). De centrale doelstellingen zijn het onderzoek naar de relatie tussen genetische kenmerken en het ontstaan van allerhande ziekten, het bestuderen van de spreiding van genetische kenmerken in de bevolking en het onderzoek naar gen-omgeving interacties in het ontstaan van ziekten. Engeland is een heel eind van hier en 500,000 mensen in kaart brengen en opvolgen is een enorme onderneming. Landen als Nederland en Belgie zijn hier te klein voor... Tenminste ... Is dat wel zo?

In het RNH zijn momenteel een kleine 100.000 mensen geincludeerd, 
waarvan een beperkt, aantal achtergrondkenmerken bekend zijn en waarvan de probleemlijsten zorgvuldig bijgehouden worden. De know-how en de ervaring woor het beheer van dergelijke complexe databanken en voor het uitvoeren van multivariate retrospectieve cohortstudies op basis van dergelijke registers zijn aanwezig. In het $\mathrm{RNH} 2$ dat momenteel in opbouw is, worden daarenbowen leefstijlkenmerken geregistreerd die bekend staan als mogelijke risicofactoren voor ziekte. Alleen lichaamsmateriaal wordt nog niet verzameld. De sprong naar het verzamelen en bewaren van lichaamsmaterialal voor genetische analysen brengt belangrijke technische problemen mee en heeft consequenties in de wereld van de betekenissen. Ik kan daar hier niet over uitweiden, maar ik wil die zeker niet opzij schuiven. Toch lijkt het alsof hier een perfect voorbereide akker klaarligt die erop wacht om beplant en later geoogst te worden. Alles lijkt erop te wijzen dat het onderzoek naar gen-omgeving interacties en hun effect op het ontstaan en de behandeling van ziekten één van de belangrijkste en boeiendste onderzoeksterreinen van de volgende jaren wordt. Het zal een gebundelde inzet vergen van velerlei deskundigheden, maar er is niets dat er op wijst dat het niet mogelijk zou zijn en de potentiële opbrengst in relevante medische kennis zou wel eens enorm kunnen zijn.

Harry zal in deze nieuwe ontwikkelingen als huisarts of als onderzoeker wellicht geen actieve rol meer spelen. Het moet hem echter ongetwijfeld plezier doen vast te stellen hoe het onderzoek naar aspecten van het samenleven van mensen binnen gezinnen zich verder ontwikkelt, zij het in richtingen die hij, toen hij 25 jaar geleden zijn proefschrift schreef, wellicht niet kon vermoeden.

\section{Literatuur}

1. Smits AJ, Huygen FJ. Huisarts en gezin. Utrecht: Bunge, 1986.

2. Buntinx $F(E d)$. Huisarts en gezinsproblemen. Leuven: ACCO, 1987.

3. Young RF. Elders, families and illness. I Ag Stud 1994; 8: 1-15.

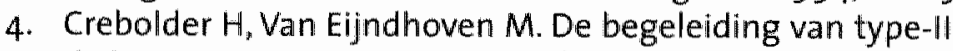
diabeten. Huisarts Wet 1986; 29 (H\& P 10): 16-19. 
5. Van der Horst FG, Metsemakers JFM, Crebolder HFJM, Franssen GHLM. Een kind met een gezondheidsprobleem: meer gezond heidsproblemen bij de ouders? Huisarts Wet 1992; 35: 503-506.

6. Papadopoulos $L$. The impact of illness on the family and the family's impact on illness. Counselling Psychology Quarterly 1995; 8(1): 27-34.

7. Voorn TB. Het gezin van de chronische patiënt. Medisch Contact 1986; 41: 1312-1315.

8. Hoek M, Buntinx F, Van den Akker M, et al. Gezinsklimaat en het voorkomen van ziekte. Tijdschr Geneesk 2002: in press.

9. Edelstein J, Linn MW. The influence of the family on control of diabetes. Social Science and Medicine 1985; 21: 541-544.

10. Safyer AW, Hauser ST, Jacobson AM, Bliss $\mathbb{R}$. The impact of the family on diabetes adjustment: a developmental perspective. Child and Adolescent Social Work Journal 1993; 10: 123-140.

11. Brown PC, Smith TW, Benjamin LS. Perceptions of spouse dominance predict blood pressure reactivity during marital interactions. Annals of Behavioral Medicine 1998; 24(4): 294-301.

12. http://www.cancer.gov/cancer_information

13. lacoviello L, Arnout J, Buntinx $F$, et al. Dietary habit profile in European communities with different risk of myocardial infarction; the impact of migration as a model of gene-environment interaction. The Immidiet study. Nutr Metab Cardiovasc Dis 2001; 11 (suppl to $\mathrm{N}^{\circ} 4$ ): 122-126.

14. http://www.biobankcom.com/concept.html

Prof. Dr. F. Buntinx is hoogleraar huisartsgeneeskunde aan de Katholieke Universiteit Leuven en hoogleraar klinische epidemiologie in de eerstelijns geneeskunde aan de Universiteit Maastricht. 


\section{Mensen met mogelijkheden}

Bert Schadé.

\section{Inleiding}

Een universitaire afdeling Huisartsgeneeskunde heeft naast onderwijs, onderzoek en opleiding ook een laboratoriumfunctie voor maatschappelijke dienstverlening. Binnen zo'n afdeling moet er een open oog zijn voor nieuwe ontwikkelingen in de gezondheidszorg en men moet worden geprikkeld deze te onderzoeken. Door deze wetenschappelijke onderbouwing maakt men de sterke en zwakke kanten zichtbaar en geeft handen en voeten aan de noodzaak, de werkzaamheid en aan de doelmatigheid daarvan. Een van de ontwikkelingen in de gezondheidszorg die de laatste jaren in snel tempo binnen het bereik van de huisarts en de huisartsgeneeskunde is gekomen is de zorg voor mensen met een verstandelijke handicap.

\section{Zorgontwikkeling}

In de vijftiger en zestiger jaren van de vorige eeuw kende de opvang van mensen met een verstandelijke handicap grof geschetst twee vormen. Mensen met een lichte verstandelijke handicap bleven thuis en waren vaak goed geïntegreerd in buurt, dorp of gehucht. Deze groep was niet altijd te identificeren omdat de gemeenschap vooral op het platteland deze mensen als volwaardige deelnemer beschouwden. Voor hen bestond er geen handicap. Daarnaast waren er grotere instellingen, vaak geleid door religieuzen, voor de opvang van mensen met een matige, ernstige tot zeer ernstige handicap. Deze voorzieningen waren speciaal daarvoor gesticht dan wel een afdeling bij een valk gesloten opvang van mensen met psychiatrische problemen. Mensen met een ernstige verstandelijke handicap werden van de buitenwereld afgeschermd. In de zeventiger jaren, mede op gelelde van de democratiseringsgolf in de psychiatrie werden voor mensen met een verstandelijke handicap kleinschaliger woonvormen gezocht. Het waren met name de ouderverenigingen die hierin het voortouw namen. Omdat men gelijk met de woonvorm ook zorg nodig had, werden deze gezinsvervangende tehuizen, overigens vaak 
nog voor 24,48 of nog meer personen, dicht tegen de grote intramurale instellingen aangebouwd. In de jaren daarop begon men geleidelijk aan de bewoners meer en meer aan te spreken op hun zelfstandigheid. Van geestelijk gehandicapten veranderde de naam in mensen met een verstandelijke handicap of mensen met een verstandelijke beperking. De tendens tot normalisatie en integratie zetten aan het eind van de vorige eeuw in snel tempo door (het burgerschapsparadigma). Dit werd nog bevorderd door het invoeren van het Persoonsgebonden Budget (PGB). Voorheen kregen mensen met een verstandelijke handicap zorg in natura (zorg èn huisvesting binnen één AWBZ-voorziening en als dat noodzakelijk was voor de matig tot ernstig verstandelijk gehandicapten ook voor de dagopvang of voor begeleid werken). Het Persoonsgebonden Budget geeft het geld niet aan instellingen maar aan de betrokkenen zelf om zorg in te kopen. Er is daarbij sprake van scheiden van wonen, zorg, werken en vrijetijdsbesteding. De zorg wordt ingekocht met behulp van het PGB. Los van de zeer moeizame start, de grote mate van bureaucratie en de cliënt-onvriendelijke procedures zet dit in de zorg een nieuwe tendens. De mensen met een verstandelijke handicap en hun belangenbehartigers gaan zelf op zoek naar de gunstigste vorm van wonen en zorg. Dit gekoppeld aan het streven naar integratie en normalisatie, uitgaande van een zorgsysteem dat wordt samengevat als community care, leidt dat ertoe dat mensen met een verstandelijke beperking steeds meer in kleinschalige woonvormen, in een gewone wijk gaan wonen; in gezinsvervangende tehuizen en daar waar dat mogelijk is in voorzieningen voor begeleid zelfstandig wonen. Ook probeert men gesteund door jobcoaches deze personen in een normale arbeidssituatie te laten functioneren. De naamgeving veranderde ook: het werden de mensen met mogelijkheden, the otherwise gifted.

\section{Rol van de huisarts}

De huisarts wordt thans geconfronteerd met mensen met een verstandelijke handicap die niet meer in categoriale voorzieningen zitten maar als patiënt bij hem of haar zijn ingeschreven. Dat was in 
de beginfase wennen. In feite waren de mensen met een verstandelijke handicap uit het zicht van de huisarts verdwenen. Als gezinsarts had de huisarts wel weet van hun bestaan omdat hij/zij meestal wel betrokken was bij het acceptatieproces nadat iemand met een verstandelijke handicap in het gezin was geboren. Ook de processen van integratie binnen het gezin gingen aan de huisarts niet voorbij. Naast adviezen over vragen over de mogelijke oorzaak dan wel advies over de wijze waarop dit in de toekomst eventueel kan worden voorkomen, kan de huisarts worden geconfronteerd met schuldgevoelens, vaak versterkt door onuitgesproken of zelfs uitgesproken verwijten van buren, kennissen, vrienden en familie. Als de diagnose snel na de geboorte, in het eerste levensjaar, wordt bevestigd, is er onzekerheid over de behandeling, de prognose en de consequenties. Gevoelens van schaamte, boosheid, wanhoop. zelfmedelijden en angst voor herhaling wisselen elkaar af en geven aanleiding tot veel vragen. De ouders gaan vaak door een fase van rouwverlies van een verondersteld "normaal" gezond kind en moeten hun toekomstverwachtingen bijstellen. Aan hullpverleners is over het algemeen geen gebrek, wel aan coördinatie en vaak een goede communicatie. Een kans voor de huisartsen die deze in het verleden vaak lieten liggen. De ouders krijgen veel goed bedoelde maar ook hier en daar tegenstrijdige adviezen. Dit leidt tot verwarring. Toch ziet men veelal dat in het gezin snel het gevoel ontstaat dat toch niet zo slecht af is als men aanvankelijk dacht. Het gezin en de sociale omgeving past zich meestal aan de nieuwe situatie aan. Men beseft al snel dat ze niet voor een gehandicapt kind hebben gekozen maar dat ze zich er ook niet voor hoeven te schamen. Over het algemeen zien we dat de acceptatie van mensen met een verstandelijke handicap door de maatschappij toeneemt.

De huisarts werd met deze problematiek geconfronteerd, maar het kind met een verstandelijke handicap zag hij/zij zelden. Heel snel na de geboorte sloot zich een circuit van hulpverleners om het kind: de kinderarts, de klinisch geneticus, het maatschappelijk werk, de sociaal-paedagogische dienst etc. Als het kind naar een medisch kinderdagverblijf ging of naar een ZMLK-school werd het aantal hulpverleners nog groter. Het kind werd in feite van de huisarts 
afgeschermd. Het hulpverlenerssyndroom, waarbij men voortdurend hulp verleent ter wille van het hulpverlenen, dreigde.

De huisarts werd als het kind opgroeide er vaak dan pas mee geconfronteerd als het gezin niet (altijd) even harmonieus op de situatie reageerde. Hoewel er vaak door mensen van pedagogische diensten gerichte begeleiding wordt gegeven, is er geen handleiding te maken over de wijze waarop men met elkaar moet omgaan. Een evenwichtige gezinssituatie zal tot stand komen met vallen en opstaan. Het gezin is immers een dynamisch systeem dat steeds weer op een andere wijze reageert. Dit komt vooral tot uiting wanneer het kind al of niet op jong volwassen leeftijd ergens anders gaat wonen. Dan worden de onderlinge verhoudingen sterk aangesproken. Ook dan nog werd de huisarts meestal indirect via de familieleden geconfron teerd met de persoon met de verstandelijke handicap. Nu wordt het anders. Mensen met een lichte tot matige verstandelijke handicap zijn op naam van de huisarts ingeschreven; ze wonen dichtbij en maken gebruik van de laagdrempelige toegang. $\mathrm{Er}$ vindt altijd een belangrijke omslag plaats rond het achttiende jaar. Het kind verdwijnt uit het hulpverleningssysteem van de kinderarts, de kinderneuroloog en de jeugd-SPD en komt dan in het veld van de veel meer gesegmenteerde gezondheidszorg voor volwassenen met andere hulpverleners en andere voorzieningen. Juist dan kan men een beroep gaan doen op de huisarts, als de betrokkene nog thuis woont maar zeker ook als het, meestal enige jaren later, begeleid zelfstandig woont of in een kleinschalige woonvoorziening verblijft. De huisarts wordt dan geconfronteerd met klachten waar hij/zij weinig ervaring mee heeft. Dat is door Henny Lantman in haar proefschrift: "Health problems in people with intellectual disability" goed in kaart gebracht. (1) Uit haar onderzoek blijkt dat aandoeningen van mensen met een verstandelijke handicap voor een deel samenhangen met de aard van de handicap, zoals zintuigstoornissen, epilepsie en motorische problemen en dat er aandoeningen zijn die specifiek met de levensomstandigheden van mensen met deze handicap te maken hebben. Een deel van deze specifieke problemen vraagt om toegesneden secundaire preventieve activiteiten (met name voor de visus- en gehoorstoornissen). Sommige aandoeningen kunnen met de 
"routine" huisartsgeneeskundige kennis met hier en daar specifieke nascholing door de huisarts zelf worden aangepakt. Andere problemen daarentegen zijn zo specifiek, dat daar vanuit medisch, psychologisch of maatschappelijk oogpunt specialistische hulp voor moet worden gezocht. Dit is een nieuwe ontwikkeling die een uitdaging vormt voor de huisarts en voor de artsen voor mensen met een verstandelijke beperking.

\section{Samenwerking}

Vooreerst moet worden genuanceerd dat als vanzelfsprekend alle mensen met een verstandelijke handicap in normale woonwijken wonen. Een overmatige tendens naar maatschappelijke integratie verscherpt het onderscheid. Dit werd al krachtig uitgedrukt door Van Liefland in 1959, die sprak over de debiliserende werking van de maatschappij. Hoe meer en deskundiger zorg wordt verricht, hoe meer men ook weer neigt tot segregatie. Het onderscheid tussen mensen die gemakkelijk kunnen integreren in de maatschappij en diegenen die daar meer moeite mee hebben (ernstig verstandelijk gehandicapten, meervoudig gehandicapten, mensen met psychiatrische comorbiditeit, met autisme, met gedrags stoornissen of andere aandoeningen) wordt groter. Hoe gewoner een mens met een verstandelijke handicap wordt behandeld, des te problematischer wordt voor anderen het feit dat ze zich niet kunnen aanpassen en dat ze bijzondere voorzieningen nodig hebben. Inge Mans omschreef dit zo: "Tegenwoordig heten zwakzinnigen mensen met een verstandelijke handicap en will men hen zoveel mogelijk behandelen als gewone en gelijkwaardige individuen. De toevoegingen "met een verstandelijke handicap" en "zoveel mogelijk" wijzen er echter op dat zwakzinnigen niet helemaal gewoon gevonden worden en dat zij, hoe bedekt ook, als figuren van gebrek worden gezien". (2) De tweedeling in de zorg die daardoor dreigt, kan nu worden overbrugd. Met aan de ene kant de huisarts en aan de andere kant de arts voor mensen met een verstandelijke handicap (AVG). Deze laatste beroepsgroep heeft de afgelopen jaren een snelle ontwikkeling doorgemaakt. Ze zijn merendeels werkzaam bij grote categoriale instellingen. Ze zijn 
erkend als medisch specialist en hebben een eigen vervolgopleiding. De huisarts weet weinig van de mensen met de grote syndromen en met extra zorgbehoeften die meestal in de intramurale voorzieningen verblijven, de arts voor verstandelijk gehandicapten zal de rol van de huisarts voor mensen met een lichte of matige verstandelijke handicap niet kunnen overnemen, al was het maar door de schaalgrootte. Het blijkt inmiddels dat beide disciplines de behoefte hebben om de gaten in de zorg die men zelf niet kan opvullen samen met de ander te dichten. Op basis van complementariteit en respect voor elkaars deskundigheid moet het mogelijk zijn dat artsen voor verstandelijk gehandicapten in de regio samenwerking zoeken met meerdere huisartsen die een aantal mensen met een verstandelijke handicap in hun praktijk hebben. Ook kunnen de AVG'ers voor de verstandelijk gehandicapten specifieke poliklinieken houden waarin ze op consultatieve basis de huisarts bijstaan in de zorg, dan wel op basis van verwijzing deze zorg tijdelijk overnemen. Dit laatste wordt op dit moment in experimentele zin onderzocht waarbij inmiddels al is gebleken dat de muren van het verzekeringssysteem voor een dergelijke samenwerking nog erg hoog zijn. Deze bijzondere ontwikkeling in de zorg heeft grote behoefte aan wetenschappelijk onderzoek zowel naar de aard van de klachten van mensen met een handicap, naar de kwaliteit van de zorg voor deze mensen alsmede naar verschillende vormen van samenwerking. Dit moet een stevige onderbouwing geven aan nieuwe vormen van zorg voor mensen met mogelijkheden.

\section{Slotopmerking}

Harry Crebolder heeft deze ontwikkelingen in de zorg voor mensen met een verstandelijke handicap voorzien. Dat hij daarbij de categorale zorg van de arts voor verstandelijk gehandicapten complementair maakt aan de meer generalistische zorg van de huisarts is bewonderenswaardig. Hij heeft op tijd ingezien dat deze nieuwe vorm van hulpverlenen niet alleen met woorden maar ook met daden in de vorm van wetenschappelijk onderzoek en zorginnovatie moet worden onderbouwd. 
Het lag voor het grijpen en Harry Crebolder is een van de weinigen die het echt stevig hebben vastgepakt en anderen weten te stimuleren om deze ontwikkeling handen en voeten te geven.

Mensen met een verstandelijke handicap, hun familie, hun belangenbehartigers en alle mensen die in deze zorg werkzaam zijn, zijn hem daar dankbaar voor.

Harry, van de ene ervaringsdeskundige tot de andere ervaringsdeskundige: "Goed gedaan jochie!".

\section{Literatuur}

1. Schrojenstein Lantman-de Valk $\mathrm{H}$. Health problems in people with intellectual disability. Aspects of morbidity in residential setting and in primary health care. Proefschrift Universiteit Maastricht 1998

2. Mans I. Zin der zotheid. Vijf eeuwen cultuurgeschiedenis van zotten, onnozelen en zwakzinnigen. Proefschrift Universiteit Utrecht. Amsterdam: Uitgeverij Bert Bakker, 1998

Prof.dr. E. Schadé is hoofd Afdeling Huisartsgeneeskunde en voorzitter van de Divisies Public Health, Klinische Methoden en Informatie van het AMC-UvA. 


\section{De patiënt, zijn gedaanten, en de vraag}

André Knottnerus.

\section{Inleiding}

in iedere beschouwing over de gezondheidszorg komt vroeg of laat naar voren dat, hoe alles ook zij, de patiënt en diens vraag centraal staan. Dat is ook zo, maar daarmee is lang niet alles gezegd. Want wie is 'de patiënt' en wat is zijn vraag? Eenduidige antwoorden op deze vragen zijn moeilijker te geven dam men op het eerste gezicht zou zeggen. Sterker nog, het antwoord is niet eenduidig.

Deze bijdrage bespreekt de verschillende gedaanten van de patiënt wat daarvan de consequenties zijn, en hoe het verder kan gaan.

\section{De $2 \times 2$ tabel van de patiënt}

Medische wetenschappers, vooral epidemiologen, maken graag gebruik van de zogenaamde $2 \times 2$ tabel. De $2 \times 2$ tabel geeft het verband weer tussen twee variabelen (bijvoorbeeld geslacht en een welig tierende haardos) die elk in twee categorieën zijn in te delen (bijvoorbeeld man/vrouw en welig/niet-welig). Als je erin slaagt een situatie zo te beschrijven dat deze past in een $2 \times 2$ tabel, kun je allerlei aspecten van die situatie beter begrijpen, en bijvoorbeeld gemakkelijk zien dat onder mannen een welig tierende haardos veel zeldzamer is dan onder vrouwen. Epidemiologen zouden daarom graag de hele wereld of nog meer in een dergelijke vrij simpele weergave onderbrengen, en sommigen gaan zelfs zo ver dat ze de wereld ook zo zijn gaan zien. Maar hoe het ook zij, de $2 \times 2$ tabel kan ons vaak een eind op weg helpen.

Laten we de methode van de $2 \times 2$ tabel nu eens een keer niet toepassen op een medisch wetenschappelijk probleem, maar op de situatie van de patiënt. De onderstaande figuur is dan inzichtgevend. De bevolking kan dan in kaart gebracht worden aan de hand van twee invalshoeken:

- beschouwen we de betrokkenen individueel of collectief

- gaat het om een actuele patient (iemand die nu ziek is), of om 
iemand die niet ziek is maar natuurlijk wel ziek kan worden (potentiële patiënt).

Figuur: De patiënt in verschillende gedaanten

\begin{tabular}{|l|l|l|}
\hline $\begin{array}{l}\text { Verschijningsvorm } \\
\text { gebruiker van zorg }\end{array}$ & Individueel & Collectief \\
\hline Actueel & De zieke patiënt & $\begin{array}{c}\text { Patiëntenvereniging } \\
- \text { categoraa! } \\
- \text { algemeen } \\
\end{array}$ \\
& $\begin{array}{l}\text { Gezond persoon } \\
\text { Potentiëel }\end{array}$ & $\begin{array}{l}\text { Burgers } \\
\text { Belastingbetalers }\end{array}$ \\
\hline & & $\begin{array}{l}\text { Verzekerden } \\
\text { Politiek }\end{array}$ \\
\hline
\end{tabular}

Uit de figuur blijkt al direct dat het hier, in tegenstelling tot de situatie in de gebruikelijke $2 \times 2$ tabel in de epidemiologie, niet om elkaar uitsluitende categorieën gaat. Immers, patiënten zijn in de regel verzekerd, en patiëntenverenigingen bestaan uit patiënten. Men kan lid zijn van meer dan één patiëntenvereniging. lemand die ziek is, is daarvoor meestal gezond geweest. Burgers, meestal verzekerd, gezond of ziek, zijn wij allemaal, en de politiek hoort namens allen te spreken. Omkeerbaar is dit alles natuurlijk niet: bijwoorbeeld, hoewel iedereen wel eens klachten heeft, is lang niet iedereen is ziek. Er zijn vele patiënten die geen lid zijn van een patiëntenvereniging. En helaas zal niet iedere patiënt later weer gezond worden. We zullen nu alle vier velden van de $2 \times 2$ tabel van de patiënt bespreken 


\section{De zieke patiënt}

ledere individuele patiënt die ziek is kan altijd een concreet beroep op de huisarts doen. (1) Dat laatste gebeurt overigens lang niet altijd, omdat men in de meeste gevallen van ziekte of onwelbevinden de huisarts niet raadpleegt (2). Kennelijk vindt men vaak zelf oplossingen, en heeft de ziekte veelal een mild en gunstig beloop. Het zijn met name de patiënten die de dokter bezoeken (Feinstein spreekt in dit verband van iatrotrope klachten (3) en daarmee een beroep op de geneeskunde doen, die de basis vormen van het medisch bedrijf en de bron zijn van de meeste klinisch-wetenschappelijke kennis. De medische studie, en de opleiding van huisartsen en specialisten is vooral gericht op het adequaat omgaan met deze subpopulatie patiënten, door middel van een zo trefzeker mogelijke diagnostiek en effectieve behandeling.

\section{De patiëntenvereniging}

Patiënten die actueel aan een aandoening lijden kunnen zich, als collectivum, verenigen in een patiëntenvereniging. Ook zijn er verenigingen van ouders van kinderen met een ernstige ziekte of aangeboren afwijking. Patiëntenverenigingen kunnen gericht zijn op een bepaalde ziekte (zoals diabetes of reuma) of categorie van aandoeningen (zoals aangeboren fysieke of mentale afwijkingen), maar kunnen ook een algemeen karakter dragen (algemene patiënten-, consumenten-, of gebruikersverenigingen). Soms zijn er patiënten- of gebruikersorganisaties die zich bezighouden met de ontwikkelingen in een bepaalde huisartspraktijk of een gezondheidscentrum $(4,5)$. Patiëntenverenigingen vertegenwoordigen een bijzonder grote ervaringsdeskundigheid, een cumulatie van unieke (leer-)ervaringen van vele patiënten die een onmisbare dimensie toevoegt aan het perspectief dat de professionele zorg biedt. Zij kunnen aldus de belangen van patiënten en gebruikers, vaak ook van degenen die geen lid zijn, direct en indirect behartigen. Het is daarom een belangrijk pluspunt van de afgelopen decennia dat deze verenigingen op allerlei manieren hun invloed in de zorg hebben doen gelden. 


\section{Gezonden en toekomstige zieken}

Gezonden kunnen zich gelukkig prijzen dat zij niet lijden aan een gezondheidsprobleem dat hun pijn bezorgt, hun leven bedreigt, of hen in het dagelijks functioneren belemmert. Maar, en dat is niet pessimistisch maar realistisch bedoeld, zij weten dat ook hun gezondheid vroeg of laat te wensen over zal laten en dat de meesten ooit langer of korter patiënt zullen zijn. Aan de ene kant kunnen zij hun best doen om door gezond te leven en door gebruik te maken van preventieve zorg zo lang mogelijk gezond te blijven, terwijl zij zich aan de andere kant adequaat kunnen verzekeren om zich in te dekken tegen de kosten die het ziek-zijn met zich zullen brengen.

\section{Burgers, verzekerden en politiek: de gemeenschap}

Allen behoren tot de gemeenschap van burgers, vrijwel steeds verzekerd, en zijn gezamenlijk verantwoordelijk voor het kiezen en onderhouden van een verantwoord politiek bestuur. Het is op dit collectieve aggregatieniveau, dat de belangen van allen samemvloeien en tegelijk kunnen botsen. Samenvloeien: omdat de belangen van zowel zieken als gezonden, individueel en collectief, door de gemeenschap moeten worden behartigd. Daarbij gaat het om het creëren van optimale personele en materiële voorzieningen, en het realiseren van de organisatorische en financiële randvoorwaarden voor de best mogelijke zorg. En botsen: daar komen we nu op.

\section{Solidariteit met onszelf}

Artsen worden vaak geconfronteerd met de tegenstelling tussen het micro- en het macroniveau. Dokters zijn dokter geworden om patiënten de best mogelijk zorg te geven, niet om zich bij iedere spreekuurcontact af te vragen: deze behandeling is wel het beste wat ik beschikbaar heb voor deze patiënt, maar wellicht is deze toch te duur, doe ik een andere patiënt tekort, of raakt het budget te gauw uitgeput.

Financiële tekorten hangen in belangrijke mate samen met 
belangentegenstellingen rond ons zorgstelsel, en die tegenstellingen houden weer verband met de bovenbeschreven verschillende gedaanten van de (toekomstige) patiënt. Immers, de patiënten die ernstig ziek zijn, willen begrijpelijkerwijs graag alle mogelijke en effectieve zorg, terwijl de burgers, de verzekeraars en de politiek de kosten juist willen beteugelen. De burger en verzekerde wil een zo laag mogelijke premie en belasting betalen, maar verwachten ook verzekerd te zijn van optimale zorg zodra die nodig is. De politicus moet een goed verhaal aan de belasting- en premiebetaler kunnen vertellen als het gaat om zuinige boekhouding in de zorg, maar als zijn eigen kind ernstig ziek is wil hij als vader natuurlijk ook het beste van het beste, zonder belemmerd te worden door de politieke nachtmerrie van te hoge kosten.

Mensen die over het algemeen gezond zijn zuchten wel eens onder de financiële last die zieken hen bezorgen. Moeten zij, die de samenleving zelf zo weinig kosten, nu echt zo veel betalen voor zorggrootgebruikers? Jongeren, die gelukkig meestal vrij gezond zijn, zullen zich wel eens hetzelfde afvragen als het gaat om de hoge zorgkosten voor ouderen. En we merken voorts dat verzekerden met een hoog inkomen er dikwijls moeite mee hebben dat zij relatief fors meebetalen aan de zorguitgaven ten behoeve van hen met een lager inkomen. Om nog niet te spreken van de verschillen in erfelijke belasting wat betreft het risico op in sterke mate genetisch bepaalde aandoeningen. Veel verzekeraars denken op dit alles handig in te spelen, door goedkope verzekeringsarrangementen aan te bieden aan jongere, gezonde, 'erfelijk niet belaste' personen. Met als voorspelbaar gevolg dat de premielasten voor ouderen, zieken en 'erfelijk belasten' meer dan navenant zullen stijgen.

Hoe lastig dit alles in de praktijk ook moge zijn op te lossen, het kan helpen als wij ons twee zaken goed voor ogen blijven houden:

- Zoals eerder aangegeven gaat het in de zorg ondanks de geschetste belangenverschillen, bezien in het perspectief van het geheel, in principe steeds om dezelfde begunstigde: namelijk ons zelf. Wijzelf waren jong en worden oud, met onze kinderen zal ook zo gaan. Wie nu kerngezond is kan er morgen ernstig aan toe zijn, en de meesten zullen eens intensieve zorg nodig hebben. 
Alle aanstaande ouders kunnen onverwacht een ernstig gehandicapt kind krijgen, waarbij het leed niet vergroot moet worden door niet te dragen financiële lasten. (6) Wie geen kinderen krijgt deelt mee in de lasten van de kinderen van anderen, die dan op hun beurt weer mee betalen aan de oude dag van degenen zonder kinderen. En wat betekent het verschil tussen een hoog en een laag inkomen in de zorg nog in het licht van de enorme, door welk individu dan ook niet op te brengen, kosten van de zorg voor wie ernstig ziek wordt. De moraal is dus: degenen die solidariteit met anderen op zich nog niet vanzelfsprekend winden, dienen te beseffen dat het uiteindelijk over henzelf gaat, in goede maar ook in niet te voorspellen en altijd onwelkome slechte tijden.

- Onze voorouders hebben ons het goede voorbeeld gegeven. Vanuit het niets hebben zij] immers, met name in tweede helft van de negentiende eeuw en de eerste helft van de twintigste eeuw, een systeem van maatschappelijke solidariteit tot stand gebracht dat juist de genoemde tegenstellingen overbrugde. De essentie van de $2 \times 2$ tabel van de (toekomstige) patiënt, met de verschillende gedaanten van dezelfden, hebben zij lang geleden en onder economisch barre omstandigheden serieus genomen in het opbouwen van een sociaal-medisch verzekeringsstelsel. Laten wij anno 2002 niet wijzer trachten te zijn, en historisch geheugenverlies voorkomen. Wat in enkele jaren kan worden afgebroken, kan nog in geen decennia worden hersteld.

Gelukkig zijn er inmiddels ook allerlei manieren ontwikkeld om zonder teruggang in kwaliteit kosten te beheersen, zoals: richtlijnen voor rationele zorg, nieuwe vormen van samenwerking in de eerste lijn en met de tweede lijn (7-9), en het koersen op effectiviteit en evidencebased medicine. Maar nog steeds kunnen wij een voorbeeld nemen aan hoe onze voorouders met doelmatigheid omgingen. Terwijl de korte termijndoelmatigheid, dat wil zeggen de boekhoudkundige doelmatigheid over niet meer dan een kabinetsperiode bezien, bij berekening vooraf absoluut niet gunstig zou zijn uitgepakt voor het creëren van sociaal-medische voorzieningen, bleek de lange termijn (maatschappelijke) doelmatigheid enorm groot. Langetermijnvisie verdient het primaat boven kortetermijndoelmatigheid. En het lijkt er 
gelukkig op dat de politiek zich dit weer steeds meer bewust wordt. Waar men begin jaren negentig nog trots was dat het gelukt was om het beleidsdoel sinds de jaren zeventig te halen, namelijk het worden van een, internationaal bezien, hoogstens middenmoter wat betreft de kosten van de zorg, begint men zich daar nu juist voor te schamen. Immers, de capaciteit en daarmee de kwaliteit zijn fors achter geraakt. bij de demografische en epidemiologische ontwikkeling, en miljardenmeevallers blijken zich te ontpoppen als gecumuleerde onderinvesteringen in de zorg.

\section{Dé patiënt verdwijnt}

De gedaanten van de patiënt zijn niet statisch, maar zijn verbonden met maatschappelijke verandering en wetenschappelijke progressie. De toenemende mondigheid van burgers bracht, zowel in de spreekkamer als daarbuiten, een steviger optreden van de patiënt en patiëntengroeperingen met zich mee. De komende decennia is de belangrijkste verandering te verwachten van de zich snel binnen de gehele geneeskunde verbreidende impact van de groeiende kennis op het gebied van het menselijk genoom. Dit heeft niet alleen consequenties voor de klinische genetica in engere zin, maar zal ingrijpende gevolgen hebben voor de dagelijkse medische 'diaprognostiek' (op moleculair niveau is dit immers een geïntegreerd proces), indicatiestelling, en therapeutische en preventieve interventie (10). Ook op het gebied van preventie en voorlichting zijn de eerste tekenen van deze ontwikkeling merkbaar. Dit alles zal betekenen dat steeds vaker ook mensen die klinisch gezond zijn en voor wie er medisch geen reden is tot zorg, om persoonlijke en maatschappelijke redenen willen weten of er belangrijke verwikkelingen in hun genoom zijn vastgelegd. Ook uit preventiefoogpunt kan dit van belang zijn. Er zijn op dit gebied natuurlijk nog vele wetenschappelijke, maatschappelijke en ethische problemen, risico's en bezwaren te noemen (11-13). Deze gelden echter steeds meer als 'uitdagingen' voor wetenschap, zorg en voorlichting dan als negatief gerichte imperatieven. Al met al zal, veel meer dan dat tot nu toe het geval is in de traditionele preventieve en anticiperende zorg gericht 
op risicogroepen, het verband tussen de actuele gezondheidstoestand en de individuele hulpvraag losser worden. Kortom, de standaardpatiënt verdwijnt, in die zin dat naast de traditionele 'patiënten" in toenemende mate hulpvragers die (nog) niet ziek zijn een beroep op de medicus gaan doen. Dat zal belangrijke implicaties hebben voor het medisch onderwijs, het huisartsenvak en de opleiding daartoe, en het onderzoek in de eerste lijn.

Uit het oogpunt van maatschappelijke solidariteit bezien lijkt er in dit verband een, overigens nog te weinig voorziene, positieve ontwikkeling aan te komen. Daar waar verzekeraars, na een langdurige periode van 'eenvoudige' solidariteit de laatste jaren sterk koersen op premiedifferentiatie en voordeel- en dus ook nadeelpakketten, is te verwachten dat zij over enige tijd op hun schreden zullen moeten terugkeren. Immers, het wordt steeds duidelijker dat bij iedereen genetisch bepaalde, soms onverwacht grote, kostenveroorzakende, levensbekortende (lees de periode van premiebetaling reducerende) gebreken te vinden zijn. Systematisch zoeken ten behoeve van premiedifferentiatie (als dit al toegestaan zou worden) heeft dan bij toenemende kennis steeds minder zin, en de rationaliteit en maatschappelijke rechtvaardigheid van 'simpele solidariteit' wordt alleen maar meer vanzelfsprekend.

\section{Tot slot}

Gegeven de verschillende gedaanten van de patiënt, en de maatschappelijke veranderingen daarin, is het van groot belang dat er bakens zichtbaar blijven waarvan men op aan kan. Zo'n baken is de eerstelijnsarts, die er geen twijfel over laat bestaan dat hij staat voor degenen die een beroep om hem doen, en hen de optimale zorg wil bieden. Omdat de koers vaak moeilijk is en zelden vanzelfsprekend, zijn er inhoudelijk overtuigende gezagvoerders nodig. Harry Crebolder heeft gedurende vele decennia lief en leed gedeeld met de patiënt in al diens gedaanten, in rijke en arme delen van onze wereld. Hij is op alle niveau's van de zorg nadrukkelijk en onuitwisbaar geweest, nationaal en internationaal richtingbepalend in zorginnovatie, wetenschappelijk onderwijs en onderzoek, en academisch en 
maatschappelijk bestuur. Behalve hoogleraar ook leraar, in de eerste lijn en in de samenwerking met de tweede lijn. Een wilskrachtig gezagvoerder met veel gezag zwaait af, maar de koers is uitgezet.

\section{Literatuur}

1. Koninklijke Nederlandse Akademie van Wetenschappen. Rapport van de Subcommissie Gezondheids(zorg)wetenschappen.

Amsterdam: Commissie Geneeskunde, 1991

2. Van de Lisdonk EH. Klachten zonder klagen bij de dokter. Huisarts Wet 1988; 31: $257-60$

3. Feinstein AR. Clinical epidemiology, the architecture of clinical research. Philadelphia:WB Saunders Company, 1985.

4. Crebolder HFJM. Onderzoekingen rond het gezondheidscentrum Withuis. Criteria voor de patiënt bij de beoordeling van een gezondheidscentrum (2). Huisarts Wet 1975; 18:40

5. Crebolder HFJM. Onderzoekingen rond het gezondheidscentrum Withuis. Enige aspecten van de organisatie en werkwijze van het gezondheidscentrum - beoordeeld door de cliënten (10). Huisarts Wet 1977; 20: 301

6. Van Schrojenstein Lantman - de Valk H. Health problems in people with intellectual disability.

Academisch Proefschrift. Universiteit Maastricht, 1998

7. Vierhout WP, Knottnerus JA, van OOij A, Crebolder HF, Pop P, Wesselingh-Megens AM, Beusmans $\mathrm{CH}$. Effectiveness of joint consultation sessions of general practitioners and orthopaedic surgeons for locomotor-system disorders. Lancet 1995 Oct 14;346(8981):990-4

8. Stalenhoef PA. Falls in the elderly. A primary care-based study. Academisch Proefschrift. Universiteit Maastricht, 1999

9. Vlek JFM. Cardialogue. Joint consultation of general practitioners and cardiologists a primary care setting.

Academisch Proefschrift. Universiteit Maastricht, 2000

10. Netherlands School of Primary Research.

Progress Report 1995 -1996. Maastricht: CaRe, 1997. 
11. Gezondheidsraad. DNA-diagnostiek. Gezondheidsraad: Den Haag, 1998; publicatie $\mathrm{nr}$ 1998/11

12. Gezondheidsraad. Farmacogenetica. Gezondheidsraad: Den Haag, 2000; publicatie $\mathrm{nr} 2000 / 19$

13. Gezondheidsraad: Familiaire hypercholesterolemie en de Wet op de medische keuringen. Gezondheidsraad: Den Haag, 2001; publicatie $\mathrm{nr} 2001 / 26$

Prof. dr. J.A. Knottnerus is Voorzitter van de Gezondheidsraad in Den Haag en hoogleraar Huisartsgeneeskunde aan de Universiteit Maastricht. 


\section{T ussen gezondheidscentrum en geacademiseerde huisartspraktijk}

Chris van Weel.

\section{Eerste kennismaking}

Het was medio 1974 en de tijd drong voor de vernieuwing in de huisartsgeneeskunde, die enige jaren tevoren met het tot stand komen van de eerste gezondheidscentra was ingezet. De toekomst van de eerste lijn zou er een zijn van multidisciplinaire samenwerking, maar met het bijeenbrengen - beter misschien: beschikbaar stellen van de 'kerndisciplines' wilde het niet viotten. Een aantal angry young men, huisartsen uit de leidende centra, kwam samen in het Gezondheidscentrum Withuis in Venlo om een 'daad' te stellen: zonder deugdelijke financiering, zonder gecommiteerdheid van de beleildsmakers waren de gezondheidscentra gedoemd te mislukken. De discussie boog zich over de complexiteit die eigen was aan de materie: over de inkomensstructuur van de huisarts (met '151-max' als magische sleutelformule), de verhouding 'basispakket en AWBZ', over het wankele draagvlak in de landelijke politiek en de tegenwerking uit eigen (LHV en KNMG) kring. Eén van de deelnemers aan het overleg - de wijsheid die hij uitstraalde maakte dat zijn haardos ook toen al grijs moet zijn geweest - herleidde de problemen tot zijn ware proporties: "als het beleid om gezondheidscentra vraagt, waarom daarvoor dan ook geen gerichte financiering", zo vroeg hij zich bij voortduring af; "indien het de bedoeling is dat hulpverleners samenwerken, zorg er dan voor dàt diverse disciplines tot de gezondheidscentra toetreden!"

Het was voor schrijver dezes het begin van een dierbare vriendschap en samenwerking met Harry Crebolder. Intussen was uiteraard zijn pragmatisme te simplistisch voor het Poldermodel van de eerstelijns gezondheidszorg. De verzuilde organisaties - in de nadagen van hun macht - hielden hardnekkig de vinger op de knip en waakten er angstvallig voor dat hun wijkverpleegkundigen en maatschappelijk werkers de makke schapen bleven binnen hun eigen instelling. Voor de medische beroepsorganisaties - LHV aan kop - moest éérst de meerwaarde van gezondheidscentra maar eens aangetoond worden. De politiek maakte de gebruikelijke passen op de plaats. Het keiharde 
appèl van het Withuisoverleg maakte een zachte landing op de wolluge lappendeken van de eerste lijn. De geëiste financieringsregeling werd met een subsidie afgekocht, en de gezondheidscentra daarmee vakkundig ingepolderd. De meerwaarde van de gezondheidscentra vormde in tussen het onderwerp van het proefschrift dat Harry Crebolder voorbereidde, en waarop hij enkele jaren later bij Frans Huygen zou promoveren.

\section{Ziekenfondswet}

Met het tot stand komen van de Ziekenfondswet was Nederland het eerste land dat een primary care structuur in zijn gezondheidszorg tot stand had gebracht - luttele jaren eerder dan Groot Brittannië met de National Health bill in 1948. De wet had grote en duurzame gevolgen voor de huisarts, maar werd nauwelijks, in tegenstelling tot de NHS in het VK, beleefd als een keerpunt. De ziekenfondswet regelde de inkomsten en de toegankelijkheid van medische zorg, met daarin een centrale positie voor de huisarts. Als een 'algemene' voorziening bracht het 'alle' Nederlandse huisartsen onder één noemer, wat als belangrijk gevolg had dat de huisartsgeneeskunde tot ontwikkeling kon komen buiten het kader van verzuiling en confessionele dominantie om - dit in tegenstelling tot wijkverpleging en het maatschappelijk werk, wier betrokkenheid het bovengeschetst Withuisoverleg zo node miste. De paradoxale gevolgen hiervan waren dat de huisartsgeneeskunde zich in een maatschappelijk isolement moest ontwikkelen. Tussen 1950 en 1980 vormden psychische en sociale problemen, seksualiteit en anticonceptie de grote thema"s aan de hand waarvan de discipline zich ontwikkelde. Ook maatschappelijk waren dit in die tijd de grote thema's, maar de overige betrokken professionals opereerden nu juist binnen de gangbare verzuilde kaders - gevangenen van een eerdere wetgevende gebeurtenis, de vrijheid van religie die in de Napoleontische periode werd geintroduceerd. In de jaren zeventig van de vorige eeuw werden de resten van de Verzuiling die hieruit had geresulteerd, ontmanteld. Volksgezondheid vormde daarvoor het strijdtoneel, ten detrimente van degenen die naïef genoeg op dat toneel een inhoudelijke 
performance betrachtten. Deze historische schaduw hing sterker over het Withuisoverleg dan de deelnemers zich dat toendertijd zullen hebben gerealiseerd.

Een andere consequentie van de Ziekenfondswet lag in de beperking tot medische voorzieningen - hetgeen nu juist de door Crebolder gewenste regie over de gehele (verpleegkundige en maatschappelijke) zorg onmogelijk maakte. Hier manifesteerde zich een groot verschil met Groot Brittannië, waar gezondheidscentra en primary care teams als het ware de huisarts werden aangeboden. Verstoken van evidente faciliteiten waarin men zich kon manifesteren, betekende dit dat de huisartsen in Nederland vooral een ideeënkader - zo men wil een ideologisch kader - ontwikkelden om hun professionaliteit invulling te geven. De Woudschotenverklaring vatte het 'waartoe wij huisartsen op aarde zijn' anno 1957 op indrukwekkende wijze samen. Het vormde bestek en marsroute voor een decennium van activiteiten.

\section{Lijn in de eerste lijn- waartoe zijn wij op aarde II}

Tegen deze achtergrond vond de tweede huisartsgeneeskundige innovatie plaats, die van de multidisciplinaire samenwerking. Om psychische en sociale problemen het hoofd te kunnen bieden, bestond toenemende behoefte aan eem partnerschap met deskundigheid op dit terrein. Met de psychosociale oriëntatie werden de beperkingen van de geneeskunde gemarkeerd - "het sociale model naast of in plaats van het medische model". De speurtocht naar partners in de feitelijke zorgverlening bracht de gezondheidscentra in een positie die inmiddels genoegzaam bekend is uit het poldermodel.

De structuurnota van staatssecretaris Hendriks die de lappendeken van de eerste lijn beoogde om te vormen tot een samenhangende organische structuur, resulteerde niet in een samenhangend beleid dat de diverse disciplines daadwerkelijk samenbracht - Harry Crebolder bleef zich verbazen, en met hem velen. In plaats daarvan werden huisartsen, met in hun gevolg fysiotherapeuten, apothekers en verloskundigen ingepolderd in overleg en onderhandelingen, niet met verpleegkundigen of maatschappelijk werkers, maar met hun bazen, de directies van diverse zuilorganisaties. En bestuurderen 
waren er veel, in die periode. Zij waren zonder uitzondering verwikkeld in fusies en in een proces van schaalvergroting, de sanering in het licht van de zich aankondigende ontzuiling. De onderhandelingen rond gezondheidscentra en samenwerking vormden daarmee voor hen de laatste kans de eigen identiteit zeker te stellen - niet om de eerste lijn in zijn algemeen op een multidisciplinaire leest te schoeien. In de bezweringsformules van die onderhandelingstafel ging het er dan ook nu weer om eens aan te geven wat de lijn moest zijn in de eerste lijn. Was multidisciplinariteit inmiddels niet een achterhaalde zaak en moest het eigenlijk niet 'interdisciplinair'? Verpleegkundigen dienden in ieder geval nooit te hoeven doen wat huisartsen opdroegen, en, ja, wat was toch eigenlijk de meerwaarde van gezondheidscentra? De huisartsen met in hun spoor fysiotherapeuten, apothekers en verloskundigen beschreven nog maar eens de aan gezondheidscentra ten grondslag liggende concepten, de ideeënwereld en ideologieën, een Woudschoten II, waartoe de gezondheidscentra op aarde zijn. Maar tegen het verbale geweld van doorknede zuilen als onderhandelaars was geen kruid gewassen. Alleen waar de directe contacten tussen huisarts, wijkverpleegkundige, maatschappelijk werker en fysiotherapeut op de werkvloer vaste grond onder de voet hadden gekregen, beklijfden de intenties. Harry Crebolder scheef er, op basis van de vaste grond van het gezondheidscentrum Withuis, een prachtig proefschrift over. De meerwaarde van gezondheidscentra bleek in ruim 10 artikelen in Huisarts en Wetenschap uit te meten te zijn, of de samenwerking nu multi- of interdisciplinair moest worden gewogen.

Wat beklijfde voor de gehele discipline huisartsgeneeskunde was het raison d'etre van de gezondheidscentra. De professionele ontwikkeling van de huisarts voltrok zich daarmee op de grens van het medische model: medicalisering, ziektegedrag, probleemgedrag, preventie van somatische fixatie. De huisarts als poortwachter vervulde deze opdracht als bij uitstek de deskundige in het benoemen en labelen van menselijke problemen - een deskundigheid die werd uitgevochten in de classificatie van ziekten en problemen. Homoseksualiteit en hysterie verdwenen als ziektebeeld, sociale en maatschappelijke problemen werden toegevoegd. 


\section{Academische netwerken}

Hierin presenteerde zich de specifieke deskundigheid van de huisarts en de waarde die daarmee aan de geneeskunde werd toegevoegd. De eerste echte erkenning van buiten hiervoor kwam waar die aanvankelijk het minste werd verwacht: uit de universiteit: onderzoek van het eigen klinische domein, de eigen specialisatie-opleiding, het onderwijs over het eigen klinische domein aan medisch studenten, maar in toenemende mate de noodzaak om vanuit de huisartsgeneeskundige visie onderwijs te geven over diverse aspecten van de geneeskunde in het algemeen. De huisartsgeneeskunde werd 'geacademiseerd'. Wat in eerste instantie een kleinschalig karakter had - de Maastrichtse "eerste-lijns faculteit' vond uiteraard snel de weg naar het Venlose Withuis en naar Harry Crebolder - bleek een dynamisch proces.

De niet aflatende stuwende kracht van Harry Crebolder is daar van doorslaggevende betekenis geweest, evenals, de lezer vermoedde het al, een beschrijving van de ten grondslag liggende visie - disciplineplan HAG, het academische 'waartoe zijn wij op aarde', in de vorm van de KNAW-disciplinebeschrijving 'huisartsgeneeskunde'. Maar de resultaten zijn er naar. De acht universitaire huisartsgeneeskundige afdelingen werken inmiddels intensief samen met huisartspraktijken. Het exacte aantal is slechts te schatten maar het gaat bij iedere afdeling om (a) stafleden (circa 20 huisartsen), (b) onderzoek (ongeveer 60 praktijken), (c) co-assistentschappen (zo"n 150 praktijken), (d) het laten meelopen van medisch studenten in diverse fasen van de studie (geschat: 100 praktijken), (e) de specialisatie-opleiding (rond de 150 praktijken). Dit wil zeggen dat tegen de 3500 huisartsen betrokken zijn bij academische activiteiten op het terrein van huisartsgeneeskunde. Gevoegd bij de activiteiten van NHG. LHV en nascholing komt dit erop neer dat een ruime meerderheid van de Nederlandse huisartsen rechtstreeks bijdraagt aan de ontwikkeling van de discipline huisartsgeneeskunde.

\section{Nederland en Europa}

Dat anno 2002 de huisartsgeneeskunde er weer aan toe is om de grondslagen en het ideeën erfgoed nog eens opnieuw vast te leggen, 
zal de lezer inmiddels niet verbazen. Een nieuw element is de internationale context waarin dit plaatsvindt. De wijze waarop de Nederlandse huisartsgeneeskunde in de ziekenfondswet werd gepositioneerd maakte dat de discipline het voor zijn ontwikkeling vooral van de missie in de gezondheidszorg moest hebben. Het 'eerste geboorterecht" lijkt zich nu uiteindelijk te verdisconteren. Niet de export van een 'national health structure' staat daarin centraal, maar een met bloed zweet en tranen afgedwongen eigen 'vision' van de Europese huisartsgeneeskunde - onder het leiderschap van het NHG; een proces dat zich op mondiaal niveau waarschijnlijk kort daarna zal voortzetten. Bij het op gang komen van deze Europese discussie speelde het onderwijs-netwerk EURACT een leidende rol, het netwerk waaraan Harry Crebolder gedurende vele jaren zulke belangrijke impulsen aan gaf. Met deze Europeïsering van het omschrijven van het gedachtengoed van de huisartsgeneeskunde is de cirkel gesloten. Want op één of andere manier hangt deze ontwikkeling samen (eruit voortvloeien is misschien een lets te boude bewering) met het Withuisoverleg van al die jaren terug.

\section{Harry Crebolder, de constante factor}

De wordingsgeschiedenis van de moderne huisartsgeneeskunde is in belangrijke mate de professionele loopbaan van Harry Crebolder. Af en toe wat ongeduldig, maar met grote vasthoudendheid hield hij zicht op het grotere belang: het tot volle effectiviteit brengen van het potentieel van de huisartsgeneeskunde. Wat via de ontwikkeling van de gezondheidscentra had kunnen - en eigenlijk ook moeten gebeuren, komt nu in de academische verankering van de huisarts tot stand. Er moest veel worden getolereerd door de angry young men van weleer, toegezegde klare wijn bleek doorgaans nieuwe wijn in oude zakken. Maar uiteindelijk verlochent kwaliteit zich niet, het doorzetten van Harry Crebolder werd beloond. Harry: enorm bedankt voor je vasthoudendheid, inzet, samenwerking en vriendschap.

Prof. dr. Chr. van Weel is hoogleraar huisartsgeneeskunde aan de KUN. 


\section{Make my day}

Hans Fiolet.

De huisartsgeneeskunde is flink in beweging. Huisartsen zijn niet langer "geroepenen" die zeven maal vierentwintig uur voor alles en iedereen beschikbaar zijn. Het is een beroep geworden dat professionaliseert en zich aanpast aan de eisen van de moderne tijd. Voor de huisarts betekent dit dat de praktijk lang niet altijd meer aan huis is, dat er vaker wordt gewerkt in duoverband of in groepspraktijken, dat de diensten nu worden gedaan in een grootschalig structuur: de centrale huisartsenpost. Professionalisering geeft verder de gelegenheid tot een zekere mate van functiedifferentiatie, zeker daar waar met meerderen wordt gewerkt. Naast de doktersassistente komt er ruimte voor ondersteuning door andere paramedische werkers: waarvan de praktijkverpleegkundige een actueel voorbeeld is. Voor een belangrijk deel zijn deze ontwikkelingen vergelijkbaar met de geschiedenis van medisch specialisten: verenigd in maatschappen hebben zij de taken verdeeld, terwijl het grootste deel van de infrastructurele ondersteuning is. uitbesteed aan de ziekenhuisorganisatie: daar wordt personeel, ruimte, automatisering en wat dies meer zij geregeld. Gevolg voor de medisch specialist is dat er een hefboomwerking ontstaat, waarbij tientallen medewerkers in de ziekenhuisorganisatie ondersteunend zijn en daadwerkelijk substitueren. Vraag is of hiermee definitief de richting is bepaald die de huisartsgeneeskunde de komende jaren kan en moet gaan. Zeker is dat er belangrijke woordelen zijn te behalen uit een organisatiestructuur waarbinnen de professional zich kan toeleggen op zijn primaire taak: de patientenzorg. Maar naast overwegingen die te maken hebben met arbeidsvoorwaarden en de nu al waarneembare en nog verder afnemende instroom van jonge huisartsen, is het ook van belang dat de ontwikkeling van de huisartsgeneeskunde bepaald wordt door inhoudelijke opvattingen.

In het Nederlandse systeem heeft de huisarts immers een cruciaal andere rol dan de specialist: hij is de poortwachter. Zorg op maat en doelmatigheidsoverwegingen maken dat het overgrote deel van de problemen, waarmee patiënten komen door de huisarts wordt 
opgelost, zonder dat het komt tot een verwijzing, zonder dat de hobbel van de wachtlijst hoeft te worden genomen. Als we willen vasthouden aan deze situatie, ervan overtuigd dat dit ten opzichte van de gezondheidszorgorganisatie in de ons omringende landen belangrijke voordelen heeft, dan moet deze grondgedachte ook terug te vinden zijn in de vormgeving van de huisartsgeneeskunde van de zee eeuw. Maar dit is lang niet altijd zonder meer het geval. De zorg voor chronisch zieken, ooit een belangrijk aandachtsgebied van de huisarts wordt in het kader van diseasemanagement meer en meer overgenomen door specialisten en specialistisch verpleegkundigen. Niet alleen relatief zeldzame en complexe patiënten met een hoge behoefte aan technologische infrastructuur, zoals de dialysepatiènt, maar ook veel voorkomende patiënten: de diabetespatiënt, de patiënt met hartfalen, COPD, reuma en noem maar op, dreigen steeds verder verwijderd te raken van de huisarts. Wat ooit begon als goedbedoelde clinical outreach bedreigt meer en meer de positie van de huisarts. Niet altijel is de huisarts hierbij degene die het allemaal overkomt. Terwijl steeds meer "consumenten" er voor kiezen zich te laten behandelen op een spoedeisende eerste hulp van een ziekenhuis in plaats van door een huisarts, wordt dit nog gestimuleerd door een situatie waarin veel centrale huisartsenposten "gesloten" zijn, niet of nauwelijks samenwerken met ziekenhuizen op het gebied van patiëntenselectie en zelfs stellen dat zelfverwijzers zodanig bijdragen aan de toch al te grote werklast van de huisarts, dat zij geweerd dienen te worden uit de centrale huisartsenpost. Een centrale huisartsenpost in een functionele relatie met een afdeling Spoedeisende Eerste Hulp, zoals in Maastricht vormgegeven "is een oplossing die weliswaar de werkdruk van de huisarts tijdens de diensten verhoogt, maar in belangrijke mate tegemoet komt aan de taakopvatting van de huisarts zoals die in ons huidige bestel geldt. Voorwaarde is wel dat er een oplossing komt voor het honoreringsvraagstuk. Simpelweg stellen dat de inspanningen van de huisarts al verdisconteerd zijn in de bestaande honoreringsstructuur doet hier geen recht aan. 
Vanuit de behoefte integrale zorg te verlenen heeft de huisartsgeneeskunde in de tweede helft van de vorige eeuw, naast het meer uitgesproken medisch handelen ook een steeds belangrijkere rol gespeeld in de geestelijke en maatschappelijke dienstverlening. Dit is zover gegaan dat, met het wegvallen van eerdergenoemde medische behandeldoelen velen zich nu afvragen of dit niet leidt tot een situatie dat de huisarts voornamelijk nog geconfronteerd wordt met problemen waar hij niet of niet in de eerste plaats voor is opgeleid en die zo sterk verweven zijn met maatschappelijke fenomenen dat ze voor hem of haar ook niet oplosbaar zijn. Competenties en behandeldoelen lopen hier meer en meer uiteen. Het alleen veranderen van de opleidingsstructuur of het vergroten van de capaciteit van de opleiding kan weliswaar bijdragen aan de potentiële instroom, maar een sterker focus op de huisartsgeneeskunde als een in de eerste plaats medische discipline kan mogelijk evenzeer motiverend werken en een groter aantal basisartsen laten kiezen voor een carrière als huisarts

Ik schets, hier en daar misschien wat ongenuanceerd, een beeld van de huisartsgeneeskunde, dat gekenmerkt wordt door dilemma's en bijna autonome ontwikkelingen. In die situatie bestaat er niet alleen behoefte aan pragmatici en korte termijndenkers, maar is het van groot belang dat er ook beroepsuitoefenaars en deskundigen zijn die tegen de verdrukking in zich blijven concentreren op ontwikkelingen die recht doen aan de oorspronkelijke dóelstellingen van de huisartsgeneeskunde en vanuit een situatie die zij benoemen "als een blessing in disguise" gebruik maken van de ruimte om nieuwe wegen in te slaan, waarmee in de eerste plaats de patient wordt gediend. maar die ook de positie van het vak kunnen versterken. Zulke mensen zijn zeldzamer dan je op het eerste gezicht zou denken. Het vraagt niet alleen om een combinatie van inspiratie en enthousiasme, maar ook om doorzettingsvermogen en altruisme. Het is niet altijd eenvoudig om tegen de waan van de dag in te gaan, het bestaan van formele en bureaucratische relaties te negeren, zonder daardoor zelf in hoge mate gefrustreerd te raken en de bereidheid te verliezen een luisterend oor te blijven bieden aan degenen die vaak al in eerste 
termijn weten waarom jouw idealen het moeten afleggen de wetten van macht, budget en behoudzucht. Het vraagt om een doordacht strategisch inzicht dat voorkomen moet dat alle inspanningen leiden tot de positie van een roepende in de woestijn, of die van een profeet die in eigen land...., enfin, $U$ weet het wel.

Komend vanuit de soms rechtlijnige gedachtewereld van het management van de ze lijn, waar de betekenis van de huisartsgeneeskunde veelal wordt onderschat en waar het gebrek aan zichtbare organisatorische structuren binnen de re lijn vaak (onterecht) wordt beschouwd als een bewijs voor de ondergeschikte positie ten opzichte van de ziekenhuisorganisatie, heb ik mij de afgelopen twee jaar mogen concentreren op het versterken van de relaties tussen juist die 1e en ze lijn, daarbij geholpen door bestuurders die tot het inzicht waren gekomen dat samenhang en een besef van complementariteit in de zorgketen onvoorwaardelijke eisen zijn om de zorg op een hoger niveau te brengen. Niet alleen voor het ziekenhuis van de 21e eeuw is dit een belangrijke stap, maar voor iedereen die betrokken is bij zorg en welzijn, de patiënt voorop.

Vanuit dit perspectief was er een hernieuwde kennismaking met Harry Crebolder, die ik weliswaar kende, maar waarmee ik niet eerder een zo langdurige en intense samenwerking heb gekend als in de vocrbije twee jaar. Harry is zo'n idealist, zoals ik in een eerdere passage omschreef. Ondanks het feit dat hij zijn sporen reeds ruimschoots had verdiend en ook had kunnen kiezen voor een slotakkoord binnen de veilige grenzen van de door hem geleide capaciteitsgroep Huisartsgeneeskunde zijn wij samen aan de slag gegaan om invulling te geven aan de structuur van BZe VIl: de Transmurale Zorg.

Niet alleen heeft dit geleid tot het oprichten van een afdeling Huisartsgeneeskunde als medisch afdeling van het ziekenhuis, maar ook tot een inhoudelijk debat over de positie van onderzoek in het kader van zorgvernieuwing en de wijze waarop de toekomst van de huisartsgeneeskunde kon worden veillig gesteld in het krachtenveld, waarvan ik u de contouren bij de aanhef van dit verhaal heb 
geschilderd. Zo kon het niet anders of we liepen al heel gauw op tegen wat een confrontatie leek tussen de oude en de nieuwe wereldorde: de schijnbare onverenigbaarheid van het principe van de huisarts als centrale zorgverlener en de uitgangspunten van diseasemanagement. In die laatste situatie dreigde de huisarts inderdaad een marginale rol over te houden, weggedrukt in een systeem waarin de specialist, ondersteund door enthousiaste verpleegkundigen de zorg voor chronische patiënten volledig overnam, overigens met veronachtzaming van het feit dat veel patiënten tussentijds zowel voor de "disease" als al het andere dat hun welzijn betrof toch aangewezen bleven op diezelfde huisarts. Het is een heel debat geworden, waaraan alle partijen inhoudelijk een belangrijke bijdrage hebben geleverd. Harry was de motor om het debat gaande te houden en het te verheffen van een gewoon verschil van inzicht tot een fundamentele discussie over normen, waarden en uitgangspunten. Uiteindelijk zijn we daar goed uitgekomen: het Quattromodel werd geboren. (1)

Natuurlijk is dit niet het alpha en omega van de positie van de huisartsgeneeskunde, maar het heeft er wel aan bijgedragen dat de centrale positie van de huisarts in de organisatie van de gezondheidszorg kon worden gehandhaafd of zelfs versterkt, zonder dat nieuwe, voor de patiënt mogelijk profijtelijke inzichten, zoals die van disease- management hierdoor werden geblokkeerd.

Persoonlijk denk ik dat in de uitvoeringspraktijk van zowel disease management als het quattromodel noğ steeds onvoldoende gebruik wordt gemaakt van de mogelijkheden die er zijn voor substitutie van medisch door verpleegkundig handelen. Meer nog dan nu het geval is kunnen huisarts en specialist zich richten op de rol van regisseur: zij stellen de diagnose, kiezen voor het zorgprogramma, bewaken het proces en zijn verantwoordelijk voor de noodzakelijke individualisering, maar de verpleegkundige en andere ondersteuners zullen uitvoerend zijn en zo de span of control van de arts doen toenemen: de genoemde modellen laten daarvoor de ruimte en zijn zo niet alleen instrumenteel in de zorg, maar ook op het niveau van beleid dat, zo het zich nu laat aanzien, nog lange tijd gedomineerd zal worden door een zorgvraag die het zorgaanbod overtreft. 
Veel subtieler dan inspector Callaghan, een creatie van Clint Eastwood, waarvoor ik, ik beken het met enige gene, thuisblijf, maar met een zelfde doortastendheid en gedrevenheid, zoals geillustreerd met een voorbeeld uit velen, heeft Harry Crebolder de vaak volle agenda van mij en velen in de zorg ten goede bijgesteld:

he made my day!

\section{Literatuur}

1. George Beusmans, Harry Crebolder, Jan van Ree: Zorg voor chronisch zieken. Medisch Contact ; 56(7): 259-262

Dr. Hans Fiolet is directeur Transmurale Zorg, BZe VII, azM. 


\section{Het Gezondheidscentrum Withuis, werkplaats voor nieuwe ontwikkelingen}

\section{Harry Crebolder, mede-kartrekker en initiator}

Tonnie van Kessel, namens het Withuis.

In 1972 werd de net uit Afrika teruggekeerde Harry Crebolder gevraagd te solliciteren in Venlo. Een groep van drie huisartsen (Remy van der Grinten, Fons Receveur en Han Smits) willde een gezondheidscentrum oprichten.

In de enerverende jaren die daarop volgden kreeg het gezondheidscentrum Withuis gestalte.

Huisartsen, assistentes, wijkverpleegkundigen en maatschappelijk werkenden gingen een samenwerkingsverband aan. Pas veel later kwam de thuiszorg erbij.

De huisartsen en assistentes gingen in loondienst bij de Stichting Het Withuis, de andere disciplines werden gedetacheerd.

Deze organisatievorm is van groot belang gebleken. Met name om de werkers onafhankelijk van financiële belangen te kunnen laten functioneren. Het ging ook landelijk gezien om een hele nieuwe ontwikkeling.

Van meet af aan bleek Harry een enthousiaste pleitbezorger van het gezondheidscentrum.

Hij besloot al vrij snel om een onderzoek te doen naar de effecten van het samenwerken op de patiëntenzorg. In $1975 \mathrm{kreeg}$ dit gestalte in de promotie: Onderzoekingen rond een gezondheidscentrum. Cliënten, cijfers, beschouwingen. Promotor: prof. dr. F.J.A. Huygen.

De eerste periode kenmerkte zich door hektiek, maar ook door enorm engagement van de medewerkers en patiënten. De organisatie was democratisch opgezet. ledereen besliste mee over bijna alles. De artsen waren zeer nauw betrokken bij de organisatie en het management.

Evenals zijn collega toonde Harry een enorme inzet.

Veel tijd moest besteed worden aan de financiële onderbouwing. Men wille echter meer dan een goede organisatie.

Met name verder inhoudelijk opbouwen van het multidisciplinaire samenwerkingsverband en gebruik makem van een zo grote 
patiëntenpopulatie (van ong.10.000) voor onderzoekdoeleinden. Vooral het laatste heeft de aandacht van Harry gekregen.

Hij profileerde zich als wetenschapper en groot voorstander van wetenschappelijk onderzoek in de huisartsenpraktijk.

Daarnaast werd vanuit het Withuis regionaal de toon gezet in de positionering van de huisartsgeneeskunde. Dit leidde tot discussies tussen de 1 en ze lijn, die soms uitmondden in een regelrechte strijd om verwijskaarten.

Onderwerpen die eind jaren zeventig en begin jaren tachtig de aandacht hadden in het Withuis waren de jeugdgezondheidszorg en diabetes. Het behoud van de jeugdgezondheidszorg voor de re lijn is een belangrijk strijdpunt geweest.

Harry is de kartrekker geweest bij het opzetten van een speciaal diabetes spreekuur en heeft hierover ook gepubliceerd.

In 1981 is Harry parttime gaan werken als huisarts (50\% huisarts, 50\% in het ALCO project in Nijmegen), de eerste schreden op weg naar het hoogleraarschap werden zo gezet. In de vorm van een duopraktijk werkte hij samen met Tonnie van Kessel, de eerste vrouwelijke collega in het Withuis. Het Withuis was hiermee de eerste huisartsenpraktijk in Venlo waar parttime gewerkt werd. Binnen de hagro Venlo leidde dit tot felle discussies over continuitteit van huisartsenzorg.

In het midden van de tachtiger jaren is de discussie op gang gekomen over academisering van het gezondheidscentrum. Die is onlosmakelijk verbonden geweest met de carrière van Harry Crebolder. De academisering paste helemaal in zijn visie op de eerste lijnsgezondheidszorg.

Binnen het Withuis is daarover lang nagedacht, met een intensieve weging van voor-en nadelen.

Uiteindelijk is besloten om akkoord te gaan. De academisering bracht weer veel nieuwe ontwikkelingen mee zoals verbouwing, meer personeel, meer parttimers in huis, meer studenten en onderzoekers en... de automatisering. Het geacademiseerde centrum werd opgenomen in het RNH registratienetwerk. 
Inmiddels is de academisering een onlosmakelijk deel geworden van het gezondheidscentrum.

Het academiseringsproces heeft vervolgens weer bijgedragen tot nieuwe ontwikkelingen. Het oefende onder andere aantrekkingskracht uit op nieuwe collegae, die daarvoor naar het Withuis en naar Venlo kwamen, uit andere delen van Nederland. Zij hebben de academisering verder mee vorm gegeven.

De afgelopen jaren heeft het gezondheidscentrum zich bezig gehouden met zorgvernieuwingsprojecten en met het verbeteren van de managementstructuur.

Enkele collegae zijn gepromoveerd of gaan promoveren.

Ook bij deze situaties is Harry Crebolder betrokken, al is het niet meer als kartrekker. Echter wel met zijn visie en ervaring.

Het gezondheidscentrum zou als voorbeeld kunnen dienen voor toekomstige samenwerkingsverbanden van huisartspraktijken en HOED constructies. De ervaring van bijna zo jaar werken in teamverband en experimenteren met allerlei inhoudelijke en managementconstructies zou anderen van pas kunnen komen. Misschien dat Harry na zijn pensionering ook hieraan nog een bijdrage wil leveren??

Mevr. A. van Kessel is huisarts in het Gezondheidscentrum Withuis te Venlo. 


\section{Huisarts Harry Crebolder: een persoonlijkheid}

Thema: "De huisarts als medicijn" of wel: de rol van de persoon van de huisarts in het huisartsgeneeskundig handelen.

Tonnie van Kessel.

Dit jaar is het 30 jaar geleden dat Harry Crebolder in Venlo in de huisartsenpraktijken van Remy van der Grinten, Fons Receveur en Han Smits als huisarts ging werken. Een jaar later zouden deze overgaan in het gezondheidscentrum withuis.

Harry is in 1981 als huisarts parttime gaan werken en stopte in 1995 helemaal met zijn huisartsen werk (gedurende de laatste jaren nam het aantal spreekuren geleidelijk af naar uiteindelijk nog een halve dag).

Ter afsluiting van zijn werkend leven wilde Harry nog eenmaal terugkeren in de praktijk. Het merendeel van zijn patiënten van toen is nog steeds in het Withuis Met name in de praktijken van Tonnie van Kessel en Henk van Dam. Harry is twee dagen onze gast. Hij woont spreekuren bij en rijdt visites, gaat mee op ziekenhuisbezoek en neemt deel aan teambesprekingen.

Het is een feest van herkenning en weerzien.

In de weken voorafgaande aan het bezoek heb ik bij een aantal patiënten aangekondigd dat hij op de bepaalde datum zou komen. Op het spreekuur kwamen nu ook mensen zonder klachten. Zij kwamen speciaal voor "dokter Crebolder".

Maar ook degenen die onverwacht geconfronteerd werden met zijn aanwezigheid waren aangenaam verrast. Oude verhalen werden opgedist, anekdotes verteld.

Harry is en was een zeer geëngageerd huisarts.

In de periode dat ik in het Withuis kwam werken (1981) had hij een bijzondere uitstraling. Vaak werd gemeld hoezeer dokter Crebolder betrokken was geweest bij belangrijke zaken in het leven van de mensen: geboorte, dood, ernstig ziektes, moeilijke keuzes. Buiten diensten om werd er thuis gebeld en ook op feesten en bij bijzondere gebeurtenissen was hij van de partij (recepties etc). Hij gaf de patiënten het gevoel: ik sta voor je op de bres, je bent 
belangrijk, ik doe moeite voor je. Maar ook: dit is mijn mening, zo is het, zo moeten we het gaan doen, en "dit kunnen we ook best zelf", je hoeft niet voor alles naar het ziekenhuis. Dit leverde de huisartsen van het Withuis op een gegeven moment de naam op: "de doe het zelf dokters".

Harry's vaderlijke en zorgende houding heeft bij veel patiënten een gevoell van veiligheid opgeroepen, en veell vertrouwen

Om bovenstaande nog duidelijker te maken enige casus:

\section{"Hare Majesteit"}

Mevrouw $M$, inmiddels 91 jaar, woont al jaren in een verzorgingshuis. Harry heeft een onuitwisbare indruk op haar gemaakt omdat hij direct aanwezig was, toen haar man een hartinfarct kreeg, inmiddels ongeveer 25 jaar geleden. Sindsdien kan hij geen kwaad meer bij haar doen. Bij ieder bezoek wordt hij stevig omhelsd en het zeepje voor de dokter ligt nog altijd klaar (als een soort relikwie), maar mag niet door zijn opvolger gebruikt worden. Wel wordt de opvolger ook regelmatig omhelsd, wat als een erfenis van zijn voorganger, als ritueel is blijven bestaan.

\section{Wies}

Wies, 57 jaar, komt op het spreekuur.

Ze heeft geen klacht. Wel heeft ze een foto, bij van haar gezin:

4 kinderen, 10 kleinkinderen, prachtige mensen allemaal. Trots vertelt: ze over hoe goed het ze gaat. En met haarzelf?? Mies heeft een zwaar leven achter zich, met veel ziekte, veel somatische als ook psychosomatische ziektebeelden. De grootste crisis in haar leven is veroorzaakt door de dood van haiar man, nu 8 jaar geleden, hij was toen 48 jaar. Het rouwproces was hevig en langdurig. Ze moest zelfs een periode opgenomen worden op de paaz. En ... "wie geit ut?"; "dokter... "t geit".

Harry wordt bijgepraat over de afgelopen jaren. Dertig jaar gezinsgeneeskunde ontvouwt zich.

in de loop der jaren informeerde Wies vaak naar dokter Crebolder, naar zijn werk in Maastricht en naar zijn gezondheid en familie. 


\section{Familie $M$}

De famille M. (Vader L. 75 jaar, Moeder W. 73 jaar, Dochter A. 38 jaar) woont afgelegen in een oud groot tuindershuis. Jarenlang, bij bijna ieder huisbezoek van mij was een van de vragen: ziet $U \mathrm{dr}$. Crebolder nog wel eens..., hoe gaat het met hem? En hoe gaat het met Emmy? is hij nog steeds professor in Maastricht? Etc.. Bij aankomst voor de middagvisite staat de koffie klaar, en gebakjes. Een gesprek over de gebeurtenissen van de afgelopen jaren volgt. Over ziekte en ziekenhuisopnames, over de kinderen en A., hun inwonende dochter die psychiatrisch ziek is. De zorgen over haar isolement. Dochter A laat zich niet zien.

Mevrouw komt met een foto van jaren geleden, de receptie van hun 25 jarig huwelijk, waar dokter Crebolder aanwezig was en zich liet fotograferen met haar.

Vroeger, als hij kwam, dan at hij soms mee. Of hij kreeg aardbeien en groente mee. Het persoonlijk engagement van Harry met deze mensen was groot.

De geschiedenis van deze familie is bijzonder, de rol van de huisarts cruciaal. De persoon van de huisarts is voor hen van groot belang, men hecht zeer veel waarde aan de persoonlijke band met de dokter.

\section{Mevrouw A.}

Mevrouw is 79 jaar, gehuwd. Ze heeft een lange medische voorgeschiedenis. Bij het zien van Harry Crebolder zei ze: "Weet $u$ nog dokter, dat u met de vuist op tafel sloeg? Ik moest mij van $u$ laten opereren, wat ik zelf niet van plan was. $U$ was erg boos. $U$ had het goed gezien, want de operatie was hard nodig".

Behalve een huisarts met deze persoonlijke kenmerken was Harry ook een deskundig arts met veel vaardigheden en een eigen visie. De persoon van de dokter gekoppeld aan visie en deskundigheid, een mool beeld van de huisartsgeneeskunde, door Harry Crebolder beoefend en uitgedragen.

Mevr. A. van Kessel is huisarts in het Gezondheidscentrum Withuis te Venlo. 


\section{Afscheid van Harry}

Annie Hendriks.

Harry neem dit jaar afscheid van de universiteit en hopelijk kan ik er dit jaar wél bij aanwezig zijn. Bij zijn afscheid in het GC "het Withuis" was het feest me aan mijn neus voorbij gegaan helaas. Ik woonde in die tijd te dicht bij de Maas met als gevolg dat door de hoogstand van het water ik mijn dorp niet kon verlaten. Alle wegen waren geblokkeerd en je huis verlaten op zo'n moment doe je ook niet.

Ik heb niet zo lang met Harry samengewerkt. Vanaf december 1992 tot aan zijn afscheid. Hij kwam dan op woensdagmiddag vanuit Maastricht met de trein naar Venlo spreekuur doen en altijd was het weer bekijken wie Harry van het station kon afhalen. Meestal kwamen we daar wel uit.

Hij deed in die middag met veel enthousiasme spreekuur. Wat me altijd aan hem opviel was dat hij heel veel tijd en aandacht besteedde aan zijn patiënten. Hij had iets vaderlijks over zich wat heel betrouwbaar overkwam. Volgens mij zag Harry dit ook als een uitdaging. De patiënt kwam dan ook op de allereerste plaats. De patiënten droegen hem op handen, maar ook jaren na zijn afscheid bleef hij erg geliefd.

Als medewerker van het GC was dit gegeven niet altijd makkelijk. Het betekende vaak je eigen schema omgooien wat je voor die middag gepland had want als er lemand een behandeling in de behandelkamer nodig had, mocht deze vooral niet al te lang wachten.

Daarentegen had hij heel veel interesse in ieder mens. Had aandacht voor je "wist b.v. ook altijd waar je op vakantie was geweest en vroeg er dan ook naar. De persoonlijke benadering ondanks dat ik hem maar een halve dag in de week zag, heb ik altijd alls zeer prettig ervaren.

Het is nu drie jaar geleden dat ik hem weer tegenkom op de werkvloer en wel op de universiteit. Vaak zie ik hem niet, ik ben zelf veel op pad, maar toch is er nog altijd een gevoel van herkenning. ooit hebben we samengewerkt in dat Gezondheidscentrum in Venlo. 
Mevr. A. Hendriks werkte als doktersassistente in het GC "het Withuis" en is nu werkzaam als researchassistente bij de Capaciteitsgroep Huisartsgeneeskunde van de UM. 


\section{E en professor neemt afscheid, en neemt de huisarts met zich mee.}

San van Rooij.

Prof. dr. H.F.J.M. Crebolder neemt afscheid. De professor; Harry voor intimi, en overigens ook voor alle anderen, heeft na 15 jaren inzet voor onderwijs, onderzoek en zorg besloten dat het goed geweest is en gaat genieten van zijn welverdiende postacademische periode. Een afscheid dat niet ongemerkt voorbij mag gaan en vandaar dat een aantal "keymen" gevraagd is een bijdrage te leveren voor een 'liber amicorum".

Ook ondergetekende, vertegenwoordiger van de leveranciers van de zorg, is gevraagd een bijdrage te leveren.

Voorwaar een eervolle maar beslist geen eenvoudige opgave. Hoe kan een huisarts die niets anders gewend is dan alle grote en kleine (levens)vragen in 10 minuten op te lossen en in 4 zinnen samen te vatten, enkele A4-tjes vullen zonder te lopen over platgetreden paden dan wel te vervallen in obligate hoffelijkheden. Anderzijds, Harry verdient dat er ook gesproken wordt over zorg en met name over de zorg betreffende de zorg, door de zorg. Want jij, Harry, hebt er voor gezorgd dat "zorg" weer hoog op de agenda kwam te staan binnen de capaciteitsgroep Huisartsgeneeskunde en daar zijn wij, zowel nietacademische als academische huisartsen je zeer dankbaar voor.

Subjectief gezien viel het 15 jaar geleden allemaal reuze mee. Persoonlijke, continue en integrale zorg was een vanzelfsprekendheid, evenals het vak als roeping. Er werd niet gesproken over lange werkdagen, niet gesproken over lange wachttijden in de zorg en niet gesproken over lange gezichten bij collega's of hun echtgenotes. Hooguit werd gesproken over de lange wachttijd voor de opleiding, het lange wachten op een eigen praktijk of over de langverwachte standaarden.

Het vak was in beweging. Vele onderwijsprogramma's werden ontwikkeld en even zovele onderzoeksprojecten werden opgestart. Onderwijs en onderzoek dienden zich aan als belangrijke pijlers waarop het vak 'huisarts' verder uitgebouwd zou kunnen worden. Naast de zorg waren dit twee belangrijke hoeksstenen waarmee de fundamenten van de huisartsgeneeskunde verder versterkt zouden kunnen worden. 
De opleiding tot huisarts had zich in zijn jonge bestaan bewezen, en zou verder worden uitgebreid. Het opleiden van huisartsen was een eer, vroeg om bovenmodale kwalliteiten en was dus niet voor iedereen weggelegd. In het basiscurriculum werd de binding met de huisartspraktijk verder geintensiveerd; het scholen van jonge dokters behoorde tot een gezamenlijke verantwoordelijkheid voor de gehele beroepsgroep. Evidence-based medicine deed zijn intrede. Vele promovendi in spe wijzen ons op onze onmisbare inzet in deze. Harde cijfers zijn nodig. Alleen dan kan de empathische, holistisch werkende huisarts een extra dimensie toevoegen aan zijn functioneren. Het vak in beweging, niet minder dan welk klinisch specialisme dan ook, een vak voor de toekomst. De huisarts als spil van de gezondheidszorg.

Objectief de ontwikkelingen in ogenschouw nemende, is er afgelopen 15 jaren een totaal ander omgevingsveld ontstaan waarbinnen de huisartsgeneeskunde zich staande moet zien te houden.

Dubbele vergrijzing en ongelimiteerde zorgvraag, welke mede gezien moet worden in het licht van het wegvallen van sociale netwerken en een medicalisering van de samenleving waar het medisch circuit mede gebruikt wordt voor validering van disfunctioneren en het garant stellen van inkomen, heeft gezorgd voor een schier onbeheersbare druk op de voordeur van de huisarts.

Tweeverdieners hebben nu eenmaal weinig tijd voor ouders en andere familieleden, warbij in gezinnen met een of twee kinderen toch al weinig gedeeld kan worden als de mantelzorg wordt ingeroepen.Ook blijft er weinig tijd voor hobby of verenigingsleven, waardoor vele hulplijnen wegvallen welke voorheen wel ingeroepen konden worden. Sociale en emotionele verarming in de samenleving. En als er dan ook nog kinderen komen blijkt al snel dat het zeer moeilijk is om alle rollen naar behoren te vervullen, waarop uitval - en werk is de eerste en makkelijkste prooi - slechts een kwestie van tijd is. Om inkomen en hypotheek dan veilig te kunnen stellen is een medische diagnose noodzakelijk, waarmee de conceptie van Whiplash, fibromyalgie, RSI, ME en aanverwante diagnoses een feit werd. Daarnaast werd de achterdeur bij de huisarts op een kier gezet. Zlekenhuizen transformeren van "huis voor zieken" naar klinieken 
waar alleen nog ruimte is voor diagnostiek en het initiëren van behandeling. Verdere behandeling en de zorg voor chronisch zieken werd "getransmuraliseerd", waardoor er ruimte kwam in de kliniek voor verdere reductie van ligdagen en het uitbreiden van academische taken. Personeelstekorten deden wachtlijsten verder oplopen.

Verpleegklinieken kampten met beperkte capaciteit en zorginstellingen hadden, al dan niet door het tijdsbeeld bepaald, veel oog voor tijdschrijven een marktwerking. Een marktwerking welke ook door ziektekostenverzekeraars werd omhelsd en zich misschien wat kort door de bocht al snel vertaalde in communicatie naar de verzekerde dat alles kan en communicatie naar de dokter dat niets mag. De introductie van een 24-uurs maatschappij verhoogde de druk op de persoonlijke continue zorg; een zorg welke extra onder druk komt te staan door de meer dan volledige emancipatie van opleiding geneeskunde en huisartsgeneeskunde waardoor er weldra een serieus capaciteitsprobleem zal ontstaan. Daarnaast zien we de afgellopen jaren een juridisering binnen de gezondheidszorg, welke defensieve geneeskunde uitlokt en profileerden zich tuchtcollege's als belangrijke bewakers van de kwaliteit van de zorg. Ziedaar een maatschappij in beweging, ziedaar de huisarts, de spil in de gezondheidszorg.

Evaluatie binnen de beroepsgroep van eerder genoemde ontwikkelingen leidde de afgelopen jaren tot onrust. Er zat een te groot verschil in de manier waarop wij vonden dat het vak uitgeoefend zou moeten worden en de praktijk van alle dag. Deze onrust werd door velen geaccepteerd, als begrijpelijk ervaren maar heeft wellicht te vaak vertaalt in pecunia geen positieve bijdrage geleverd aan het imago van de huisartsgeneeskunde en dat van de individuelle huisarts.

De huisarts voelde zich ziek, besmette daardoor ook de huisartsgeneeskunde.

Dit leidde tot zorg, zorg welke de capaciteitsgroep huisartsgeneeskunde vertaalde in zorg voor de huisarts en zorg voor de zorg die deze huisarts wenste te leveren.

Harry, want zo noemen intimi hem, had een: 


\section{Plan}

Het moest gedaan zijn met het negatieve zelfbeeld. Bedreigingen werden omgevormd tot kansen.

Zorg moest weer het centrale thema zijn voor de huisarts en de vakgroep huisartsgeneeskunde.

Geen schisma tussen academische en niet-academische huisartsen, samen sterk!

Ketenzorg werd de rode draad. Partners in de zorg, samen aan tafel. De introductie van nieuwe zorgmodellen om patiëntengroepen te bedienen, gezamenlijke triage om patiëntengroepen te sturen, gezamenlijke strategieën bedenken om voor-en achterdeur problematiek beheersbaar te houden. De vakgroep als ondersteuner voor de huisarts.

Dit gekoppeld aan facilitering welke door anderen voor hun rekening genomen zou worden en ziedaar, een krachtig geheel waarmee de huisarts en de huisartsgeneeskunde de komende jaren verder kunnen. Dit alles verpakt in een afdeling van het academisch ziekenhuis waar het hoofd van de vakgroep tevens het hoofd is van deze afdeling en ziedaar, de verankering van de huisarts is een feit.

Een stabiele constructie waarmee de verdere ontwikkeling van het vak huisartsgeneeskunde gewaarborgd werd.

Met de omvorming van het Transmuraal Diagnostisch Centrum naar Bze-VIl en de positionering van de vakgroep daarin, heeft Harry ervoor gezorgd dat de zorg weer centraal staat.

Organisatie en uitvoering van zorg welke als primair proces de meeste aandacht dient te krijgen, ook in academische setting.

Professor Dr. H.F.J.M. (u weet wel, Harry) Crebolder neemt afscheid.

Hij neemt de huisarts met zich mee, maar zorgde voor een infrastructuur waarin een nieuwe huisarts zich kan vormen.

Een nieuwe huisarts als spil in de gezondheidszorg.

J.R.A.Y. van Rooij, huisarts te Maastricht, is voorzitter van de Regionale Huisartsenvereniging Heuvelland. 


\section{Help, de huisdokter verzuipt!}

Jos van Engelshoven.

Vroeger was een huisarts een dokter die je thuis bezocht als je ziek was. Het woord "huisarts" zegt het al. De dokter kwam bij de patiënt thuis of de patient kwam bij de dokter thuis. Als student geneeskunde, in de jaren zestig, leerde ik dat in de eerste situatie consult bij de patiënt thuis - de huisarts sterk in het voordeel was ten opzichte van de specialist vanwege de mogelijkheid de patiënt in zijn thuissituatie te kunnen observeren. Dat zou helpen bij het stellen van een diagnose. Bovendien kon beter beoordeeld worden of, rekening houdend met de thuisomstandigheden, eventuele therapeutische adviezen opgevolgd zouden worden. De tweede situatie - consult bij de huisarts thuis - bood soms ook aanzienlijk voordeel omdat daar de benodigde diagnostische en therapeutische hulpmiddelen beschikbaar waren en de communicatielijnen kort bleven. Zowel de huisarts als zijn assistente kenden de patiënt en zijn familie goed en konden door de telefoon de urgentie van het probleem beoordelen en het tijdstip van de afspraak daarop afstemmen. De privacy was vanwege de thuissituatie maximaal en de hoeveelheid administratie minimaal. De huisarts bood in die tijd integrale zorg: hij onderkende ziekte en gezondheid, hij deed aan gezinsbegeleiding, hij was paraat voor de bevalling en hij bemiddelde bij de gang naar zieken-, bejaarden- of verpleeghuis. Zijn bijscholing bestond uit het bezoeken van de refereeravonden in het plaatselijke ziekenhuis, een discussie met de artsenbezoeker en het lezen van het Nederlands Tijdschrift voor Geneeskunde. Van standaarden, protocollen en richtlijnen had hij nog nooit gehoord en zijn geneeskunde was "experience based" en niet "evidence based" en die experience was uiterst persoonlijk getint.

Het ziekenhuis was toen nog "een huis voor zieken". Daar werd je naar verwezen als er echt problemen dreigden. De patiënt werd dan vaak "ter observatie" opgenomen en de specialist liep dagelijks met de hoofdzuster "visite". Zo'n opname kon weken duren tot de tijd leerde wat er aan de hand was. Of niet. Buikoperaties waren veelal "proeflaparotomieën ", of in modern jargon "kijkoperaties", bedoeld om het eventuele onheil sneller aan het licht te brengen. Een zekere 
diagnose vooraf was er zelden. De hoeveelheid beschikbare technologie was nog beperkt en van magnetische resonantie tomografie, echografie of gastroscopie had men nog nooit gehoord. Het aantal specialisten was nog beperkt evenals het aantal specialistische maatschappen. Wel waren er veel zorgzame verpleegsters en een patiënt kon zonodig altijd opgenomen worden. Desnoods werd er in de badkamer een bed bijgeplaatst. Een ex-hulsarts, die het wat rustiger aan wilde doen, speelde directeur-geneesheer en om er bij te horen en gezag uit te stralen kleedde hij zich meestal in het wit. Veel had hij echter niet te vertellen. Er waren weinig mannen in grijze pakken, de witten hadden verre de overhand, en er werd weinig vergaderd.

Anno 2002 is het ziekenhuis echter geen huis meer voor zieken maar een "diagnostiek en behandelcentrum", een technologische instelling waar voor echte zieken geen plaats meer is. Die moeten naar een verpleegtehuis, een herstelcentrum, een sterfhuis of gewoon naar huis. Het aantal patiënten dat in het ziekenhuis overlijdt is fors gedaald omdat ze vóór overlijden worden ontslagen. Niet omdat de behandeling beter is. Het ziekenhuis is een "efficiënt" gerund bedrijf met veel mannen en vrouwen in grijze pakken, altijd bezette vergaderkamers en steeds minder wit. Het is een technocentrum met voor een vermogen aan apparatuur en honderden medisch specialisten die elk alles weten van een relatief klein deel van de geneeskunde en die over alle benodigde vaardigheden beschikken om de patiënt beter te maken onder voorwaarde dat die patiënt de ziekte heeft waarin ze gespecialiseerd zijn. Zo niet dan wordt een ander medisch specialist in consult geroepen en als die het ook niet weet komt een derde, enzovoorts. Het is ook geen huis waar je als patiënt zo maar terecht kornt. Dat duurt soms maanden en als je eenmaal binnen bent probeert men je weer zo snel mogelijk te lozen.

Niet alleen het ziekenhuis, ook de huisarts is veranderd. Huisartsen anno 2002 werken vaak in groepsverband en de praktijk aan huis heeft plaats gemaakt voor een gezondheidscentrum. Visite rijden is er vrijwel niet meer bij. Van 12 tot 14 uur is de dokter lunchen en om 17 
uur gaat de telefoonbeantwoorder aan. Na een nachtdienst in de huisartspost van het ziekenhuis komt een vervanger omdat de dokter anders het benodigd aantal uren rust niet haalt. De huisarts van nu wordt geassisteerd door een COPD-verpleegkundige, een hartfalen-

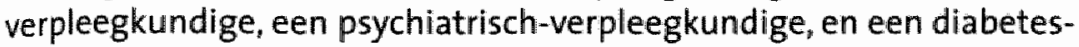
verpleegkundige. De kinderen worden als vanouds gezien door de consultatiebureau-arts, de bevalling wordt gedaan door de vroedvrouw, voorlichting over geneesmiddelen geeft de apotheker, de wijkverpleegkundige zorgt voor de zieke en zorgbehoeftige thuis en het RIO "indiceert" de patiënt voor het verpleegtehuis. Kortom de huisarts is geen huisarts meer. Hij komt nog maar sporadisch bij de patiënt thuis, hij is slechts een deel van de dag beschikbaar voor zijn patiënten en hij levert geen integrale zorg meer. Huisarts zijn is nu gewoon een "baan". Daar gaat hij "s morgens naar toe, zijn werktijden zijn geregelld en hij werkt niet meer solistisch maar samen met anderen en hij besteedt eindeloos veel tijd aan overleg en verantwoording. Hij moet zich jaarlijks nascholen, werken volgens standaarden en richtlijnen van het Nederlands Huisartsen Genootschap en hij moet zijn aanvraag- en voorschrijfgedrag verdedigen ten overstaan van collega's, paramedici en zorgverzekeraar. Allemaal prima, maar 't kost wel tijd en er blijft steeds minder tijd over voor de patiënt. Bovendien is de vertrouwelijkheid vaak zoek, omdat velen over zijn schouder meekijken. Dat dit laatste niet altijd zonder gevaar is getuige de schandalige handelwijze van een verzekeringsmaatschappij die huisartsen een bonus toezegt, indien zij minder geneesmiddelen voorschrijven. Dit is vergelijkbaar met het toekennen van een premie aan een arts op een intensive care indien de patiënt eerder overlijdt. Ook dat bespaart geld.

De patiënt anno 2002 is veeleisend. Alles moet en het moet vooral ook snel. Een afwachtend beleid is er niet meer bij. De patiënt wil snel zekerheid en garanties. Hij eist een scan, behandeling of verwijzing en voor zaterdag weer beter. Soms is hij door internet al geïformeerd over mogelijkheden en kansen en komt op het spreekuur met het verzoek "of de dokter die paar moeilijke woorden nog kan uitleggen". 
De huisarts wordt door patiënt en maatschappij gebruikt om dingen te regelen want de dokter is nog altijd de legitimatie voor ziek zijn en weer gaan werken en voor een uitkering of een voorziening. $\mathrm{Hij}$ bevindt zich daardoor soms in een spagaat tussen patiënt, maatschappij en geweten. En bij dat alles komt nog dat zijn inkomen aan erosie onderhevig is. Nee, van het klassieke vrije beroep met aanzien, waardering en een goed inkomen is weinig over en het is dan ook niet verwonderlijk dat huisartsopleidingen geen leerlingen kunnen krijgen.

Terwijl de huisdakter steeds meer onder druk is komen te staan heeft de huisartsgeneeskunde als wetenschappelijk discipline zich sedert de jaren zestig enorm ontwikkeld en een academisch profiel gekregen. Er is een wetenschappelijke fundering gelegd onder het vakgebied. Er zijn hoogleraren huisartsgeneeskunde en huisartsinstituten met geacademiseerde praktijken. Aanstaande collegae die zich willen vestigen maeten eerst een drie jarige beroepsopleiding huisartsgeneeskunde volgen om vaardigheden en technieken te leren die ontbreken in de opleiding voor basisarts, maar die wel noodzakelijk zijn voor een adequate beroepsuitoefening.

Er zijn gepromoveerde huisartsen die protocollair en "evidence based" werken volgens de beschikbare standaarden. Kortom de huisartsgeneeskunde is volwassen geworden.

Toch betwijfel ik of de huisarts zal overleven. De bovenbeschreven trend zal immers verder doorzetten en de huisdokter oude stijl, de dokter die zonder zijn computer te raadplegen op de hoogte is van de ziektegeschiedenis en gezinssituatie van de patiënt, de dokter die de patiënt thuis opzoekt en die integrale zorg levert, zal mijns inziens geheel verdwijnen. De huisdokter zal zich noodgedwongen steeds verder gaan organiseren om niet te verzuipen in de wirwar van zorgaanbieders, regelaars in grijze pakken, technologieën, ziekenhuiskastelen en verzekeraars. Wat begonnen is als de huisdokter op de hoek en uitgegroeid is naar een groepspraktijk van drie of vier huisartsen in de wijk zal verder doorgroeien naar een "medische centrum" dat verantwoordelijk is voor de algemeen 
geneeskundige zorg voor een geheel dorp of stadsdeel en dat veel artsen ("general practitioners" = GP's), verpleegkundigen en andere paramedici in dienst heeft. Een centrum dat van voldoende omvang is om op basis van gelijkwaardigheid te onderhandelen met andere zorgaanbieders en verzekeraars en dat gemanaged wordt door mannen en vrouwen in grijze pakken. Een medisch centrum dat uiteindelijk, om te overleven, strategische allianties of fusies aangaat met verpleegtehuizen en ziekenhuizen en daar uiteindelijk weer in opgaat omdat "groter en efficiënter" door vrouwen en mannen in grijze pakken meestal vertaald wordt als "beter". Vrouwen en mannen in witte pakken weten dat dit lang niet altijd zo is.

Prof. dr. J. van Engelshoven is hoogleraar radiodiagnostiek en voorzitter Stafconvent azM. 


\section{P rof. dr. H.F.J.M. Crebolder: Acht jaar lid van het STOOM-bestuur}

Joop van Londen.

\section{Inleiding}

Van die acht jaar dat Harry Crebolder bestuurder was, heb ik er maar twee mogen meemaken.

Mijn voorganger als voorzitter STOOM-bestuur was mevrouw $\mathrm{mr}$. E. Veder-Smit, voormalig staatssecretaris van Volksgezondheid. Zij zou dus met grater recht een bijdrage aan dit liber amicorum hebben kunnen leveren. Gelukkig voor mij, is mevrouw José Bastiaenen, algemeen secretaris STOOM, zo vriendelijk geweest allerlei gegevens uit het verleden op te sporen, waarvoor ik haar zeer veel dank zeg.

$\mathrm{Nu}$ is de naam STOOM al een aantal malen gevallen zonder dat ik heb uitgelegd wat de letters betekenen. Ik zal dit verzuim nu maar direct goedmaken: STOOM is de Stichting Onderzoek en Ontwikkeling Maatschappelijke Gezondheidszorg.

De stichting beheert een klein fonds, afkomstig uit de nalatenschap van het vroegere kruiswerk.

Met deze gelden worden op basis van door het bestuur gekozen werkplannen steeds voor een periode van een paar jaar, onderzoeksen ontwikkelingsprojecten gefinancierd en daardoor gestimuleerd. Die werkplannen of actieplannen bevatten de prioriteiten zoals het bestuur die ziet, terwijl het advies of commentaar van het veld steeds wordt gevraagd.

Dit is niet altijd zo gegaan. Toen Crebolder in 1994 aantrad, vervulde STOOM nog de rol van subsidiënt en financierde dus projecten die door derden werden aangedragen.

Inhoudelijk lagen de accenten destijds bij zaken als: integratie kruiswerk, gezinsverzorging, de ontwikkeling van het kwaliteitsbeleid van instellingen en substitutie.

Was de activiteit van STOOM destijds meer bottom up, nu moet je het beleid karakteriseren als 'top down'-georiënteerd. 


\section{Thuiszorg}

Thuiszorg is het domein geworden waarop de aandacht van STOOM zich richt.

Het gaat over de patiënt in zijn/haar eigen leefmilieu en het onderzoeken en ontwikkelen van methodes om adequate en kwalitatief verantwoorde zorg aan te bieden uitgaande van de preferenties van die patiënt.

Het gaat vervolgens om de beroepsgroepen die die zorg moeten leveren: hun kennis en (sociale) vaardigheden, hun arbeidsmarkt, hun imago en hun noden en problemen, hun capaciteit.

Thuiszorg is ook het gebied geworden waarop al geexperimenteerd is met marktvormen.

De LVT (Landelijke Vereniging voor Thuiszorg) publiceerde juni 2000 een nota over de toekomst van de thuiszorg: Zorg Thuis, een visie op plaats en betekenis van de thuiszorg in de zie eeuw.

Hierin wordt het veelzijdig behoeftepatroon van mensen in de thuissituatie met functiebeperkingen van al of niet tijdelijke aard geschetst.

De LVT heeft als centrale doelstelling:

"Het zo goed mogelijk tegemoet komen aan de behoefte van mensen aan diensten thüis, voor zover die diensten bijdragen aan het herstel en behoud van de gezondheid en de kwaliteit van het zelfstandig wonen met zoveel mogelijk voortzetting van hun maatschappelijke participatie". (LVT, 2000, blz. 7 uit de samenvatting.)

Er bestaan meerdere omschrijvingen van thuiszorg. Crebolder zelf en ook ik hebben ons daaraan 'bezondigd". Die van de LVT is toch wel de kernachtigste en daarom citeer ik die andere definities maar niet.

\section{Crebolder als relatietherapeut tussen huisarts en thuiszorg}

In de tweede helft van de negentiger jaren ontstonden er allerlei complicaties tussen de beroepsbeoefenaren die de voornaamste rollen spelen in de zorg thuis: de huisarts, de wijkverpleegkundige, de 
gezinsverzorgende, de bejaardenhelpster.

Ook het maatschappelijk werk wordt wel tot de thuiszorg gerekend en sommige auteurs betrekken ook de tandartsen, apothekers en verloskundigen erbij.

De wijkverpleegkundigen beleefden een identiteitscrisis, de huisartsen waren ontevreden over (het gebrek aan) samenwerking met de wijkverpleegkundigen.

In hun strijd om versterking van de huisartsgeneeskunde claimden de huisartsen de introductie van een nieuw beroep: een directe ondersteuning in de praktijk, een ondersteuning die wèl altijd bereikbaar en beschikbaar zou zijn: de praktijkverpleegkundige. Daarvoor kregen die huisartsen ook steun vanuit het nationale volksgezondheidsbeleid, waardoor de wijkverpleegkundigen zich nog meer in de hoek gedreven voelden.

Is de huisarts de vanzelfsprekende schakel in de medische keten, welke rol is er weggelegd voor de wijkverpleegkundige?

Vroeger de natuurlijke partner in het duo arts - wijkverpleegkundige, maar door de komst van de praktijkverpleegkundige werd zij/hij een stapje op afstand gezet.

De wijkverpleegkundige articuleert samen met de gezinsverzorging en het maatschappelijk werk naar het welzijnswerk.

In de loop der jaren heeft de wijkverpleegkundige al vaker van beroepsprofiel moeten veranderen: van cure en care naar preventie en GVO (health promotion) en weer terug.

De revitalisering die is opgetreden, kenmerkt zich daardoor dat de echte verpleegkundige deskundigheid toch weer als de centrale factor van de identiteit wordt beleefd. Vandaaruit ontwikkelen zich ook nieuwe wijkverpleegkundige specialisaties.

De ontwikkeling van transmurale zorg en van de medische- en verpleegkundige technologie dragen daaraan bij.

Ook de community care (volgens oud WHO-recept) wordt nieuw leven ingeblazen terwijl de mogelijkheden van de informatie- en communicatietechnologie nog goeddeels moeten worden verkend.

Al deze ontwikkelingen deden een zwaar appél op de inzet van de 
bestuurders. Maar het enthousiasme was groot, de motivatie hoog en de leiding bezielend. Er werd vaak en laat vergaderd en druk geïnvesteerd in extra taken (voorzitterschap, pleitbezorging, overleg). ook Crebolder toont zich in deze fase een actief en betrokken STOOM-lid en neemt - niet verwonderlijk - een hoofdrol op zich bij het zoeken naar uitwegen uit de impasse in de relatie tussen de huisartsen en de thuiszorg. Hij plaveide de weg voor de samenwerking tussen STOOM en NHG rond de ontwikkeling van samenwerkingsrichtlijnen en beijverde zich voor goede verbindingen tussen het kwaliteitsbeleid van de beide beroepsveiden. Onder zijn leiding kwamen er samenwerkingsrichtlijnen tot stand voor actuele maar ook weerbarstige onderwerpen als decubitus en dementie en werd de basis gelegd voor de officiële erkenning en implementatie daarvan door beide beroepsgroepen.

Voor de thuiszorg is het belangrijk dat huisartsen bij de invulling van de functie van praktijkverpleegkundige niet voorbij gaan aan de mogelijkheden die de wijkverpleging hier te bieden heeft. STOOM en de thuiszorg weten zich ook hier in Crebolder verzekerd van een warm pleitbezorger.

\section{De verhouding vraag naar en aanbod van thuiszorg}

In paragraaf 1 werd al even getipt aan het spanningsveld markt publiek karakter. Dat speelt in de hele zorg een rol.

De Raad voor de Volksgezondheid en Zorg heeft in februari 2002 een advies uitgebracht over de mogelijkheden van commercieel opgezette zorg in een branche die overigens publieke taken uitoefent. Omgeven door veel condities wil de Raad deze zorg toch verkennen. Al in 1987 wijdden Guus Schrijvers en ik in onze inaugurele redes aandacht aan de noodzaak de positie van de vrager / koper te versterken.

Die trend heeft zich sterk doorgezet. Het sterker maken van de positie van de zorg-'consument' is beleidsuitgangspunt geworden en wordt met de term 'empowerment' aangeduid.

De LVT heeft in de nota 'Zorg Thuis' ook positie gekozen. Men schetste de besturingsmodellen voor de collectief gefinancierde thuiszorg. Het eerste sluit het dichtst aan bij het publiek karakter van de thuiszorg 
en het tweede model gaat uit van concurrentie tussen vrij toetredende thuiszorgaanbieders.

De LVT kiest voor het eerste model, ook al op basis van eerdere ervaringen met geprivatiseerde thuiszorg die toch wel erg ten koste ging van de capaciteit van de 'reguliere" thuiszorgorganisaties.

De LVT ziet wel volledige marktwerking weggelegd voor de privaatgefinancierde aanvullende diensten van de thuiszorg. Hier zou dan dus in principe minder overheidsregulering nodig zijn.

Kortom in de arena 'markt en staat' is de thuiszorg al opgetreden en door ervaringen meer geharnast geworden, in beide richtingen.

In deze strijd heeft Crebolder naar mijn weten niet zo duidelijk partij gekozen. Hij wees er wel steeds op dat privatisering gepaard kan gaan met inkomensverhoging, waardoor overheidsdiensten en met name universiteiten in een ongunstige concurrentiepositie geraken op de arbeidsmarkt. Dit zal in zijn ogen gepaard gaan met kwaliteitsverlies bij de "publieke" diensten.

\section{De 'professional Crebolder'}

Crebolder is een professional in hart en nieren. Professionele kwaliteit en effectiviteit zijn voor hem de hefbomen voor zorgvernieuwing en samenwerking en de ultieme garantie voor tevreden patiënten. Inhoudelijke verdieping en wetenschappelijke onderbouwing zijn belangrijke doelen die hij consequent hanteert als maatstaven voor de relevantie van onderzoeks- en ontwikkelingsactiviteiten op het terrein van de zorg.

Hij heeft veel oog en feeling voor het doortrekken van nieuwe lijnen naar de interdiciplinaire toepassingssetting en weet zich als medicus goed in te leven in het professionaliseringsstreven van de wijkverpleging. Methodologisch is hij streng in de leer en wil graag afdoende wetenschappelijke garanties vooraf.

Hij is wars van dubbelwerk en houdt niet van activiteiten in het teken van de waan van de dag (imago).

En last but not least: hij is aardig in menselijke omgang en houdt van gezelligheid. 


\section{Tot slot}

Crebolder nadert nu ook het eind van de bestuurstermijn van STOOM. STOOM is hem veel dank verschuldigd. Gelukkig kent STOOM een zogenaamd seniorenconvent: de vergadering van oud-bestuurders, waar adviezen aan het bestuur worden geformuleerd.

Wij hopen Crebolder daar straks weer te ontmoeten met een even grote vitaliteit en strijdlust voor kwaliteit en professionaliteit in de eerste lijn als voorheen.

Prof. dr. J. van Londen is voorzitter van STOOM. 


\section{$T$ ransmurale zorg: van DCM naar BZe VII, azM 1979-2002}

Peter Pop.

\section{Inleiding}

In Nederland staat in een aan (af)kortingen 'rijke' gezondheidszorg transmurale zorg al geruime tijd volop in de belangstelling. Het doel van deze zorg is tweeledig: vergroten van de doelmatigheid van zorg en het realiseren van zorg op maat.

In de gezondheidszorg zijn veranderingen aan de orde van de dag. Gedachten, ideeën en plannen die aan deze veranderingen ten grondslag liggen vloeien voort uit een toename van de zorgvraag (meer technische mogelijkheden, vergrijzing van de bevolking), een herschikking van het zorgaanbod (met een doorbraak van de muren tussen eerste en tweede echelon), verandering in het verzekeringsstelsel (grotere verantwoordelijkheid voor de verzekeraar en meer vraag om 'value for money'), een sociaal-economisch en politiek klimaat met aandacht voor de patiënt (zorg op maat) en doelmatigheid van de zorg.

Aan principes van transmurale zorg/ketenzorg en managed care/disease management ontleende instrumenten zijn bruikbaar om aan gewenste veranderingen in de zorg gestalte te geven. Barrières op de weg naar aan eisen van 2002 beantwoordende zorg zijn veelal aanwezig in de vorm van samenwerkings- en organisatieproblemen, belangentegenstellingen, beperkingen in deskundigheid, kennis en vaardigheden, tekorten aan menskracht en financiering.

In Maastricht werd met de ontwikkeling van transmurale zorg al een begin gemaakt in de jaren zeventig. Het Diagnostisch Centrum Maastricht (DCM) startte in Nederland als een experiment; de laatste jaren werd vorm gegeven aan Behandel-Zorg-eenheid (BZe) VII Transmurale Zorg. De capaciteitsgroep Huisartsgeneeskunde heeft bijdragen geleverd in de diverse fasen van ontwikkeling van deze transmurale zorg.

\section{Voorgeschiedenis}

In 1979 startte op verzoek van het Ministerie van Volksgezondheid en 
Milieuhygiene in Maastricht in Ziekenhuis St Annadal het experiment DCM met twee doelstellingen: 1 . Het bevorderen van een doeltreffend en doelmatig gebruik van diagnostische voorzieningen van het ziekenhuis door huisartsen. 2. Verbetering van communicatie en samenwerking tussen huisarts en specialist.

$\mathrm{Na}$ een succesvol experiment vond op verzoek van de huisartsen continuering van het DCM plaats in de vorm van de Stichting Diagnostisch Coördinerend Centrum (DCC). Uitbreiding van doelstellingen en activiteiten vond plaats.

In 1994 verzocht de Raad van Bestuur (RvB) van het academisch ziekenhuis Maastricht (azM) aan het DCC om structurering en uitbouw van transmurale activiteiten te realiseren. Het DCC nieuwe stijl kreeg de naam Transmuraal en Diagnostisch Centrum (T\&DC). In 1995 werd door de besturen van drie diagnostische centra (Amersfoort, Helmond en Maastricht) de Federatie Medisch Coördinerende Centra (FMCC) opgericht om ruimer verbreiding te geven aan in genoemde centra ontwikkelde ideeën en activiteiten. Het streven is om MCC's te laten fungeren als uitvoerende organen van de coördinatie van transmurale activiteiten in een regionaal zorgnetwerk.

Vanaf 1999 werden vanuit het T\&DC plannen ontwikkeld om de samenwerking met de externe partners te intensiveren. Dit leidde in juli 2000 tot het oprichten van BZe Vil Transmurale Zorg waarmee status en inhoud werd gegeven aan transmurale zorg en met name aan de invulling van ketenzorg. Betrokken partijen hebben zich via samenwerkingsverbanden en strategische allianties verplicht om daadwerkelijk invulling te geven aan voorgenomen plannen.

\section{Voorwaarden voor transmurale zorg}

In het kader van doelstellingen betreffende het ondersteunen van de huisarts in het diagnostisch handelen, de verbetering van communicatie en samenwerking tussen huisarts en specialist, de ontwikkeling van transmurale gezondheidszorgprojecten, de uitvoering van wetenschappelijk onderzoek gericht op vraagstellingen aangaande de relatie eerste-tweede 
lijnsgezondheidszorg alsmede transmurale zorg en het geven van onderwijs met behulp van gegevens voortkomend uit analyses van diverse (transmurale) zorg-en onderzoekactiviteiten, werden in de loop der jaren in discussies bij herhaling uitgangspunten vast- en bijgesteld voor programmatisch uit te voeren activiteiten en projecten. Het betrof zowel organisatorische als werkinhoudelijke voorwaarden, te stellen aan het functioneren van ziekenhuis, instellingen van thuiszorg, specialisten, huisartsen, ziektekostenverzekeraars, overheid en patiënten.

Zo werd bijvoorbeeld gesteld dat transmurale zorg een vertaling moet vinden in het beleid van het ziekenhuis. Naast een strategisch plan is er een medisch beleidsplan, waarin op het niveau van vakgroepen transmurale zorgactiviteiten worden gepland. Specialisten dienen op consultbasis ook buiten het ziekenhuis aanspreekbaar te zijn (gezamenlijk consult in de huisartspraktijk en in de thuissituatie, telefonische consultatie). Transmurale zorg vraagt van de huisarts een verdere ontwikkeling van gezondheidscentra, waarbij functiedifferentiatie mogelijk is.

Ziektekostenverzekeraars kunnen bij de ontwikkeling van zorgprojecten een initiërende rol spelen vanuit kennis van diverse zorgactiviteiten in de regio. Samenwerking van professionals en organisaties binnen en over de grenzen van afdelingen en instellingen heen moet plaats vinden. Zorgprocessen dienen te worden herontworpen. Kennis van omschreven strategieën en methoden (Business Proces Redesign, Disease Management, Integraal Kwaliteitsmanagement) is hiervoor noodzakelijk. Voor de ontwikkeling van transmurale zorg dienen financiële middelen geoormerkt ter beschikking te staan. De overheid zal in deze een aanmoedigingsbeleid (investering in projecten, bonussen) moeten voeren. Betere voorlichting aan patiënten dan tot dusver dient een reële zorgvraag (zorg afgestemd op behoeften van de individuele patiënt) mogelijk te maken. 


\section{Activiteiten en projecten}

In de loop der jaren zijn in het kader van genoemde doelstellingen diverse activiteiten en projecten ontwikkeld. Evaluatie heeft plaats gevonden via wetenschappelijk onderzoek in samenwerking met de vakgroepen Huisartsgeneeskunde, Economie van de Gezondheidszorg, Medische Informatica, Methodologie \& Statistiek, Epidemiologie en de Werkgroep Onderzoek Kwaliteitsbevordering Huisartsgeneeskunde KUN. Diverse publicaties (nationaal en internationaal) en proefschriften zijn verschenen. Navolgend worden enkele voorbeelden hiervan gegeven.

Persoonlijke feedback aan de huisarts ten aanzien van diagnostisch onderzoek

In 1985 startte dit project met als doelstelling een meer rationeel diagnostisch aanvraaggedrag van huisartsen te bevorderen. Deze feedback ten aanzien van diverse vormen van diagnostiek (laboratoriumonderzoek, beeldvormende diagnostiek, ECG, pathologische anatomie enz.) vond plaats op basis van werkafspraken (indicaties voor aanvraag van tests, richtlijnen voor diagnostiek bij omschreven klachten/symptomen/ziektebeelden) en op basis van principes van medische besliskunde. Een en ander resulteerde in een kwalitatieve verbetering van het aanvraaggedrag en een aanzienlijke besparing van kosten van diagnostisch onderzoek. Deelactiviteiten van dit project waren de mogelijkheild van gestructureerde telefonische consultaties tussen huisarts en specialist en geautomatiseerde reminders en feedback (GRIF-project). Inbedding van deze structuur in het VATU-project (van aanvraag tot uitslag) en het koppelen vam het ziekenhuisnetwerk met het

huisartsinformatiesysteem biedt naast een verbetering van de mogelijkheden voor diagnostiek tevens de infrastructuur voor geprotocolleerde behandelingsstrategieën.

Gezamenlijk consult huisarts-specialist in de spreekkamer van de huisarts

De doelstelling van dit consult is een toename van kennis en 
technische vaardigheden van de huisarts bij het onderzoek van patiënten met frequent in de huisartspraktijk voorkomende problemen. Onderzoek werd verricht naar de resultaten van o.a. het gezamenlijk consult huisarts-orthopedisch chirurg. De gezamenlijke spreekuren blijken organisatorisch goed uitvoerbaar en dragen bij aan een gerichter en doelmatiger verwijsbeleid van de huisarts. De kostendaling als gevolg van de afname van het aantal verwijzingen en verrichtingen is groter dan de kosten verbonden aan het gezamenlijk consult (inclusief honorarium voor huisarts en specialist). Er vonden eveneens gezamenlijke consulten van huisartsen met cardioloog, reumatoloog en dermatoloog plaats. In het laatste project was er tevens sprake van een teleconsult, waarbij vanuit de huisartspraktijk via de computer dermatologische beelden verzonden werden aan de huidarts. Bij onderzoek bleek ook bij deze gezamenlijke consulten sprake te zijn van een duidelijke afname van diagnostiek en poliklinische verwijzingen. In overleg met de zorgverzekeraar VGZ werd besloten om deze vorm van gezamenlijke consulten als reguliere zorg te implementeren volgens het zogenaamde Carrousel-model.

Hierbij 'draait' de huisarts een jaar lang mee met een bepaald specialisme en "springt" daarna over naar een volgend.

Avond-, nacht-en weekenddienstregeling huisartsen

In januari 2000 startte deze dienstregeling, waarbij op doordeweekse dagen tussen 18.00 en 24.00 uur en in de weekenden en op feestdagen van 's morgens 08.00 tot 16.00 uur en vanaf dit tijdstip tot middernacht telkens twee huisartsen op de post dienst doen en één huisarts visites rijdt in een daarvoor aanwezige auto met chauffeur. In deze regeling doen huisartsen maximaal acht uren aaneen dienst, hetgeen leidt tot een aanzienlijke reductie van het aantal diensturen. In deze huisartsenpost annex de Spoedeisende hulp (SEH) van het azM worden alle patiënten behandeld, die zich zonder verwijzing op of via de SEH aandienen. Het project met een looptijd van twee jaar wordt gefinancierd door azM en de zorgverzekeraars VGZ/CZ. Het azM financiert en garandeert tevens de personele ondersteuning en huisvesting. 
Een analyse van de patiëntenstromen naar de huisartsenpost en de daarmee samenhangende effecten op de azM-organisatie zullen leiden tot het besluit al dan niet met de (bijgestelde) post door te gaan na afloop van de projectperiode.

Regionaal disease management model voor de diabeteszorg Het per januari 2000 in praktijk gebrachte disease management model voor diabeteszorg is een implementatie van de shared care zorgmodellen diabetes mellitus: Gezamenlijk consult huisartsinternist en Transmurale diabetesverpleegkundige. Het doel van het model is om de kwaliteit van de diabeteszorg binnen de regio Heuvelland te optimaliseren door een integrale aanpak van zorg binnen de bestaande budgetten. Het model geldt voor alle personen met diabetes bij wie een kernteam bestaande uit huisarts/praktijkverpleegkundige, diabetesverpleegkundige en internist-endocrinoloog verantwoordelijk is voor de zorgverlening. De toewijzing van deelverantwoordelijkheden is vastgelegd in een multidisciplinair protocol; evenzo de indeling in de drie zorgroutes: internist, diabetesverpleegkundige en huisarts/praktijkverpleegkundige. Deskundigheidsbevordering, ICT, benchmarking en transparantie hebben binnen het model een duidelijke prioriteit.

\section{Project Praktijkverpleegkundige Maastricht,}

Het in samenwerkingsverband tussen de Stichting

Gezandheidscentra Maastricht, de Stichting Groene Kruis Heuvelland, de Universiteit Maastricht en het T\&DC opgezette project

Praktijkverpleegkundige Maastricht heeft ten doel de huisartsen in de praktijkuitoefening te ondersteunen door de inzet van praktijkverpleegkundigen. Beoogd wordt om de kwaliteit van zorg aan chronisch zieken te verbeteren en de werkdruk van huisartsen te verlichten. Gestart werd met spreekuren en huisbezoeken t.a.v. de aandachtsgebieden diabetes, astma/COPD en complexe zorg voor ouderen in drie geacademiseerde gezondheidscentra. Verwacht wordt o.a. dat patiënten met astma/COPD door bezoeken aan de praktijkverpleegkundige minder gaan roken en een beter 
medicatiegebruik zullen tonen. Een en ander zal bewerkstelligen dat er minder exacerbaties van het longlijden en een betere longfunctie zullen zijn. De resultaten van dit project worden ingebracht in discussies over een verdere implementatie van praktijkondersteuning door inbreng van praktijkverpleegkundigen.

\section{Transmuraal Zorgmodel CVA}

In dit zorgmodel (stroke service model genoemd) is de zorg geprotocolleerd vanaf het moment dat het CVA optreedt tot en met de zorg na ontslag uit het zlekenhuis. Een goede samenwerking tussen alle zorgaanbieders uit de eerste en de tweede lijn is hiervoor vereist. Via implementatie van dit zorgmodel worden patiënten sneller opgenomen en gaan er meer patiënten na ziekenhuisopname naar huis. Samenwerkingsovereenkomsten werden o.a. afgesloten met verpleeghuizen en het Revalidatiecentrum Hoensbroek. Uit onderzoek blijkt dat de continuiteit en kwaliteit van zorg verbeterd zijn. Na opname in azM kan de patiënt na aanmelding voor dit type zorg binnen to tot 14 dagen worden overgeplaatst voor vervolgzorg. De duur van verblijf in het ziekenhuis is hierdoor sterk bekort.

\section{Centrum voor Ontwikkeling Palliatieve Zorg Maastricht}

Het COPZ-M is één van zes centra in Nederland die met steun van het ministerie van VWS zijn opgericht om de kwaliteit van de palliatieve zorg voor patiënten in een terminale fase te optimaliseren. Dit vindt plaats via een consultatief palliatieteam, deskundigheidsbevordering, onderzoek en netwerkontwikkeling. Het palliatieteam is een interdisciplinair team met vertegenwoordigers uit de verschillende velden van de gezondheidszorg die expertise hebben op het terrein van de palliatieve zorg. Het team werkt transmuraal (adviseert t.a.v. patiënten in het ziekenhuis, verzorgingshuis, verpleeghuis, hospice en thuis). Het fungeert als aanspreekpunt voor complexe vragen en verricht telefonische zowel als bedside consulten. Het palliatieteam neemt de zorg niet over, maar adviseert mondeling en schriftelijk aan de consultvrager. Zonodig kan ter plekke instructie worden gegeven t.a.v. technische handelingen. Patiëntenzorg en onderzoek zijn nauw met elkaar verweven. Het betreft o.a. de evaluatie van het 
palliatieteam, van de autonomie van de patiënt en van zorgbehoeften en normatieve opvattingen over 'goed sterven'.

\section{Farmacotherapeutisch Transmuraal Overleg}

Het Maastrichtse FTTO is één van de acht proeftuinen farmacie, gesubsidieerd door VWS, die in Mei 1999 van start gingen. Er bestaat een samenwerkingsverband van het az $M$ met vierhonderd voorschrijvende artsen en vier apothekers, de negentig huisartsen van de regio Heuvelland, de dertig apothekers van Maastricht, het T\&DC en de zorgverzekeraars. Er werden richtlijnen ontwikkeld voor het gebruik van antibiotica, astma- en COPD-middelen en cholesterolverlagende middelen. Gestart werd tevens met richtlijnen voor het gebruik van antidepressiva. Vertaling van op schrift gestelde richtlijnen in reminderteksten ingevoerd in een computerreminder systeem vindt plaats. Er wordt direct feedback gegeven op het voorschrijven van artsen (indicatie, keuze en dosering van middelen). Via onderzoek wordt nagegaan in hoeverre deze aanpak daadwerkelijk effectief en doelmatig is.

\section{Appropriateness Evaluation Protocol}

Met behulp van het AEP kan bij in azM opgenomen patiënten op indexdagen aan de hand van een criterialijst worden nagegaan of zij op die dag terecht in het ziekenhuis verblijven. Als het klinisch verblijf niet noodzakelijk is, wordt bekeken of er sprake is van een structureel probleem, zoals wachttijd voor een gepland onderzoek, voor een consult of operatie en/of vertraagd ontslag (geen mogelijkheid tot overplaatsing, problemen in de thuissituatie). Wanneer er sprake is van structurele problemen, dan wordt nagegaan of hiervoor een oplossing mogelijk is. Bij frequent voorkomende wachttijden voor bijv. CT-scanonderzoek kunnen richtlijnen voor indicaties voor aanvraag van onderzoek met feedbackprocedure voor aanvragers worden opgesteld, kan gebruik van de apparatuur ook in de avonduren worden gepland enz. Onderzoek vindt plaats naar effecten van gebruik van het AEP op de afdelingen Interne Geneeskunde, Obstetrie en Verloskunde en Heelkunde. 


\section{Projecten Thuiszorgtechnologie}

Op basis van bestaande wachtlijstproblematiek wordt onderzocht in hoeverre het mogelijk is om omschreven categorieën patiënten vervroegd te ontslaan en in een thuissetting verder te behandelen met behulp van technische hulpmiddelen. Een onderzoek "Infuusbehandeling thuis" werd in 1996 succesvol afgerond en in de praktijk van alledag geïmplementeerd. Voor omschreven patièntengroepen werden protocollen opgesteld (pijnstillende medicatie bij terminale patiënten met kanker, gecombineerde dopamine-lasix-infusie bij chronisch hartfalen, mannitol bij sympatische reflexdystrofie enz).

Op het gebied van clinical outreach en thuiszorgtechnologie worden ook andere projecten uitgevoerd zoals het herhaaldelijk toedienen van bloedtransfusies in de thuissituatie bij specifieke groepen patiënten en een MTA-onderzoek naar mogelijkheden voor en effecten van thuisbehandeling van pasgeborenen met icterus neonatorum.

\section{Bespreking}

De in het T\&DC met o.a. genoemde activiteiten en projecten verkiregen expertise en ervaring zijn de basis waarop BZe VII Transmurale Zorg nieuwe zorgvormen ontwikkelt waarbij de gehele zorgketen betrokken is. Door de aard van deze nieuwe activiteiten zullen op groter schaal patiëntenstromen worden beïnvloed. Verandering van vormgeving en uitbreiding van mogelijkheden van dit instituut voor transmurale zorg geven aan dat het az $M$ hieraan veel belang hecht. Inbreng van belanghebbende partijen in het beleid wordt geboden door vertegenwoordiging van alle partijen uit de zorgketen in een Professionele Advies Raad (PAR). Hiermee start een periode waarin het az $M$ meer gericht is op het directe verzorgingsgebied. Het is de ambitie van azM om zowel de regionale patiëntenzorg als de academische patiëntenzorg in balans met elkaar te brengen, waarbij omgevingsgerichtheid, doelmatigheid en continuiteit van de zorg en patiëntgerichte zorg centraal staan. Door de capaciteitsgroep Huisartsgeneeskunde wordt al geruime tijd 
in discussie met azM gesproken over inbedding van Huisartsgeneeskunde in de structuur van azM. De in de academische werkplaatsfunctie van Huisartsgeneeskunde aanwezige infrastructuur en deskundigheid voor uitvoering van onderzoek en zorgvernieuwingsprojecten kunnen een belangrijke bijdrage leveren aan verwezenlijking van de doelstellingen van BZe VII Transmurale Zorg. Structurele samenwerking van azM, de capaciteitsgroep Huisartsgeneeskunde en het netwerk van academische. huisartspraktijken wordt bevorderd door huisvesting (letterlijk en figuurlijk) binnen de organisatiestructuur van BZe VIll. De verantwoordelijk leidinggevenden spelen een actieve rol in de Partnerraad, de Scientific Board, de managementstructuur op afdelingsniveau en al langere tijd bestaande overlegstructuren zoals de Stafraad en de Stuurgroep Transmurale Zorg. Vanuit Huisartsgeneeskunde vervult Crebolder hierin reeds jaren een actieve rol. Samenwerkingsrelaties met de huisartsen van Maastricht zullen verder worden uitgebouwd. De goed functionerende centrale huisartsenpost voor de avond-, nacht- en weekenddiensten van de huisartsen vanuit de SEH van azM is hiervan een voorbeeld. De verdere ontwikkeling van samenwerkingsverbanden van huisartsen onderling zoals gezondheidscentra, waarbinnen functiedifferentiatie van huisartsen mogelijk is, lijkt in dit kader van essentieel belang. In april 2001 heeft het azM een strategische alliantie gesloten met het Groene Kruis Heuvelland. Een nauwere, samenwerking op het gebied van de patiëntenzorg en het ontwikkelen van verpleegkundige concepten vindt zijn vertaling in zorgarrangementen voor verschillende patiëntencategorieën waarin het gehele zorgtraject van vóór de ziekenhuisopname tot na het ontslag is geregeld. Ook de afstemming tussen taken van de verpleegkundige van het Groene Kruis, de verpleegkundige van het ziekenhuis en de praktijkverpleegkundige van de huisarts is een aandachtsgebied van belang. In deze is tevens realisatie van een hechte samenwerking met verpleeg-en verzorgingshuizen noodzakelijk.

De door het T\&DC met de ziektekostenverzekeraars opgebouwde communicatie en samenwerking zal worden geïntensiveerd.

Door participatie in diverse overlegstructuren zal de 
ziektekostenverzekeraar een rol van betekenis blijven vervullen in beleidsvorming, planning en ondersteuning van uitvoering van activiteiten.

Het zal nog veel inspanning kosten om de azM-organisatie van dit moment in lijn te brengen met de geschetste ontwikkeling. Ketenzorg vereist goede communicatie en samenwerking van alle hieraan deelnemende instellingen en personen. Wanneer vanuit gevoelens van onvrede met het functioneren van de gezondheidszorg van de laatste jaren en op basis van geschetste ideeën en plannen de will tot verandering aanwezig is, dan is hiermee een eerste stap op een lange weg naar realisatie van een en ander gezet. Samenwerking van organisaties en professionals binnen en over de grenzen van disciplines, afdelingen en instellingen heen dient plaats te vinden. Dat de inzet van Crebolder gedurende veel jaren mede geleid heeft tot het scheppen van voorwaarden op basis waarvan BZe VII Transmurale Zorg succesvol kon starten als een transmuraal instituut ter bevordering van doelmatige zorg die aansluit aan de wensen van de patiënt, stemt tot tevredenheid en dank.

\section{Literatuur}

1 Beusmans G, Velde E van der, Wolters C, Boiten J. Het transmuraal zorgmodel CVA in de regio Maastricht. Med Contact 1997; 42: 1314-7.

2 Beusmans GHNI, Crebolder HFJM, Ree J van. Zorg voor chronisch zieken. Praktijkverpleegkundigen breed inzetten. Med Contact 2001; 56: 259-62.

3 BZe VII Transmurale Zorg Academisch Ziekenhuis Maastricht. Informatiebrochure over transmurale activiteiten in de regio Heuvelland. Maastricht: azM, 2001.

4 Crebolder HFIM, Root JMH op 't. Een transmuraal onderwijsprogramma vanuit de huisarts-praktijk. Ned Tijdschr Geneeskd 1994; 138: 1486-9.

5 Pop P, Spreeuwenberg C. Transmurale zorg in de regio Maastricht. Van Diagnostisch Coördinerend naar Transmuraal \& Diagnostisch Centrum. Med Contact 1998; 53: 91-4. 
6 Smeets $P, P o p$, Verheggen F. Beoordeling van de noodzaak tot ziekenhuisverblijf: de mogelijkheden van het 'appropriateness evaluation protocol" nader onderzocht. Med Contact 1997; 24: 757-60.

7 Smeets P. Complexe medisch-technische zorg. Ontwikkeling, implementatie en evaluatie van infuus thuis (proefschrift). Maastricht: Universiteit Maastricht, 1999.

8 Spreeuwenberg C, Pop P. Transmurale zorg. In: Handboek Transmurale Zorg. Maarssen: Elsevier/Bunge; 2000.

9 Vierhout WPM. Het gezamenlijk consult van huisarts en specialist in de eerste lijn (proefschrift). Maastricht: Rijksuniversiteit Limburg; 1994.

10 Vierhout W, Knottnerus J, Ooij A van, Crebolder H, Pop P, Wesselingh-Megens A, Beusmans $G$. Effectiveness of joint consultation session of general practitioners and orthopaedic surgeons for locomotor-system disorders. Lancet 1995; 346: 990-4.

11 Vlek JFM, Vierhout WPM, Pop P. Gezamenlijk consult huisartsspecialist in de huisartspraktijk. Tijdschr. Huisartsgeneeskd 1997; 14: 15-8.

12 Winkens R. Improving test ordering in general practice (proefschrift). Maastricht: Rijks-universiteit Limburg; 1994.

13 Winkens R, Pop P, Buyter-Maassen A, Grol R, Kester A, Beusmans $G$, Knottnerus J. Randomised controlled trial of routing individual feedback to improve rationality and reduce numbers of test requests. Lancet 1995; 345: 489-502.

Prof. dr. P. Pop is internist. Tot vorig jaar was hij hoofd van het T\&DC in het $\mathrm{azM}$. 


\section{Harry en HAG: Paradigma in persoon}

George Beusmans.

Job Metsemakers.

Continue, integrale en persoonlijke zorg. Woudschouten is Harry op het lijf geschreven.

Een van de leiders van de bende van Gideon. Een gedreven leider stimulerend, motiverend maar gestreng. Je diende te doen waar je voor stond. Waar je voor wilde staan, dat moest je zelf bepalen.

Harry heeft zich voor veel zaken in het bellang van de huisartsgeneeskunde ingezet. Eigenlijk werd hij in 1986 als ELOC, Eerste Lijn Onderwijs Coördinator, bij de Faculteit Geneeskunde aangesteld. Samen met de Tweede Lijns Onderwijs Coördinator zou hij het practisch medisch onderwijs moeten overzien en sturen. Het waren echter vage gedachten die Harry de gelegenheid gaven zich in te zetten voor de plaatsbepaling en ontwikkeling van de Huisartsgeneeskunde. Een unieke kans zag hij hier liggen in de verdere academisering van huisartspraktijken, niet alleen ten behoeve van onderwijs- en onderzoeksdeelname maar ook ten behoeve van gezondheidszorgontwikkeling.

Toen Harry van het Gezondheidscentrum Withuis naar Maastricht kwam was er over academisering al heel wat geschreven en gepraat. Een workshop, plannen van Wim Brouwer (de eerste hoogleraar Huisartsgeneeskunde in Maastricht), plannen van medewerkers van de capaciteitsgroep Huisartsgeneeskunde ("de vier baarden"), plannen van enkele huisartsen in opleiding en een rapport van een door de minister ingestelde "Commissie Sikkel". Maar concreet was het in 1985 nog alleen maar in de Huilsartspraktijk Geulle, waar sprake was van een eerste samengaan van gezondheidszorg, onderwijs en onderzoek. Het Gezondheidscentrum Withuis volgde evenals een aantal praktijken waarmee al langer samenwerking bestond. Geleidelijk ontstond het later door R. Kocken in zijn proefschrift beschreven Huisartsgeneeskundig Academiseringsnetwerk Maastricht (HAM). De huisartsen uit deze praktijken verrichtten in het kader van de samenwerking taken op het gebied van opleiding tot 
arts, de opleiding tot huisarts, registratie voor wetenschappelijk onderzoek en wetenschappelijk onderzoek zelf. Maar in feite was het een gedeeltelijke academisering, omdat de gezondheidszorg niet benoemd werd. De Faculteit Geneeskunde betaalde voor onderwijs, registratie en wetenschappelijk onderzoek, maar stelde geen geld beschikbaar voor gezondheidszorgontwikkeling. Harry vond dat onbegrijpelijk, omdat de academisering Huisartsgeneeskunde niet zou kunnen bestaan zonder die ontwikkelingsfunctie in samenhang met de onderwijs-en onderzoekstaak. Waarom zou de academische huisartsgeneeskunde geen middelen krijgen? Moest dat uit de Rijksbijdrageregeling Academische Ziekenhuizen? Diende er een aparte regeling voor Huisartsgeneeskunde komen? Ook daa rover hebben landelijke commissies rapporten geschreven, waarin voorstellen ter financiering gedaan werden. In verhouding tot de Rijksbijdrage Academische Ziekenhuizen gaat het om bescheiden bedragen, maar ook hier liet en laat het antwoord lang op zich wachten.

Harry besloot tot een andere aanpak. Hij besefte dat wachten op geld uit Den Haag nog lang zou kunnen duren en dat opeisen van een deel van de Rijksbijdrage voor het azM ook tot eindeloze en mogelijk vruchteloze discussie zou leiden.

Maar als het azM nu eens een bescheiden bijdrage zou willen doen om het proces van gezondheidszorgontwikkeling op gang te brengen? Die vraag durfde Harry wel te stellen nadat hij in 1999 tijdens een bijeenkomst in Rijckholt aan Faculteit- en

Ziekenhuisbestuurders had laten zien wat het Netwerk Academische Huisartspraktijken Maastricht inhield. De verkregen middelen werden ingezet om onder andere verschillende vormen van gestructureerde patiëntbesprekingen in te voeren als onderdeel van een systeem van kwaliteitszorg. Daarnaast werden de huisartsen van de praktijken betrokken bij de opzet en uitvoering van zorginnovatieprojecten. Deze zouden immers de spil moeten worden van de inhoudelijke ontwikkelingen binnen de nieuw opgezette Behandel-en Zorgeenheid Transmurale Zorg (BZe VII), de opvolger van het Transmuraal- en Diagnostisch Centrum. Je zou kunnen zeggen dat daar de academische zorgontwikkeling van 
de academische praktijken gefaciliteerd wordt. Harry heeft met zijn standvastig volhouden en steeds maar opnieuw uitleggen van zijn denkbeelden toch de ruimte voor de academisering kunnen maken.

De gezondheidszorgontwikkeling kent een lange geschiedenis, waarbij Harry steeds de positie van de huisarts goed bewaakt heeft. Zorginnovatie, niet top-down maar bottum-up vanaf de praktijkvloer en in de loop der jaren hoe langer hoe meer in relatie tot andere hulpverleners. Diverse projecten werden geïnitieerd en opgezet. In eerste instantie nog sterk op de eerste lijn georiënteerd. Eind 80-er jaren het project "Samenwerkingsrichtlijnen thuiszorg voor CVA, incontinentie en dementie". Vanuit de eerste lijn werd het werkveld hoe langer hoe meer transmuraal geörienteerd. Op welke wijze konden de huisartsen optimaal samenwerken met de tweede lijn ? Projecten als "Infuuszorg thuis", " Transmuraal Zorgmodel Geriatrie" en "Transmuraal Zorgmodel CVA" werden opgezet en begeleid. In de jaren go vond verschuiving van zorgpatronen hoe langer hoe meer plaats: van ziekenhuis naar eerste lijn, van specialist naar huisarts en van arts naar verpleegkundige. Met name gold dit voor de zorg van chronisch zieken. Welke zorgstructuur, welk zorgmodel is het meest adequaat?

In het artikel "De huisarts van morgen. Van de Hoed en de thuisrand" ( $M C$ 1997; 52:284-6) wordt door Harry er met name vanuit organisatorische aspecten voor gepleit, dat samenwerking tussen huisartsen resulteert in huisartsenpraktijken onder een dak (HOED). Als voordelen met name stevige infrastructuur (o.a. mogelijkheid tot managementondersteuning), goede onderhandelingsbasis met andere zorgverleners, mogelijkheden tot functiedifferentiatie, zowel inhoudelijk als wat tijdsaspecten betreft. De huisartsgeneeskundige zorg wordt tot huisarts-voorziening, waarbinnen door meerdere, in de toekomst zeker deels parttime werkende, huisartsen adequate huisartsgeneeskundige zorg wordt gewaarborgd.

Op hoe de zorg wat samenwerkingsaspecten betreft vorm te geven wordt in het artikel "Zorg voor chronisch zieken: praktijkverpleegkundigen breed inzetten" (MC 2000; 56:259-62) nader ingegaan. De gewenste horizontale en verticale substitutie van zorg, met name bij de zorg 
voor chronisch zieken, vraagt om gestructureerde en geprotocolleerde samenwerkingsafspraken tussen de meest betrokken hulpverleners specialist, verpleegkundig specialist, huisarts en praktijkverpleegkundige. In het naar voren gebrachte QUATTRO-model neemt de huisarts een duidelijke plaats in. Specifieke kenmerken van de huisartsgeneeskunde, als bewaking van de bijna steeds aanwezige multimorbiditeit, persoonlijke en continue zorgverlening en kennis van de (familie)geschiedenis van de patiënt kunnen voldoende tot hun recht blijuen komen.

Ter afsluiting een patiëntencasus uit de huisartspraktijk van een van ons, waarin de waarde van de kennis van de geschiedenis van de patiënt en het gevaar van beleidsbepaling op basis van incidentele waarneming duidelijk wordt. Harry kon aan zo'n casus groot plezier beleven. Er bestond haast geen betere ontspanningsoefening voor hem.

Die ochtend bezocht dhr. V. mijn spreekuur. Dhr. V. ken ik als patiënt reeds sedert een groot aantal jaren. Diverse klachten, problemen en ziektebeelden zijn gepasseerd. Als zeldzaam ziektebeeld midden tachtiger jaren: Lamblia infectie, aanleidinggevend tot een geringe vloka-trofie met o.a. een lactase deficiëntie.

Hiervan is patiënt steeds hinder blijven houden. Niet alleen lichamelijk maar ook geestelijk raakte patiënt in de knel door een gedwongen ontslag als boekhouder in 1990 waardoor hij in de WW geraakte. Psychotherapie was tijdelijk noodzakelijk. Daarna is het een tijdlang redelijk gegaan. Door de persisterende buikklachten evenwel, waarop patiënt gefixeerd bleef, werd in 2000 wederom een psychotherapeutische interventie zinvol geacht. Patiënt onderging een gedegen neuropsychologische analyse, waarvan de uitslag luidde: Patiênt voldoet aan de kenmerken van een paranoilde persoonlijkheidsstoornis en heeft hierbij schizoïde trekken (DSM 4 DIAG 301.0). Eveneens is er sprake van alcohol-en nicotine-abusus. Patiënt vertelde op het spreekuur het rapport ingezien te hebben en zich zorgen te maken voor zijn kinderen, die met zo'n

"vadergeschiedenis" belast zouden kunnen worden. Zijns inziens 
waren enkele zaken, in zijn behoefte om alles eerlijk naar voren te brengen, letwat eenzijdig geïnterpreteerd. Die alcohol abusus sloeg op het gegeven, dat hij als militair vroeger wel eens een hele fles rum soldaat had gemaakt. Zo ook de nicotinevergiftiging, omdat hij wel eens een pakje shag per dag rookte op patrouille op de hei. De paranoïde persoonlijkheidsstoornis berustte waarschijnlijk op het gegeven, dat zijn vroegere wiskundeleraar hem met klem op het hart had gedrukt nooit iemand helemaal te vertrouwen. Tenslotte was hij als schizoid bestempeld op basis van zijn rancuneus gedrag naar aanleiding van het onterechte ontslag en zijn gang naar de WW. Ik was blij, dat ik hem al jaren kende. Een gemakkelijke patiënt was hij zeker niet, maar dit rapport motiveerde mij, als zijn huisarts, voor hem in het verweer te gaan. Wie zou het anders kunnen? Voor veel patiënten kunnen we als huisarts een unieke functie vervullen.

Harry, jij zou ook zeker voor hem door het vuur gegaan zijn. Zo was je als praktizerend huisarts en zo ben je gebleven: Een huisarts in hart en ziel, in daad, woord en geschrift.

Good luck.

Je hebt het waargemaakt en verdiend.

Dr. G. Beusmans en dr. J.F.M. Metsemakers zijn beiden Universitair Hoofddocent bij de Capaciteitsgroep Huisartsgeneeskunde van de UM. 


\section{Harry Crebolder en het azM}

Jan Carpay en Lou Brans Brabant.

Harry werd in 1987 benoemd tot hoogleraar Huisartsgeneeskunde aan de Faculteit Geneeskunde van de Rijksuniversiteit Limburg, nu Universiteit Maastricht.

Deze benoeming werd uiteraard ook in het az $M$ waargenomen, maar leidde aanvankelijk niet tot intensievere contacten tussen de capaciteitsgroep Huisartsgeneeskunde en het azM.

In die tijd was het azM druk doende om zijn omgeving er van te overtuigen dat de regionale interpretatie van de Basisfilosofie tot een niet bepaald efficiënte organisatie van de academische zorgverlening zou leiden. En dat wat we met $z$ 'n allen ook mochten vinden van regionale spreiding van academische voorzieningen over de regio, we wisten dat noch het ministerie van O\&W noch het ministerie van WVC bereid zouden zijn om de daarvoor benodigde additionele middelen op tafel te leggen.

Wat hield die boodschap van het azM in? Die boodschap moet worden gezien tegen de achtergrond van alle schriftuur en beloften aan de regio rondom de komst van de achtste medische faculteit. Zij hield in dat met de realisatie van een daarbij behorend ander en niet traditioneel van opzet zijnde academisch ziekenhuis en de rol van de regionale ziekenhuizen en hun medische staven daarbij, de populariteitsprijs niet kon worden gewonnen.

Het was echter wel een noodzakelijke missie. Naar de regio diende kleur te worden bekend en diende te worden uitgesproken wat binnenskamers in ziekenhuis en faculteit al een gepasseerd station was. Het azM was met andere woorden, bezig met zijn positionering binnen de tweedelijns geneeskunde van die tijd en had daar en met het voltooien van de nieuwbouw, zijn handen meer dan vol aan.

Aandacht voor de eerstelijns geneeskunde en in het verlengde daarvan de capaciteitsgroep Huisartsgeneeskunde kwam tegen die achtergrond op dat moment op de tweede plaats. De contacten met de eerstelijn werden in die tijd vanuit het azM met name onderhouden vanuit het Diagnostisch Centrum gepersonifieerd in 
Peter Pop. Met het Diagnostisch Centrum, naderhand het Diagnostisch Coördinerend Centrum en inmiddels het Transmuraal \& Diagnostisch Coördinerend Centrum, profileerde het azM zich overigens meer dan de andere academische ziekenhuizen, richting eerstelijn. Niet alleen voor wat betreft de dienstverlening richting regionale huisartsen, maar ook ten aanzien van wetenschappelijk onderzoek op het grensvlak van de eerste en tweedelijns geneeskunde. In ieder geval zodanig dat van de zijde van het toenmalige Ministerie van $O \& W$ ten behoeve van het Diagnostisch Centrum een expliciete toevoeging plaatsvond aan de rijksbijdrage van het azM. Tot het moment waarop het Ministerie van OC\&W in het midden van de jaren negentig besloot om de Rijksbijdrage aan de academische ziekenhuizen te normeren is deze expliciete labeling van een deel van de Rijksbijdrage vanuit het Ministerie van O\&W gecontinueerd.

Zoals al vermeld waren de relaties tussen het azM en de capaciteitsgroep Huisartsgeneeskunde in die tijd niet zo intensief als op dit moment. Dat geldt zeer zeker ook voor de contacten tussen het azM en Harry.

Hoewell er vanaf het moment van benoeming uiteraard contacten waren tussen het azM en Harry, werden deze contacten pas echt intensief in 1998. In dat jaar werd in overleg tussen de Faculteit der Geneeskunde, de capaciteitsgroep Huisartsgeneeskunde, de regionale huisartsenvereniging en het az $M$ een conferentie belegd in Kasteel Rijckholt. Onderwerpen waren de academisering van de huisartsgeneeskunde, de mogelijke rol van het az $M$ en zijn medische staf daarin, de daarvoor benodigde financiële middelen en financiële mogelijkheden, alsmede de zienswijze van de regionale huisartsen op dat geheel.

Namens de verschillende partijen vonden op die conferentie inleidingen plaats, waaruit ieders positionering in relatie tot de genoemde onderwerpen viel af te leiden.

Harry hield daar op de hem bekende wijze een gloedvol betoog over het opgebouwde, tot in Brabant reikende, netwerk van academische praktijken, de noodzaak tot het zetten van volgende stappen in de 
academisering van deze praktijken en de daarvoor benodigde middelen. Naar analogie van de situatie bij de academische ziekenhuizen was zijn voorstel te komen tot de erkenning van een vertragingsfactor voor de patiëntenzorg in de academische huisartsenpraktijk tengevolge van onderwijs en onderzoek. De vertragingsfactor zou dan vervolgens weer bepalend zijn voor de hoeveelheid extra benodigde financiële middelen in een academische huisartspraktijk.

Zoals echter al aangegeven, iedere partij belichtte de onderwerpen vanuit zijjn eigen positionering en perspectief.

De bijdrage van het azM was, op zijn minst gezegd, voor Harry schokkend. Niet zo zeer qua inhoud als zodanig maar door de stellingname dat Harry's bijdrage weliswaar interessant was maar voor het ziekenhuis overigens niet relevant. Namens het azM werd naar voren gebracht dat het wat het ziekenhuis betrof, diende te gaan over de stroomlijning van de patiëntenzorglogistiek en dat in dat verband de organisatie van de ketenzorg het primaire belang was. De academische huisartsenpraktijken waren daarbij slechts één van de vele partijen. Deze als lichtelijke provocatie bedoelde uitspraak miste zijn uitwerking niet. Nog nooit heeft de Raad van Bestuur in de weken daarna zoveel toelichting achteraf moeten geven over een gedane uitspraak. Want je kunt van Harry zeggen wat je wil, maar als hij je éénmaal te pakken heeft, laat hij ook niet meer los.

Het was overigens wel het begin van een vruchtbaar traject van samenwerking tussen het azM en Harry. Als mijlpalen op dat traject zijn te noemen: de financiële bijdrage die vanuit de rijksbijdrage van het azM inmiddels wordt gegeven aan de capaciteitsgroep Huisartsgeneeskunde, de oprichting van de Behandel-en Zorgeenheid VII, met Harry als voorzitter, de erkenning van de huisartsgeneeskunde als medische afdeling van het az $M$ waardoor de mogelijkheid werd gecreëerd voor deelname aan het stafconvent van het azM, de tweede Rijckholtconferentie, de oprichting van de Huisartsenpost binnen de Spoedeisende Hulp van het azM en de lopende gesprekken over de verdere vormgeving van de relatie tussen de capaciteitsgroep Huisartsgeneeskunde en het azM. 
Het mag beslist twijfelachtig worden genoemd of deze resultaten zonder Harry allemaal bereikt hadden kunnen worden.

Natuurlijk gaan na verloop van tijd bepaalde aspecten van je overlegpartner opvallen. En er is wat overlegd met Harry.

Zo is hij nooit te beroerd om je bij de les te houden door zelf in je agenda voldoende ruimte voor zichzelf te reserveren. Daarvoor verschijnt hij veelal persoonlijk voor het bureau van de secretaresse. Ontsnappingsmogelijkheden zijn uitgesloten, want hij kijkt mee in de agenda en ziet ieder gaatje.

In een overleg is Harry altijd nadrukkelijk aanwezig. Hij zoekt de discussie, heeft altijd wel een mening of een visie ergens over en kan behoorlijk vasthoudend zijn. Daarbij speelt vaak zijn persoonlijke overtuiging of iets zus of zo zou moeten zijn, een centrale rol. Rationele argumenten van zijn opponenten ketsen vaak af op Harry's schild van persoonlijke overtuiging. Dat maakt het niet gemakkelijk om Harry op andere gedachten te brengen op het moment dat hij van lets overtuigd is geraakt.

Gelukkig is dat nooit z'n startpunt. Als Harry met voorstellen langs komt is zijn mening over het onderwerp veelal nog niet geheel uitgekristalliseerd. Hij heeft een notie waar hij heen wil, of hoe hij iets wil aanpakken, maar gebruikt zijn gesprekspartner nadrukkelijk om tot concretere invulling te komen of om zijn eigen gedachtenontwikkeling verder vorm te geven. Hij wil het overigens wel graag de volgende week gerealiseerd hebben.

Als Harry ergens aan mee doet, een functie vervult of een rol op zich neemt, zal hij er altijd voor honderd procent voor gaan, wil er dan ook volledig bij betrokken zijn en zijn invloed doen gelden.

Het resultaat is er dan ook meestal naar. Harry, op wat je de afgelopen jaren in Maastricht hebt opgebouwd, kun je met trots op terug kijken. Achteraf gezien had je misschien gewenst dat de intensivering van contacten met het az $M$ wat eerder van de grond waren gekomen. Echter, daar moeten dan niet alleen de anderen ook aan toe zijn, maar moeten ook de relevante omgevingsfactoren zodanig zijn dat win-win situaties kunnen worden gecreëerd. 
Misschien voor jou gevoel wat laat, maar uiteindelijk zijn we toch in dat stadium aanbeland.

Dr. J.J. Carpay is voorzitter van de Raad van Bestuur van het azM. Drs. L.J.H.M. Brans Brabant is lid van de Raad van Bestuur van het azM. 


\section{T ransmurale zorg: levenslang samenwerken}

Betty Meyboom-de Jong.

\section{Inleiding}

Samenwerking loopt als een rode draad door het professionele leven van Harry Crebolder.

Dat begon al in zijn studententijd toen wij, hij lid van het Veritas Bestuur en ik als lid van het UVSV Bestuur samen colleges en recepties (af)liepen. Harry was de eerste die promoveerde op een reeks artikelen gepubliceerd in Huisarts \& Wetenschap over de samenwerking in zijn huisartsgroepspraktijk het Withuis. (1) Harry sloot zijn carrière af als hoogleraar Huisartsgeneeskunde in Maastricht waar hij er onder andere in slaagde de transmurale samenwerking te ontwikkelen. Omdat Harry een belangrijke inspirator was bij tal van deze projecten en omdat transmurale zorg in de vorm van zorgketens de toekomst hebben nu het aantal patiënten met chronische ziekten stijgt, wil ik in dit stuk stilstaan bij de voorwaarden die noodzakelijk zijn om transmurale samenwerkingsprojecten te doen slagen en de succesvolle uitkomsten van deze projecten in de reguliere zorg te implementeren. Na de beschrijving van een model ontwikkeld op basis van de literatuur, probeer ik dit model te toetsen aan de transmurale samenwerking op het gebied van de diabeteszorg in Zwolle en aan de recent beschreven resultaten van de Edisse studie betreffende drie regionale experimenten met strokeservices. $(2,3)$

\section{Transmurale zorg}

Transmurale zorg is een 'container begrip' warin verschillende vormen zijn te onderscheiden: (4)

- Ziekenhuisverplaatste zorg. Hieronder valt de zorg aan patiënten die korter in het ziekenhuis verblijven dan men gewend was of de zorg aan patiënten waarbij een opname wordt voorkomen;

- Gedeelde zorg. Huisarts en specialist maken onderlinge afspraken over wie wanneer en waar bepaaide zorg op zich neemt ten aanzien van bepaalde patiëntencategorieën. Eventueel aan de hand van transmurale standaarden; 
- Consultaties of gezamenlijke consulten;

- Diagnostische voorzieningen, die door de tweede lijn voor de eerste lijn beschikbaar worden gesteld;

- Farmacotherapeutisch transmuraal overleg (FTTO);

- Huisartsbedden in een ziekenhuis;

- Gespecialiseerde verpleegkundigen ten behoeve van speciale patiëntencategorieën, meestal chronisch zieken. of zogenaamde liasons verpleegkundigen die contact legt tussen ziekenhuis en thuiszorg.

Transmurale zorg heeft enerzijds betrekking op zorginhoudelijke zaken zoals gezamenlijke en multidisciplinaire taakafbakening en samenwerking op de werkvloer. Anderzijds kent transmurale zorg een organisatorisch aspect, waarbij het gaat om structurele samenwerking tussen de organisatie van hulpverleners uit verschillende echelons. (5)

In 1995 is het begrip transmurale zorg door de toenmalige Nationale Raad voor de Volksgezondheid (NRV) gedefinieerd als "transmurale zorg omvat vormen van zorg die, toegesneden op de behoefte van de patiënt, verleend worden op basis van afspraken over samenwerking, afstemming en regie tussen generalistische en specialistische zorgverleners, waarbij sprake is van een gemeenschappelijk gedragen verantwoordelijkheid met expliciete deelverantwoordelijkheden'.(6) In 1998 omschreef Henk Mäkel, huisarts van professie, als directeur Patiëntenzorg van de Isalaklinieken te Zwolle transmurale zorg als 'het brengen van deskundigheid in de vorm van een persoon of kennis naar die plaats of instelling in de zorg, die het beste aansluit bij de behoefte van de patiënt'. (7)

Transmurale zorg is een reactief begrip dat zich afzet tegen de strikte echelonneringsgedachte, die in 1974 . werd ontwikkeld door wijlen Staatssecretaris Hendriks. Om doelmatige, efficiënte en betaalbare zorg mogelijk te maken was het noodzakelijk de zorg van het tweede echelon - van de specialist en het te dure ziekenhuis - zoveel mogelijk over te dragen aan de huisarts in het eerste echelon: substitutie. In die tijd, wel gekenschetst met 'de huisarts als agoog', omarmde de huisarts als spil van de gezondheidszorg alle nieuwe taken die hem 
werden toebedacht. $\mathrm{Hij}$ verhelderde, bestreed somatische fixatie, controleerde patiënten op de pil elke drie maanden inclusief uitstrijkje, en voerde regelmatig doelgericht en langdurige gesprekken met patiënten, echtparen en hun families.

\section{Een model voor transmurale zorg}

In haar artikel beschrijft Bokken een theoretisch model.(8) Hierin wordt de totale zorg voor de patiënt als een zorgketen, een aaneenschakeling van activiteiten, beschouwd. Deze keten kan door allerlei dwarsverbindingen ook de vorm van een netwerk aannemen. Het primaire uitgangspunt is de patiënt met zijn klachten. $O p$ basis daarvan wordt het zorgproces gestart dat kan bestaan uit een enkel contact maar ook uit een weg langs diverse hulpverleners onder wie huisarts en specialist. Achtereenvolgens beschrijft Bokken een aantal niveau's van samenwerking:

1. Ad hoc contacten: Op het eenvoudigste niveau van samenwerking gaat het om ad hoc contacten. Hierbij is geen sprake van een structurele relatie. Bij deze vorm verloopt de communicatie tussen huisarts en specialist vaak niet optimaal.

2. Werkafspraken: Op een iets hoger niveau is er sprake van werkafspraken ten aanzien van het proces. Hierbij zijn meerdere mensen van beide partijen betrokken en er bestaat een vastgestelde relatie tussen partijen. Beide dragen verantwoordelijkheid voor een deel van het proces waarover beide partijen afspraken hebben gemaakt. Het maken van werkafspraken moet aan bepaalde voorwaarden voldoen.

3. Gemeenschappelijk medisch beleid: Op het derde niveau is er sprake van een gemeenschappelijk 'medisch beleid' dat betrekking heeft op de uitvoering van de geneeskundige zorg op middellange termijn. Er worden inhoudelijke werkafspraken gemaakt en criteria voor goede hulpverlening geformuleerd. In dit geval is er sprake van gezamenlijke verantwoordelijkheid voor het proces op deelgebieden. 
4. Procesintegratie: Op het vierde niveau is sprake van procesintegratie. Hierbij ligt de nadruk op het gezamenlijk ontwikkelen, organiseren, beheersen en besturen vam een deel van het zorgproces naast de gezamenlijke uitvoering van de zorg.

5. Gemeenschappelijke strategie: Op het vijfde niveau bestaat er een gemeenschappelijke visie. Hierbij draait het om het ontwikkelen van een gezamenlijke strategie waarbij overeenstemming wordt bereikt over zowel de doelstellingen als over de manier waarop het doel bereikt moet worden. Daadwerkelijke ontwikkeling van zorgvernieuwing vereist altijd samenwerking op dit niveau. Deze vorm is mogelijk wanneer huisartsen participeren in maatschapsof ziekenhuisbeleid maar ook wanneer specialisten participeren in het lange termijn beleid van een groepspraktijk of gezondheidscentrum.

6. Volledige integratie: Op het hoogste samenwerkingsniveau is sprake van volledige integrale medische zorg. Hierbij zijn eerste en tweede lijn organisatorisch niet meer te onderscheiden. Hiervan is sprake als huisartsen zijn opgenomen in een medische staf en de ziekenhuisorganisatie of als specialisten worden opgenomen in een huisartsgroepspraktijk of gezondheidscentrum.

\section{Samenwerken en beslissingen in de tijd}

Binnen de praktijkvoering van huisarts en specialist kunnen we drie soorten beslissingen onderscheiden: operationele, tactische en strategische beslissingen.(8)

Huisarts en specialist vervullen op al deze niveaus een rol: op operationeel niveau zijn zij uitvoerder van de geneeskunde en maken zij afspraken die direct gerelateerd zijn aan de uitvoering. Operationele samenwerking biedt de huisarts of specialist de mogelijkheid tot beïnvloeding van het uitvoerende deel van de geneeskunde of zorg op korte termijn (kleiner dan 1 jaar). Op tactisch niveau zorgen zij voor directe supervisie op de uitvoering en afstemming van de geneeskundige activiteiten die gedurende langere tijd constant blijven Tactische samenwerking stelt de huisarts in staat de uitvoering en ontwikkeling en besturing van de zorg op de middellange termijn ( 1 tot 3 jaar te beïnvloeden). En op strategisch 
niveau bepalen zij de koers van hun praktijk binnen de omgeving. Strategische samenwerking heeft betrekking op de positie van bijvoorbeeld de huisartspraktijk als organisatie in zijn omgeving. Hier gaat het om beïnvloeding van de koers op langere termijn (langer dan 3 jaar).

\section{Noodzaak tot continuïteit van zorg}

In deze tijd is samenwerking tussen verschillende beroepsbeoefenaren in de zorg noodzakelijker dan ooit. De steeds ouder wordende patiënten lijden aan steeds meer aandoeningen. Multiple pathologie en de polyfarmacie toe nemen toe. Er is grote behoefte aan continuilteit van zorg en niet aan nog meer verschillende specialismen die ieder hun eigen risicofactor behandelen en hun eigen adviezen geven, die net een beetje anders zijn dan die van de specialist die vorige maand werd geconsulteerd. Veel patiënten zijn weliswaar mondiger geworden maar zieke, kwetsbare patiënten die zijn opgegroeid in een andere tijd hebben duidelijke, eenduidige, evidence-based adviezen, voorlichting en behandeling nodig, willen hun dokter hun lijf en leven kunnen toevertrouwen en niet moeten onderhandelen.

Dat geldt in het bijzonder voor patiënten met diabetes mellitus type 2 , de meest voorkomende chronische ziekte in de huisartspraktijk en voor patiënten die lijden aan de lichamelijke, psychosociale en cognitieve gevolgen van een beroerte. Voor deze patiënten is transmurale zorg noodzakelijk: continuiteit van zorg over de scheidingsmuren van de echelons heen, zowel van artsen. verpleegkundigen en verzorgenden en paramedici. Samenwerking vraagt om verandering van de huidige situatie waarbij huisarts en specialist gescheiden ten opzichte van elkaar werken en de nadruk meer ligt op leders deel dan op het totaal. De wil tot samenwerken bij de betrokken zorgverleners is een voorwaarde om transmurale zorg te realiseren maar is niet genoeg. Om duurzame transmurale zorg te kunnen bieden is samenwerking op een hoger niveau noodzakelijk: een zorgketen. 


\section{Diabetes Mellitus type 2}

Diabetes mellitus type 2 is een frequent voorkomende chronische ziekte leidende tot een aanzienlijke ziektelast en voortijdig overlijden. Diabetes mellitus is als een belangrijke cardiovasculaire risicofactor te beschouwen.

Niet alleen in de directe zorg maar ook aan de basis van de zorg bij het opstellen van richtlijnen, protocollen en standaarden bestaat de noodzaak tot samenwerking. De eerste standaard van het Nederlands Huisartsen Genootschap (NHG), gepubliceerd in 1989 en handelend over diabetes mellitus type 2 was opgesteld voor huisartsen door huisartsen, al werden wel enkele consulenten geraadpleegd. In 1999 verscheen de herziene standaard diabetes mellitus type 2 l van het Nederlands Huisarts Genootschap. Tot de auteurs behoorden nu, naast de vier expert huisartsen, twee expert internisten. Een daadwerkelijk voorbeeld van echelon doorbrekende transmurale samenwerking 'shared care'. (9)

Bij het toenemend aantal patiënten met diabetes mellitus type 2 vormen een transmurale standaard van goede kwaliteit, een multidisciplinair team waarin de diabetesverpleegkundige de spil vormt en specifieke aandacht voor de zelfzorg evenals voor goede transmurale afspraken, de basis van goede zorg. (10) In het boekje waaruit de voorgaande alinea een citaat is, worden zeventig transmurale diabetesprojecten besproken en inmiddels zijn daar nog projecten bijgekomen.(11) Het wijst op enthousiasme bij huisartsen, internisten, endocrinologen, diabetesverpleegkundigen, coördinatoren, diëtisten, podologen, en oogartsen. Het wijst ook op een gebrekkige overdracht aan de reguliere zorg van initiatieven die zijn ontplooid en geëvalueerd in projecten. Eigenlijk zou elke diabeet in Nederland erop moeten kunnen rekenen dat hij of zij transmurale zorg van goede kwaliteit krijgt, onafhankelijk van de vraag of er een a antal enthousiaste actievelingen een project hebben bedacht, gefinancierd gekregen in zijn of haar regio en uitgevoerd. 


\section{Transmurale zorg in Zwolle: ZODIAC}

(Zwolle Outpatient Diabetes Mellitus project Integrating Available Care) In Zwolle bestaat reeds gedurende meer dan tien jaar het KLIKinitiatief, waarbij er tussen eerste en tweede lijn wordt overlegd aangaande werkafspraken. Enkele jaren geleden is KLIK omgezet in het Medisch Coördinerend Centrum-KLIIK (MMC KLIK), dat zich tot doel stelt om de motor te zijn van de zorginnovatie bij de samenwerking tussen eerste en de tweede lijn. $\mathrm{Na}$ een eerdere succesvolle samenwerking tussen Dr. H.J.G.Bilo, internist in de Isala klinieken, locatie Weezenlanden en B.Meyboom-de Jong, hoogleraar huisartsgeneeskunde te Groningen, die resulteerde in het proefschrift van Goddijn, werd door Bilo en Meyboom met het MCC KLIK een nieuw plan ontwikkeld om de zorg voor diabetes daadwerkelijk in de eerstelijn door de huisarts te laten plaatsvinden met een dusdanige ondersteuning dat dit binnen enkele jaren zou kunnen leiden tot een verbetering van de kwaliteit van zorg. (12) Het Zwolle Outpatient Diabetes project Integrating Available Care (ZODIAC). In dit project konden huisartsen kiezen voor een van de volgende twee vormen van samenwerking: zorgvorm A waarin 32 huisartsen de driemaandelijkse controles voor hun patiënten met diabetes type 2 zelf uitvoeren en de jaarlijkse 'grote' controle wordt uitgevoerd door een diabetesverpleegkundige in dienst van het ziekenhuis; zorgvorm B, waarin 24 huisartsen zelf alle zorg verlenen, alle controles en verwijzingen uitvoeren en zo nodig 'on demand' een consult bij de diabetesverpleegkundige kunnen aanvragen bijvoorbeeld voor een voorlichtingsgesprek of het overschakelen op insuline; gegevens van deze twee zorgvormen werden vergeleken met die van een controle groep van 8 huisartsen (zorgvorm C) die de gebruikelijke zorg zelf leveren. Inmiddels heeft het project drie jaar van 1998 tot 2000 gefunctioneerd met succesvolle resultaten die elders worden gepubliceerd. Toen het project ten einde liep bleek het buitengewoon moeilijk om de succesvolle resultaten in de reguliere zorg te implementeren. Dat zat vast op financiën en menskracht, organisatie en regelgeving. Voor dit project dat een duidelijke kwaliteitsverbetering betekend is extra geld en menskracht nodig 
voor de aanstelling, scholing en honorering van de diabetesverpleegkundigen, voor de coördinatie van het project, voor de internisten die de berichten van de diabetesverpleegkundigen aan de huisartsen van een medisch oordeel voorzien, voor de huisartsen die dankzij de spiegelinformatie van het project meer tijd aan hun diabeten besteden, voor de oogartsen die de retina-foto's beoordelen. Alleen dank zij de inspanningen van alle betrokkenen en de steun van het MCC-KLIK en de specialisten, huisartsen en diabetesverpleegkundigen onder leiding van een deskundig coördinator zijn de jaren van ongewisheid, vooralsnog succesvol afgesloten met een verlenging van het project en zicht op implementatie in de reguliere zorg in de gehele regio op termijn.

Criteria voor succesrijke transmurale samenwerking zijn: goede samenwerking op de werkvloer - internisten, huisartsen en diabetesverpleegkundigen - een organisatie die de taal van deze beroepsbeoefenaren op de werkvloer spreekt en is vrijgesteld om het project te coördineren; een samenwerkingsorganisatie zoals MCCKLIK waarin de organisatie/ instellingen van de beroepsbeoefenaren vertegenwoordigd zijn: ziekenhuis, DHV, zorgverzekeraar. Tenslotte jarenlange informatie en onderhandeling met de zorgverzekeraar, die weliswaar gebonden is aan nationale wetten regelgeving, maar toch keuzen moet leren maken in een medische wereld vol (gewenste) veranderingen.

Tenslotte kan een project alleen als waardevol of succesvol worden beschouwd als het geëvalueerd en gepubliceerd is, zodat ook samenwerking met een wetenschappelijk instituut, zoals een universiteit, noodzakelijk is.

\section{Edisse studie}

Bij de zorg voor CVA-patiënten - jaarlijks 27000 nieuwe in Nederland zijn vele hulpverleners van verschillende disciplines betrokken met als. gevolg onvoldoende coördinatie en afstemming. In de Edisse studie zijn drie regio's waar een zorgexperiment met 'stroke-service' werden uitgevoerd, vergeleken met drie regio's waarin gebruikelijke zorg werd verleend.(3) 
In de projecten van de Edisse studie is de huisarts niet betrokken, ook niet in de drie studies van de experimentele regio's waar voorbeeldige zorg in strokeservices geleverd zou worden. Er wordt in verschillende schema's gesproken van de thuiszorg voor CVA-patiënten van wie $60 \%$ na kortere of langere tijd naar huis terugkeert. De huisarts maakt echter geen deel uit van de thuiszorg. De huisarts zou bij deze studies apart betrokken moeten worden. De meeste onvoldoendes in de experimentele en controle regio's betreffen na-en thuiszorg. In het rapport is een aparte paragraaf gewijd aan het ontbreken van het betrekken van de huisarts. Er is in dit project dus geen sprake van een stroke service maar van een intramurale stroke unit plus gebrekkige voor- en nazorg.

\section{Tot slot}

In het kader van de academisering van de huisartsgeneeskunde die vrijwel overal in Nederland in volle gang is, trachten in Noord Nederland het Academisch Ziekenhuis Groningen, de Faculteit der Medische Wetenschappen en de disciplinegroep Huisartsgeneeskunde een academische zorgketen te realiseren. Hierbij speelt een grote universitailre huilsartspraktijk te vestigen op het terrein wan het ziekenhuis, waar tien huisartsen zorg gaan verlenen aan ca.15.000 ingeschreven patiënten naast onderwijs en onderzoek, een belangrijke rol. Het gaat om een zorgexperiment dat expliciet geëvalueerd wordt en waarvan de succesvolle elementen in de reguliere zorg worden geïmplementeerd Dit is samenwerking op niveau 5 uit het juist beschreven model na te streven. Het plan is topdown ontwikkeld. De fasen 1, 2, 3 en 4 moeten nog doorlopen worden. Samenwerking op de werkvloer tussen huisartsen en specialisten zal nog opgebouwd worden. Gelukkig is er veel belangstelling.

\section{Literatuur}

1. Crebolder HFJM. Onderzoekingen rond een gezondheidscentrum. Clienten,clifers, beschouwingen [dissertatie] Nijmegen: Katholieke Universiteit Nijmegen, 1977. 
2. Ubink-Veltmaat $\sqcup$, Risschen RO, Meyboom-de Jong B, Bilo HJG. Structural support significantly improves cardiovascular riskfactors in type 2 diabetes in daily practice. Diabetologica 2000, 43 (suppl1): A236 (Abstract)

3. Huijsman R, Klazinga NS, Scholte op Reimer WJM et al. Beroerte, beroering en borging in de keten. Resultaten van de Edisse-studie van drie regionale experimenten met stroke service Edisse (Evaluation Dutch Integrated Stroke Service Experiments). ZON/MW et al, 2001

4. Berendsen A, Schuling $\mathrm{J}$, Meyboom-de Jong B. Ziekenhuisverplaatste zorg een literatuurstudie (submitted).

5. Spreeuwenberg C, Elfahmi DMM.Transmurale zorg: redesign van het zorgproces, Achtergrondstudie. Zoetermeer, 1999

6. Nationale Raad voor de Volksgezondheid. Transmurale somatische zorg. Advies van de NRV en het College Ziekenhuiswoorzieningen. Zoetermeer/Utrecht, 1995.

7. Raad voor de Volksgezondheid en Zorg. Redesign van de eerste lijn in transmuraal perspectief. Zoetermeer, 1999

8. Bokken BWTM. De samenwerking tussen huisarts en specialist, een model. Huisarts \& Wet, 1995; 38: 506-12.

9. Rutten GEHM, Verhoeven S, Heine RJ, et al. NHG-standaard diabetes mellitus type 2. Huisarts \& Wet 1999; 42:67-84

10. Meyboom-de Jong $B$. Transmurale zorgvormen van diabetes mellitus: kloof tussen theorie en praktijk na vijf jaar opnieuw bekeken. In Bilo HJG, Nunen F van, ed. Transmurale zorgvormen van diabetes mellitus. Zwolle: Isala klinieken, 2000

11. Wolffenbuttel BHR, Nunen F van, Bilo HJG, Weel $C$ van.

Transmurale diabeteszorg. The dawning of a new era. Zutphen, Walburg Druk, 2002

12. Goddijn PPM. Improving metabolic control in NIDDM patients referred for insulin therapy. [dissertatie] Groningen:

Rijkuniversiteit Groningen, $1997^{\circ}$

Mevr. Prof. dr. B. Meyboom-de Jong is hoogleraar Huisartsgeneeskunde aan de Rijksuniversiteit Groningen. 


\section{Harry Crebolder}

pleitbezorger van de generalistische geneeskunde; niet alleen van de huisartsgeneeskunde, maar ook een beetje van de geneeskunde voor verstandelijk gehandicapten en van de verpleeghuisgeneeskunde.......

Ferd Sturmans en Jos Schols.

\section{Inleiding}

Mijn (FS) eerste kennismaking met $\mathrm{HC}$ was in Nijmegen, op vrijdag 30 september 1977, als opponent bij de verdediging van zijn proefschrift "Onderzoekingen rond een gezondheidscentrum: cliënten, cijfers, beschouwingen" met als promotor Professor Huijgen, Harry's voorbeeld als pleitbezorger van de generalistische geneeskunde. HC was toen al sedert 1 mei 1972 werkzaam in het gezondheidscentrum Het Withuis in Venlo. Gezondheidscentra waren in die tijd geen vanzelfsprekende zaak. Er moest voor gevochten worden.

En dat heeft HC gedaan. Vanuit Nijmegen lag Venlo halverwege Maastricht. Daar kwamen wij elkaar weer tegen. Maastricht had net een bijzondere opdracht richting eerstelijns onderwijs en onderzoek gekregen.

Het was dan ook niet verwonderlijk dat Co Greep, op dat moment decaan in Maastricht, het Withuis had gekozen als een van zijn speerpunten in het proces van academisering van de eerstelijn. Het Withuis moest de grens gaan vormen in het Noorden richting Nijmegen en dus moest het Withuis geacademiseerd worden. Inmiddels had ik (FS) de functie van decaan van Co Greep overgenomen en mocht $i k$ de onderhandelingen met het Withuis afronden. Niet lang daarna werd $\mathrm{HC}$ benoemd tot eerstelijns onderwijscoördinator en mocht hij mede leiding geven aan de onderhandelingen met andere huisartspraktijken. Dat heeft hij steeds met veel verve gedaan en dat doet hij nog. Bij de taakverdeling tussen de hoogleraren is dit bovendien nog steeds zijn aandachtsgebied.

Het eerstelijns onderwijscoördinatorschap was evenwel een te beperkte opdracht voor $\mathrm{HC}$ met zijn behoefte aan onderzoek. 
Tegen die achtergrond heb ik samen met $H C$ enkele promovendi mogen begeleiden en daarbij bleek dat de interesse van Harry niet beperkt was tot die van de huisartsgeneeskunde in engere zin. $\mathrm{HC}$ bleek ook zo zijn opvattingen te hebben over de academisering van de zorg voor verstandelijk gehandicapten en de verpleeghuisgeneeskunde.

Toen Jos Schols, mijn medeauteur, verpleeghuisarts en directeur van de Riethorst in Geertruidenberg, ontdekt had dat ik ook in Geertruidenberg woonde en hij te kennen gaf gaarne te willen promoveren, heb ik dan ook meteen contact gezocht met HC. Samen hebben wij Harry en Emma nog beter leren kennen.

Wij hebben Harry leren kennen als iemand die altijd een huisarts in hart en nieren, een gemotiveerd opleider en ook een ged reven onderzoeker is geweest!

Hij heeft het uitdragen en onderbouwen van zijn vakgebied steeds als leidraad voor zijn werkzaamheden beschouwd.

Als huisarts, opleider en onderzoeker heeft hij daarmee een niet geringe bijdrage geleverd aan de fundering en de professionalisering van het vakgebied van de huisartsgeneeskunde.

\section{Samenwerking noodzakelijk}

Harry is zelf ook altijd geboeid geweest door het streven naar samenhang en samenwerking binnen de gezondheidszorg; een streven dat in het actuele transmurale tijdperk steeds' essentiëler is geworden! Het realiseren van optimale continuiteit van zorg was en is daarbij het uitgangspunt.

In het verlengde hiervan is hij onder meer nauw betrokken geweest bij onderzoek betreffende de samenwerking tussen huisarts en medisch specialist en ook bij onderzoek betreffende de samenwerking tussen huisarts en verpleeghuisarts (JS). Uit deze onderzoeken zijn reële aanwijzingen naar voren gekomen dat een goede onderlinge samenwerking ten goede komt aan de continuiteit en kwaliteit van de zorg.

$\mathrm{HC}$ was er zich dus goed van bewust dat de huisdokter het niet altijd alleen af kan. 
In dit kader zullen wij nader ingaan op enerzijds de samenwerking met de openbare gezondheidszorg en anderzijds op de samenwerking met de verpleeghuisarts, in de zorg voor ouderen.

\section{Samenwerking met de openbare gezondheidszorg (FS)}

De vraag naar gezondheidszorg zal in dit millennium steeds groter worden. Een duidelijke voorbode daarvan is de nu al steeds maar toenemende werkdruk van huisartsen.

Willen we de problemen die op ons afkomen kunnen tackelen, dan is het noodzakelijk dat er meer intersectorale samenwerking komt tussen de openbare en curatieve gezondheidszorg en tussen de gezondheidszorg en andere sectoren. Dit enerzijds orn collectieve preventie mogelijk te maken en anderzijds de vraag naar zorg te verminderen.

Een aantal ontwikkelingen binnen de samenleving verhoogt de druk op de gezondheidszorg. In de eerste plaats nemen de sociaaleconomische gezondheildsverschillen weer toe. Over de hele linie is de volksgezondheid verbeterd, maar de hoog opgeleiden hebben daar veel meer van geprofiteerd dan de lager opgeleiden. Bovendien is er bij mensen met een lage sociaal-economische status sprake van een ophoping van problemen. Een lage opleiding gaat vaak samen met werkloosheid, slechte huisvesting en ongezonde leefgewoonten. Hoe langer mensen leven in stressvolle economische en sociale omstandigheden, des te kleiner de kans op een gezonde oude dag, als gevolg van een grotere fysiologische slijtage.

Een andere ontwikkeling die de druk op de gezondheidszorg verhoogt, is de groei van de diverse groepen allochtonen binnen onze samenleving. Het wordt steeds duidelijker dat ook bij hen sprake is van een accumulatie van gezondheidsproblemen, met als gevolg een te verwachten toenemende druk op de gezondheidszorg.

Een derde belangrijke ontwikkeling binnen onze samenleving, die de druk op de gezondheidszorg verder vergroot, is de vergrijzing. Ouderen kampen vooral met chronische gezondheidsproblemen. Ondanks een langer leven slijten zij de laatste 10 tot 15 jaar van hun leven over het algemeen in een mindere gezondheid. 
Kortom de huisarts ziet zich geconfronteerd met een steed's grotere zorgvraag.

De vraag is in welke richting we een oplossing moeten zoeken.

Een aantal suggesties (FS).

Voorop staat dat er meer aandacht voor preventie nodig is!

De overheid besteedt nu $40 \%$ van haar zorgbudget aan curatieve en somatische zorg. Slechts $2 \%$ hiervan is bestemd voor preventie; een wel erg schril contrast. Preventie zou een veel sterkere rol moeten krijgen binnen de eerstelijn. Daartoe zou onder meer de samenwerking tussen huisarts en openbare gezondheidszorg verbeterd moeten worden.

Zo maar een paar voorbeelden.

Voor migranten beschikken de GGD's over speciale migrantenvoorlichters die ook ingezet kunnen worden om de vaak gebrekkige communicatie tussen huisarts en allochtone patiënt te verbeteren. Deze migrantenvoorlichters kunnen tijdvretende communicatieproblemen helpen voorkomen, culturele verschillen overbruggen, helpen bij het opstellen van een behandelplan en de allochtone patiënt begeleiden in ons systeem van gezondheidszorg. Huisartsen kunnen er hun voordeel mee doen en de hulpverlening zelf kan erdoor verbeteren.

Huisartsen zouden ook meer nadrukkelijk betrokken moeten worden bij de lokale zorgnetwerken, waardoor ze er beter terecht kunnen bij confrontatie met complexe problemen in hun praktijk.

Juist het samenwerken met vertegenwoordigers van andere sectoren biedt goede mogelijkheden om gezondheidsproblemen preventief te lijf te gaan.

De openbare gezondheidszorg heeft veel ervaring op het gebied van intersectoraal samenwerken en bovendien de kennis op het gebied van sociale determinanten van gezondheid en ziekte. Ze kan deze kennis prima delen met de huisarts en met anderen binnen en buiten de gezondheidszorg. 


\section{Verpleeghuisgeneeskunde (JS)}

Het is belangrijk om te vermelden dat Harry zich in zijn activiteiten, als oud tropenarts en nadien als huisarts en huisartsonderzoeker, altijd verbonden heeft gevoeld met het lot van de zeer kwetsbare patiënt!

Hij zag als geen ander in dat de generalistische medische zorg voor specifieke doelgroepen patiënten, met chronische stoornissen, beperkingen en handicaps, vaak een echt specifiek karakter heeft. Naast de huisartsgeneeskunde als "generalistisch specialisme" heeft hij zich nadrukkelijk verdiept in de verpleeghuisgeneeskunde én in de geneeskunde voor patiënten met een verstandelijk handicap.

Het is dan ook niet verwonderlijk dat hij zich tot op het laatst heeft ingezet om ook in Maastricht tot academisering van de verpleeghuisgeneeskunde te komen. Hopelijk zullen zijn pogingen om een leerstoel verpleeghuisgeneeskunde aan de UM te realiseren op niet al te lange termijn concreet gestalte krijgen.

Het zal duidelijk zijn dat ik (JS) hier graag nog even op door wil gaan. Indien de verpleeghuisgeneeskunde in Maastricht een plaats aan de universiteit zal krijgen, zal dit een aantal interessante perspectieven bieden.

Ten eerste kan het onderwijs aan medisch studenten er zowel op het theoretische als praktische vlak, gedurende het hele curriculum, een extra impuls door krijgen. Met het oog op de doelgroepen ouderen en chronisch zieken betreft dit vooral de verdieping op het medische en zorginhoudelijke vlak én op het gebied van de begeleiding. Deze patiënten hebben meestal allerlei stoornissen, beperkingen en handicaps, waardoor het accent in de hulpverlening vaak meer op care en palliatie ligt dan op cure.

Op onderzoeksgebied biedt de universitaire aanwezigheid van de verpleeghuisgeneeskunde nieuwe kansen om kwalitatief verantwoorde beloopstudies te verrichten met betrekking tot de ziekte- en zorgcarrière van patiënten met chronische aandoeningen, die uiteindelijk in het verpleeghuis moeten worden opgenomen. Dergelijk onderzoek kan bovendien prima ter hand genomen worden samen met andere vakgroepen. 
Ook het reeds in gang gezette transmurale onderzoek kan verder uitgebreid worden tot het hele zorgcontinuüm, omdat vanuit verpleeghuizen inmiddels tal van transmurale initiatieven ontwikkeld zijn, zowel richting ziekenhuis als eerstelijn.

Lat but not least biedt een en ander voor de UM ook perspectieven om de banden met de verpleeghuizen in de omgeving aan te halen. Rondom de universiteit zou een universitair netwerk van verpleeghuizen opgericht kunnen worden, waarmee ook in de chronische zorgsector academische werkplaatsen ingericht kunnen worden.

\section{Epiloog}

Wij zijn ervan overtuigd dat Harry een sterk aanhanger van deze ideeën is.

Met recht mag hij immers een pleitbezorger en voortrekker van de generalistische geneeskunde genoemd worden.

Niet op de laatste plaats is het tenslotte belangrijk om te memoreren dat hij, binnen en buiten de universiteit in de diverse rollen die hij moest vervullen, steeds een betrouwbare collega, leider en vriend is geweest.

Voor promovendi was hij een strenge, principiële doch rechtvaardige leermeester ên ook een coach, op wiens steun je altijd kon rekenen. En last but not least...; thuis, met zijn Emma, heeft de deur altijd opengestaan voor hen die met hem mochten samenwerken.

In de toekomst zal die deur ongetwijfeld voor velen open blijven staan! voor dit alles passen dan ook oprechte woorden van respect en dankbaarheid!

Harry en ook Emma, het ga jullie goed!

Prof. dr. F.Sturmans was eertijds hoogleraar epidemiologie en decaan van de Faculteit der Geneeskunde van de UM en is thans directeur van de GGD te Rotterdam.

Dr. J.M.G.A. Schols is directeur van het verpleegtehuis

St. Geertruidenberg. 


\section{E en bevlogen dokter}

\section{Cor Spreeuwenberg.}

Harry Crebolder heb ik voor het eerst ontmoet in 1981. Het kenmerkt Harry dat ik nog steeds weet waar en wanneer dit het geval was: op 24 november 1981 om ongeveer 21.00 uur, toen we achter elkaar in de iij stonden tijdens het diner op het lustrumcongres van het 25-jarige NHC in het Congresgebouw te Den Haag. Harry had eerder dat jaar in Huisarts en Wetenschap bijzonder aardige dingen over mijn proefschrift geschreven. Onmiddellijk wist ik dat ik met een ongewone man van doen had: het gesprek ging direct over wezenlijke zaken en ik merkte dat ik met een charmante en tevens zeer bevlogen huisdokter van doen had.

Natuurlijk kende ik de naam van Harry al van zijn reeks onderzoeksartikelen, halverwege de jaren zeventig in Huisarts en Wetenschap over het Withuis in Venlo. Bijzonder aan dat promotieonderzoek was dat hij - een kwart eeuw voor de termen vraaggericht en vraaggestuurd in het beleidsjargon te pas te onpas werden gebruikt - al onderzoek deed naar de verwachtingen en ervaringen van patiënten, voorall ten aanzien van de introductie van het multidisciplinaire team in de huisartspraktijk. Was de wijze waarop destijds binnen de eerste lijn over samenwerking werd gesproken nogal esoterisch van aard, Harry maakte een dergelijke samenwerking concreet door het over doel, methoden en uitkomsten te hebben, bijvoorbeeld waar het gaat over zorg aan patiënten en familieleden in verband met sterven.

Het Withuis behoorde indertijd tot een spraakmakende groep gezondheidscentra zoals Ommoord te Rotterdam, Hoensbroek-Noord te Hoensbroek en Heimerstraat te Amsterdam, die, met de zogeheten pseudo-groepspraktijk te Nijmegen, in de jaren zeventig probeerden de huisartsgeneeskunde tot volwassenheid te brengen door patiëntenzorg te combineren met onderwijs en onderzoek. De huisartsen in deze settings waren vernieuwers van de eerste orde. Zij wilden bewijzen dat huisartsgeneeskunde als discipline voor continue, integrale en persoonlijke medische zorg aan mensen en hun familieleden niet zo maar een kreet was van de het jonge NHG maar dat de visie die daarachter zat tot effectieve en kwalitatieve 
verantwoorde zorgverlening kan leiden. Deze huisartsen barstten als het ware van zelfbewustzijn en droegen met verve dle overtuiging uit dat mensen voor verreweg het grootste gedeelte van hun aandoeningen niet aangewezen behoefden te zijn op medische specialisten in het ziekenhuis. Zij konden dit laatste ook omdat de meeste huisartsen uit deze centra uitnemende dokters waren die hun vak goed beheersten en zich niet met de hand aan de pet bij de specialist hoefden te voegen maar in staat waren deze kritisch te bevragen over het hoe en waarom van zijn handelen. Dat Harry tot de laatste groep hoorde bleek mij later wel eens als zijn naam toevallig ter sprake kwam in een gesprek met een specialist uit Venlo. Ze vonden hem niet enkel lastig maar leken zelfs bang voor hem te zijn. Die angst kwam mogelijk voort omdat Harry een man met een visie en van principes is. Zijn visie op de eerste lijn heeft Harry ontleend aan zijn ervaringen, begin jaren zeventig, in Tanzania waar een groot en prestigieus ziekenhuis was neergezet dat echter razend duur was en slecht functioneerde. Als het geld was besteed aan goede primary health care zouden veel meer mensen daarvan profijt kunnen hebben. Als Harry over die jaren daar vertelde was het verdriet en de boosheid over het onbenut laten van de mogelijkheden om de Tanzaniaanse bevolking goede zorg te geven voelbaar. Voor Harry gold dat echter niet alleen voor Tanzania, ook in Nederland zou de overheid verstandiger met het budget voor volksgezondheid kunnen omgaan, als ze de moed zou hebben geld te re-alloceren van tweede naar eerste lijn.

Onze ontmoeting in Den Haag uit 1981 deed ons naar meer verlangen. Om elkaar beter te leren kennen, zochten we elkaar thuis op. Toen het er in 1984 naar uitzag dat de Vrije Universiteit de gelegenheid zou krijgen een vernieuwde afdeling huisartsgeneeskunde op te bouwen, leek Harry de geschikte persoon om daaraan mede leiding te geven. Echter, het offer zou voor Harry en Emma aanzienlijk zijn, terwijl het perspectief nogal ongewis was. Tweemaal is Harry toen in Amsterdam geweest: eenmaal gefẽteerd door de toenmalige decaan en eenmaal aan een kruiswerhoor onderworpen door de vakgroep. Dit laatste veroorzaakte een dermate onrustig buikgevoel dat Harry 
besloot in Venlo te blijven en betere tijden en vooruitzichten af te wachten. Vanuit zijn standpunt was dat begrijpelijk. Het karakteriseert Harry ten voete uit dat hij zich niet liet verleiden door de eer van een hoogleraarschap, maar dat hij zijn gevoel een centrale plaats gaf in zijn beslissing. Zijn beslissing had echter ook een andere kant: voor mij was het jammer omdat daarmee het momentum om iets te bereiken en door te drukken voorbij zou gaan. Even later werd het faculteitsbestuur, vanwege zijn visie op de noodzaak van huisartsgeneeskunde iets te maken, vervangen door een bestuur met geheel andere opvattingen.

Dat ik graag met Harry in zee had willen gaan heeft te maken met zijn duidelijke visie op de eerste lijn en met de wijze waarop hij vindt dat gestalte moet worden gegeven aan het dokter-zijn. Hoewel Harry niet overtuigd hoefde te worden van de noodzaak oog te hebben voor psychosociale en contextuele aspecten van ziek-zijn en ziek-voelen, was hij geenszins een 'softe' dokter. Heerste er begin jaren tachtig onder sommige huisartsen de opvatting dat individuele zorgverlening en gedegen kennis van diagnostiek en behandeling voor een huisarts niet zo van belang was, Harry had daarover stellige, afwijkende opvattingen. Harry zag de huisarts inderdaad als een 'omnipracticien' maar niet als een blotevoeten of geitenwollen sokken dokter. Een huisarts was in zijn ogen iemand die deskundig moet zijn op een breed gebied van afwijkingen. De opleiding moest erop worden gericht huisartsen voor deze zware taak toe te rusten.

Harry werd benoemd tot hoogleraar ter coördinatie van het onderwijs in de eerstelijns gezondheidszorg aan destijds nog de Rijksuniversiteit Limburg. Co Greep heeft een belangrijke rol gespeeld in zijn komst naar Maastricht. Bijzonder was dat twee hoogleraren specifiek met het klinische onderwijs werden belast: Gerard Essed die zich ging bezighouden met het onderwijs intramuraal en Harry die het onderwijs extramuraal zou gaan stimuleren. Harry wilde graag alle studenten kennis laten maken met de gezinsgeneeskunde, het - volgens zijn leermeester Frans Huygen - centrale paradigma van de huisartsgeneeskunde. Hij zocht voor dit praktische medische 
onderwijs contact met mijn VU-collega in de kindergeneeskunde Guus de Jonge die voor jongere jaars medische studenten een stage had georganiseerd waardoor ze de ontwikkeling van jonge kinderen in het gezin van hun ouders konden volgen.

Hoewel Harry een hoogleraar eerstelijnszorg "pur sang" is, gaf hij in zijn oratie aan dat - als het er op aan zou komen - het hem niet om het slechten van de muren tussen de intra- en extramurale zorg ging en dat de basisfilosofie voor hem evenmin het hoogste goed was. Aan de wijze waarop hij zijn leeropdracht wilde invullen lag uiteindelijk de overtuiging ten grondslag dat de patiënt een betere, volwaardiger arts mag verwachten die tegelijk rationeel werkt, zorg heeft en zorg geeft.

Al snell werd de opdracht van Harry omgezet van onderwijs in de eerstelijns gezondheidszorg naar het vakgebied huisartsgeneeskunde. Hierdoor kreeg hij de ruimte zijn werkveld te verbreden van het studentenonderwijs naar het verbeteren van de beroepspraktijk van de huisarts. Op verschillende wijzen heeft Harry - hierbij gesteund door zijn kompaan George Beusmans - geprobeerd aan dit laatste gestalte geven. Craat het de universiteit veelal om onderwijs en onderzoek alleen, Harry heeft zijn opdracht altijd verstaan als het bijdragen aan de ontwikkeling en de verbetering van de beroepspraktijk. Op verschillende wijzen heb ik met deze 'drive' van Harry te maken gehad. Als hoofdredacteur van Medisch Contact kreeg ik de artikelen ter beoordeling waarin Harry en George betoogden dat grootschalige samenwerking en HOED-constructies een absolute voorwaarde zijn om de kwaliteit van de huisartsenzorg te verzekeren. Rationeel kunnen werken betekent dat de huisarts zijn werk moet baseren op resultaten van onderzoek over de beroepspraktijk. Tegen de opvattingen in van zijn collegae hoogleraren huisartsgeneeskunde heeft Harry eigenzinnig gebruik gemaakt van het initiatief van de Adviesgroep Stimulering Gezondheidsonderzoek (SGO) om een kaderopleiding huisartsgeneeskunde te initiëren waardoor jonge huisartsen niet alleen konden worden geschoold in het verrichten van wetenschappelijk onderzoek maar daarbij ook buitenlandse ervaring moesten opdoen. Met Jos Op 't Root als coördinator werd een 
structuur ontworpen waardoor vanuit Maastricht zo'n tien huisartsen de bijzondere evaring van zo'n opleiding tot lid van een keurkorps konden opdoen. Hoewel enorme praktische problemen moesten worden overwonnen, plukken verschillende universiteiten op dit moment de vruchten van de gelegenheid waarvan Harry behendig en volhardend gebruik heeft gemaakt.

Standvastigheid is een wezenskenmerk van Harry. Dat heb ik gemerkt toen ik als voorzitter van de subcommissie geneeskunde van de visitatiecommissie van de VNSU in 1991 met Harry te maken kreeg omdat hij wilde protesteren tegen het voornemen van de faculteit naar ik veronderstel vanwege financiële motieven - om het coassistentschap huisartsgeneeskunde niet uit te breiden maar te bekorten. Harry had er toen grote mee dat het schema en de structuur van de visitatie weinig ruimte bood voor het aanhoren van protesten en dat ik de opvatting had dat ik me als voorzitter op de faculteit als geheel en niet als belangenbehartiger van een deel, de huisartsgeneeskunde, moest opstellen. Ik denk trouwens dat Harry er wel eens moeite mee heeft gehad dat ik - hoewel toen zelf nog praktizerend als huisarts - de huisartsgeneeskunde enigszins begon te relativeren nadat ik benoemd was tot hoofdredacteur van Medisch Contact. De levensloop van Harry laat zien dat hij zijn missie duidelijk ziet in het versterken - waar mogelijk - van de eerste lijn. Ik denk dat hij belangstelling heeft voor transmurale samenwerking omdat samenwerking met medisch specialisten kansen biedt om huisarts in hun werk te ondersteunen. Ik verschil in die zin iets van Harry dat ik een ander vertrekpunt voor mijn carrière heb gehad, omdat ik aanvankelijk geen huisarts maar internist wilde worden. De gebrekkige kwaliteit van de opleiding tot internist indertijd en het in het ziekenhuis ontstane gevoel dat veel patiënten door een goede huisarts 'beter' geholpen kunnen worden, hebben mij naar de huisartsgeneeskunde gedreven. Hoewel ik ervan overtuigd ben in hart en nieren als huisarts te hebben gefunctioneerd, heb ik nooit de gedachte gehad mij tegen de specialistische geneeskunde af te zetten. In de tweede helft van de jaren tachtig begon ik vraagtekens te zetten bij de opvatting dat alle huisartsen geacht worden in staat 
te zijn een heel breed scala van afwijkingen verantwoord zelf te behandelen. Daarvoor zag ik te grote kwaliteitsverschillen om mij heen, verschillen die ik ook goed kon begrijpen vanuit verschillende ambities, interesses en situaties waarin het beroep moet worden uitgeoefend. I $\mathrm{k}$ vond het daarom niet zo erg als mijn collega iemand verwees in gevallen waarin ik de patiënt zelf behandelde.

Vanaf 1994 kreeg ik meer met Harry te maken nadat ik was benoemd om in Maastricht gestalte te geven aan nieuwe vormen van geïntegreerde zorgverlening aan chronisch zieken. Ik begrijp heel goed dat Harry graag had gezien dat ik mijn energie zou hebben aangewend om het huisartsen en het onder hun leiding werkend personeel mogelijk te maken veel voorkomende aandoeningen zelf te behandelen. Ik heb hiervóór echter al aangegeven waarom ik wel geloof dat een aantal individuele huisartsen mensen met diabetes mellitus, astma, COPD, hartfalen of depressie kwalitatief verantwoorde zorg zal en kan geven, maar dat ik het te riskant vind om er vanuit te gaan dat alle huisartsen dat zullen doen. Daarom heb ik er bewust voor gekozen - ook omdat ik wel wist dat Harry en George zich toch wel zouden blijven richten op het verder ondersteunen van huisartsen - mij te richten op het ontwikkelen van een alternatieve model: het delegeren van de zorg - inclusief de medische zorg - aan gespecialiseerde verpleegkundigen.

Natuurlijk is het wel eens lastig geweest dat wij soms uiteenlopende wegen hebben bewandeld, maar dankzij de óvertuiging van ons beiden dat het uiteindelijk gaat om goede zorg aan de mens die lijdt, hebben we elkaar ook weer kunnen vinden in het Quatro-model waarin we onze twee benaderingen hebben verenigd. In dit model staat kwalitatieve zorgverlening aan specifieke groepen chronische patiënten voorop; het model kent tevens een systeem van kwaliteits bewaking. Erbinnen is zowel plaats voor de huisarts die met zijn of haar praktijkondersteuner zelf de chronische patiënt wil behandelen als voor de huisarts die een deel van de patiënten wil laten behandelen door de gespecialiseerde verpleegkundige. Dit model honoreert de specifieke deskundigheden van zowel specialist als generalist als van de arts en de verpleegkundige. 
De eerste maal zag ik Harry in de rij in Den Haag. Daarna zijn we in uiteenlopende situaties en op verschillende plaatsen op deze aardbol met elkaar opgetrokken. Als wij verschillende inzichten hadden betrof dit nooit doelstellingen of principes maar altijd de weg om iets te bereiken. Dergelijke niet insnijdende verschillen maken het spannend en interessant om met iemand te verkeren. Hoe zou het anders kunnen met een aardige, bevlogen dokter van een kaliber als Harry?

Prof. dr.C. Spreeuwenberg is decaan van de Faculteit Gezondheidswetenschappen van de UM. 


\section{"OId soldiers never die, some of them will not even fade away" \\ Omzien en vooruitkijken bij het emeritaat van Harry Crebolder}

Geertjan Wesseling.

Het vertrek van een vooraanstaand lid van de universitaire gemeenschap is altijd een mooi moment om even bij stil te staan. zeker als het iemand als Harry Crebolder betreft. Het brengt je tot nadenken over loopbaan en carrière in algemene zin en de loopbaan van de vertrekker (en je eigen loopbaan) meer in het bijzonder. Van de loopbaan van Harry heb ik overigens alleen het ( $k$ wispelende) staartje meegemaakt, maar stof tot nadenken geeft dat voldoende.

Er bestaan verschillende manieren waarop je je loopbaan kunt besluiten. Helaas is een enkeling noodgewongen door fysiek of ander ongemak genoodzaakt of gedwongen zijn of haar loopbaan te beëindigen.

Anderen hebben bijtijds de schaapjes op het droge en gaan in Spanje of een ander aangenaam oord golfen en rentenieren. Voor veel schaapherders, om ze zo maar te noemen gaat dat niet op want die hebben doorgaans de "drive" om nog meer schaapjes op het droge te krijgen. Je kunt ook rustig de rit uitzitten en al dan niet tevreden omziend op je vijfenzestigste, of zoveel eerder als de rit eindigt, de deur achter je dichttrekken. Je kunt ook na veertig dienstjaren met een fraai doublé horloge en een ruiker voor thuis afzwaaien. Echter, voor hen die eerst na een lange opleiding aan een actieve loopbaan beginnen, wat geldt voor de meesten van ons soort, is veertig dienstjaren meestal een utopie.

Je kunt ook voor de eindstreep afbranden en voortijdig de aftocht blazen of heen gezonden worden. Dat schijnt ook onder dokters voor te komen want de cijfers lijken erop te wijzen dat het aantal collegae dat via deze route achter de coulissen van het podium van de gezondheidszorg belandt de laatste jaren toeneemt. Sommigen worden na hun vertrek (doorgaans maar beperkte tijd) node gemist, in het geval van anderen tikt de klok juist wat te langzaam. 
In het geval van Harry Crebolder gaat dit alles niet op. Voor Harry is het jammer dat we hier het Amerikaanse systeem niet hebben. Een of twee stapjes terug maar nog een tijdje doorgaan met waar je goed in was, bent en blijft. Als je een Amerikaanse collega uitlegt dat het hier voor wat betreft je academische carrière met 65 met je gedaan is, dan kijken ze je meewarig aan en spreken schande van dat je zo makkelijk en resoluut afscheid neemt wan een schat aan ervaring, kennis, expertise en in veel gevallen vaak ook vitaliteit en activiteit.

Zo moet je het afscheid van jou, Harry ook beschouwen. Veel van de mensen in jouw beroepsmatige omgeving hebben het boek Crebolder nog niet uit. Jongere collega's stralen vaak nog niet het enthousiasme en het engagement uit voor onderwijs, onderzoek, zorgvernieuwing en wat dies' meer zij, dat jij ook nu bij je afscheid nog uitstraalt. Jouw trefwoord moge daarbij "clebat" zijn, maar het had net zo goed "betrokkenheid", "commitment", "verantwoordelijkheidsgevoel" of n'importe welke andere positieve karaktereigenschap mogen zijn. In die eigenschappen ben je voor veel van de mensen om je heen een voorbeeld geweest. Je niet aflatende ijver voor de zaak, binnen of buiten je vakgroep, de eerste lijn, de faculteit of vooral de laatste jaren het ziekenhuis heeft vellen van ons aangezet tot grotere inzet en enthousiasme.

Ik heb je de maanden voor je vertrek aandachtig geobserveerd. Af en toe leek het alsof je halast had. Alsof je alles voor je vertrek geregeld wilde hebben. Het had niet het karakter van "over je graf heen regeren", maar je gaf wel de indruk dat je nog lang niet klaar bent. Troost je met de gedachte dat veel van je gedachtegoed over de huisartsgeneeskunde en de relatie tussen de eerste en de tweede lijn, over het curricullum van het geneeskunde onderwijs en over al die andere zaken waarmee je je tijdens je carrière hebt bezig gehouden, inmiddels bij zoveel anderen heeft postgevat dat die treinen ook na je vertrek zullen blijven doorrijden. Trouwens, zo makkelijk zullen we heus niet van je af komen. Je zult het immers niet kunnen laten om je, op de verschillende manieren die je daarvoor zult weten te verzinnen, te blijven bemoelien met de zaken die je aan het hart gaan. Ik kan me niet voorstellen dat je belangstelling voor en 
betrokkenheid bij je eigen stokpaardjes opdroogt door iets triviaals als een emeritaat. "Als die ouwe maar niet in de weg gaat lopen", zal je opvolger wellicht denken. Die kunnen we nu alvast gerust stellen. Daar ben je waarschijnlijk te bescheiden voor. En dan nog, hij of zij kan er waarschijnlijk zijn of haar voordeel mee doen. Zoals gezegd, waarom zo'n schat aan ervaring en enthousiasme afschrijven als je er nog profijt van kunt hebben. Ik persoonlijk hoop je daarom ook na je vertrek nog regelmatig te mogen ontmoeten en raadplegen. Veel van je ideeën zullen niet snel maderiseren, om er maar eens een wijnterm voor te gebruiken en, om in diezelfde wijnterminologie te blijven, met het afbreken van de zuren en de tannines wint een mooie Bourgogne aan raffinement en complexiteit.

Harry, het ga jou en ons allemaal goed.

Dr. G.J. Wesseling, longarts, is Universitair Hoofddocent en voorzitter van de Taakgroep PMO studiejaren 5-6 aan de UM. 


\section{S tageoverstijgend klinisch onderwijs; integratie tussen lijnen en disciplines}

Gerard Essed.

In het oude Babylonie - meer dan vijftien eeuwen voordat Hippocrates en zijn tijdgenoten hun stempel drukten op de hedendaagse geneeskunde - bestonden er reeds in spijkerschrift vastgelegde regels waar medici aan moesten voldoen. [1] Ook waren er vastgestelde straffen bij (kunst)fouten en uitvoerige instructies met betrekking tot honoraria welke gerelateerd werden aan welstand en maatschappelijke positie. Uitoefening van de geneeskunde komt reeds in die tijd naar woeren als een veelomvattend beroep en blijft dat in alle perioden van grote bloei zowel in Egypte, India, de Arabische wereld als tenslotte in Griekenland. In de hele historie vanaf 2000 voor Christus tot 2000 na Christus omvat de omschrijving van een goed medicus, elementen van een fillosoof, natuurwetenschapper, priester/vertrouwenspersoon, tovenaar/mysticus en ambachtsman. Kortom een breed en multidisciplinair profiel wordt door de eeuwen heen als ideale conditie gezien voor een goede beroepsbeoefening. Hoogstens zien we enige verschuiving in de loop der tijd. Zo behoorden medici in Babylon (2000 voor Christus) tot de priesterkaste en verschoof ten tijde van Hippocrates - rond 400 voor Christus - de nadruk in de richting van de wijsbegeerte en natuurwetenschap, daarbij overigens ook nadrukkelijk wijzend op de noodzaak tot het bezitten of ontwikkelen van specifieke karaktereigenschappen (zie de eed van Hippocrates). Een arts heeft voor een adequate beroepsuitoefening altijd moeten beschikken over vele en verschillende (medische) competenties.

De explosieve groei van (sub)specialismen lijkt de aandacht af te leiden van noodzakelijke algemene karakteristieken van medisch hulpverleners. Het medisch onderwijs dat - mede als gevolg van de grotere aantallen studenten - deels afscheid moet nemen van de meester-gezel traditie, werkt dit in de hand. [2] De opleiding tot arts wordt van algemene klinische vorming steeds meer een optelsom van diverse mono-disciplinaire trainingsmomenten. Tijdens het klinisch onderwijs in een ziekenhuis of huisartsen praktijk is de oriëntatie van het onderwijs op het reële patiëntenprobleem weliswaar nog evident. 
maar het multidisci-plinaire aspect in het leerproces gaat goeddeels verloren. Het stageonderwijs volgt immers de infrastructuur van de (specialistische) gezondheidszorg en is als zodanig disciplinegebonden. Op zich vormt dit een efficiënte vorm van onderwijs waarbij gebruik gemaakt wordt van de didactische principes van de "encoding specificity" [3] en de "situated knowledge" [4]: het verschijnsel dat het onderwijsrendement toeneemt naarmate er meer gelijkenis is tussen de situatie waarin men iets leert en de omstandigheden waaronder men het geleerde naderhand in praktijk zal brengen. Een efficiënte leermethode voor een aantal medische competenties, maar met een prijskaartje: het verlies van andere, voor goed hulpverlenerschap even essentiële, competenties zoals de ontwikkeling van een holistische, geïntegreerde en multidisciplinaire benadering van patiënten en hun problemen.

Als eerste universiteit in Nederland koos de Universiteit Maastricht - destijds nog Rijksuniversiteit Limburg - voor een (patiënt)probleem georiënteerde structuur. Dit type onderwijs wordt onder meer gekenmerkt door een multidisciplinaire benadering van de te behandelen problematiek. Dit betekende een belangrijke breuk met de insluipende traditie om het medisch onderwijs op te delen in vele aparte disciplines zoals fysica, biochemie, anatomie en klinische vakken. In de loop van de opleiding tot basisarts verschuift in Maastricht het accent van multidisciplinair blokgroepsonderwijs naar patiëntgebonden praktisch medisch onderwijs in de vorm van co-assistentschappen. Ook in de co-assistentfase was er in Maastricht reden om de vigerende onderwijstraditie kritisch te beschouwen. Co-assistentschappen vormen zeker een beproefde onderwijsmethode, waarbij in de directe relatie tussen opleider, student en patiënt een belangrijke bijdrage kan worden geleverd aan de klinische vorming. Met de toename van het aantal studenten en het aantal subdisciplines ontstaat echter het gevaar dat de klinische kennis wel toeneemt, maar slechts in geringe mate het integratieve denken waarop (echte) medische expertise berust. [5] Dit is deels het gevolg van het verloren gaan van de multi-, trans en interdisciplinaire benadering van patiëntenproblematiek die zo kenmerkend is voor de 
blokfase, het thematisch gestructureerde deel van het curriculum in Maastricht. In een louter stagegebonden organisatie van het praktisch medisch onderwijs beperken studenten zich gemakkelijk tot deelaspecten van de gezondheidszorgproblemen waardoor er weinig integratie van de medische kennis plaatsvindt. Het disciplinegewijze in korte tijd aanbieden van veel kennis over een klein gezondheidszorggebied houdt immers het gevaar in, dat studenten verleid worden hun tijd te besteden aan te (sub)specialistische aspecten ten koste van meer algemene, voor hun latere beroepsuitoefening relevantere, thema's. [6] Zeker als voorbereiding voor (sub)specialistische vervolgopleidingen is in de basisopleiding het ontwikkelen van het vermogen tot geïntegreerd denken, en het leren zien van ziekteprocessen en condities in hun samenhang, essentieel. Tijdens specialistische vervolgopleidingen zal de eenzijdige nadruk die op de eigen discipline ligt - enkele "brede" vakken als algemene interne geneeskunde en huisartsgeneeskunde uitgezonderd - veel minder ruimte laten om deze vaardigheid als onderdeel van de medische competentie verder te ontwikkelen. Een belangrijke taak van de basisartsopleiding is derhalve de ontwikkeling van integratief denken, het zien van de patiënt als geheel en in zijn/haar maatschappelijke context, en niet als minder interessant of irrelevant omhulsel van een boeiend onderdeel (hart, baarmoeder, skelet). [7]

Een tweede gevaar vormt het feit dat niet alle delen van de gezondheidszorg in stages zijn ondergebracht waardoor interdisciplinaire aspecten tijdens de reguliere monodisciplinaire coassistentschappen beperkt aan bod komen. Met name geldt dit voor de zogenaamde basisdisciplines. [8] Aspecten van de geneeskunde die niet in de vorm van een co-assistentschap worden aangeboden, dreigen door de eenzijdige nadruk op het stagegebonden onderwijs onderbelicht te raken/blijven.

Ook dit leidt ertoe dat het probleemoplossend denken van de toekomstige arts, na de integrale benadering die kenmerkend is voor het blokonderwijs in de eerste jaren van het Maastrichtse curriculum, uiteindelijk weer sterk discipline gebonden wordt. De student dreigt hierdoor de samenhang tussen de diverse disciplines in de 
gezondheidszorg kwijt te raken, terwijl het vlot kunnen combineren van kennis uit verschillende disciplines essentieel is voor de latere beroepsuitoefening. Hierbij moeten studenten niet alleen routineproblemen kunnen oplossen maar ook overweg kunnen met het onverwachte en ongebruikelijke. Voor dit laatste is een diep begrip van alle relevante domeinkennis noodzakelijk. [9]

In ruime kring wordt inmiddels erkend dat de kwaliteit(en) van een basisarts niet simpelweg een optelsom vormt van de kennis en vaardigheden opgedaan tijdens theoretisch onderwijs, zelfstudie en stages. [10, 11] Met name in de laatste fase van de opleiding, tijdens de coassistentschappen, komen vele essentiële aspecten slechts impliciet aan bod (ethiek, attitude-bewustwording), of zijn niet duidelijk verankerd in het stageonderwijs omdat ze niet tot de specifieke verantwoordelijkheid van een bepaalde stage worden gerekend (kostenbeheersing, farmacokinethiek, maatschappelijke, sociologische epidemiologische facetten). Of, en in welke mate, door de basisarts expertise in dergelijke vraagstukken wordt ontwikkeld, is dan meer van het toeval afhankelijk dan het gevolg van een rationele onderwijsplanning. Om bovengenoemde redenen werden in 1994 in Maastricht stageoverstijgende klinische onderwijsactiviteiten ontwikkeld $[12,13]$ en vervolgens als structureel onderwijs programma geïmplementeerd tijdens de co-assistentschappen in het vijfde jaar. [6]

\section{Wat is de inhoud van dit type onderwijs?}

Stageoverstijgend klinisch onderwijs beoogt het bevorderen van het integratieve denken bij het klinisch handelen van studenten en het scheppen van aandacht voor aspecten die in de huidige uitoefening van de geneeskunde van belang zijn, maar in het vigerend stagecurriculum geen (herkenbare) plaats innemen. Het realiseren hiervan vraagt om een vrij divers onderwijsaanbod. In de nota "tweede fase onderwijs geneeskunde" [13] wordt geïnentariseerd welke aandachtsgebieden in de klinische fase onvoldoende aan bod komen en zich lenen voor stageoverstijgend klinisch onderwijs. (tabel 1) Eerder werd reeds op ruime schaal ervaring opgedaan met de 
ontwikkeling van attitudebewustwording programma"s en klinisch ethiek onderwijs tijdens de co-assistentschappen. [14]

Tabel r. Disciplines en aandachtsgebleden die een rol kunnen spelen bij de implementatie vain het stageoverstijgend klinisch onderwijs.

De genoemde aandachtsgebieden zijn niet limitatief en dienen om een indruk te vormen.

\begin{tabular}{|l|}
\hline ATTITUDE/ETHIEK \\
Medische Ethiek \\
Gezond-heidsrecht \\
Attitude \\
\hline DIAGNOSTIEK \\
Pathologie \\
Radiodiagnostiek \\
Fysiologie \\
Medische microbiologie \\
Klinische chemie \\
Klinische immunologie \\
Toxicalogie. \\
Isotopen \\
Klinische epidemiologie \\
\hline THERAPIE \\
Farmacotherapie \\
Radiotherapie \\
Fysiotherapie \\
Psychotherapie \\
Verpleegtechinieken \\
Anesthesiologie \\
Klinische besliskunde \\
\hline PSYCHO-MAATSCHAPPELIJK \\
Medische Psychologie \\
Medische Sociologie \\
\hline STRUCTUUR/FUNCTIONEREN GEZONDHEIDSZORG \\
Economie/kostenbeheersing \\
Gezondheidszorgbeleid \\
Technology assessment \\
Statistiek/kritisch lezen \\
\hline
\end{tabular}

NB Verschillende aandachtsgebieden, zoals bijwoorbeeld geriatrie, maken deel uit van meerdere indelingscategorieën. 
Stageoverstijgend onderwijs kan op verschillende wijzen worden geïmplementeerd. Gekozen is voor groepsonderwijs - met name casusbesprekingen - voor studenten uit verschillende klinische stages onder inhoudsdeskundige leiding volgens het klinische agora model (discussie over een patiëntencasus vanuit zoveel mogelijk invalshoeken), waarbij het denkpatroon rond de casus van belang is. Het gaat hierbij om (ervaring opdoen in) integratief denken bij klinisch handelen, met in acht neming van medisch ethische en gezondheidsrechtelijke aspecten, epidemiologische factoren, kostenbeheersing, etc.

Op grond van de steeds wisselende relevante thema"s, dwars door de hele geneeskunde, wordt gerekend op meerwaarde volgens de didactische principes van "voorkennisaktivatie" en "kenniselaboratie". $[15,16]$ Aangezien een belangrijk deel van de klinische groepsbesprekingen gewijd is aan het bespreken en oplossen van patiëntencasuïstiek komen gedurende het gehele klinisch curriculum immers steeds weer aspecten aan de orde vanuit andere disciplines dan die waarin op dat moment het co-assistentschap wordt gelopen. Door het voortdurend activeren van reeds aanwezige kennis, zal deze kennis beter bijblijven en geïntegreerd worden in de nieuw verworven kennis, en daardoor wanneer nodig beter toegepast kunnen worden. [5]

Het is van belang dat zo een stageoverstijgend onderwijs programma centraal wordt beheerd en inhoudelijk onafhánkelijk is van de "belangen" van het co-assistentschap.

Vanaf de invoering van het stageoverstijgend onderwijs programma is deze aanvulling op het "traditionele" stagegebonden klinisch onderwijs nauwgezet geëvalueerd. Na elke onderwijsbijeenkomst wordt door iedere student anoniem een programma-evaluatie formulier ingevuld. Deze data worden centraal geanalyseerd en in de soo-planningsgroep besproken.

De resultaten tonen grote waardering van de studenten voor dit type onderwijs. (figuur 1) 
Figuur 1. Programma-evaluatie stageoverstijgend onderwiji 5 ( 500 ) januari 2000 - december 2001 (schali 1 - 5)

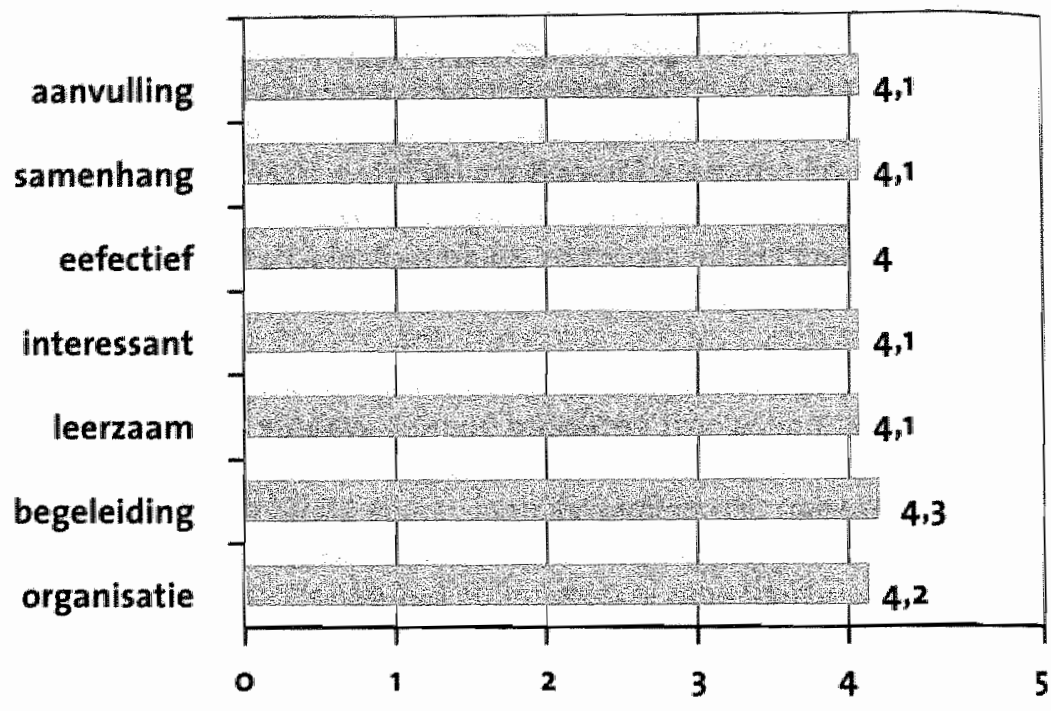

$(n=2362)$ Gewraged werd of het 500-programma een zinvolle aanvulling was op de co-assistentschappen en naar de onderlinge samenhang. Verder werd gevraagd naar de effectivitelt van de werkvorm, en of het 500 interessant, leerzaam, goed begeleid en goed georganiseerd was. ( 1 = zeer slecht, $5=$ zeer goed)

Bij het naderende afscheid van Harry Crebolder, exponent van een uitstervende generatie artsen voor wie de holistische benadering van patiënten en multidisciplinaire visie op patiènten problematiek vanzelfsprekend is, die met zijn transmuraal onderwijs experimenten de integratie tussen eerste en tweede lijns geneeskundige zorg. nadrukkelijk als zwaartepunt in het medisch onderwijs heeft gebracht, heb ik graag willen laten zien hoe onze visie in het stageoverstijgend onderwijs gestalte krijgt, en hoe hiermee succesvol wordt bijgedragen aan de opleiding van complete competente artsen. 


\section{Literatuur}

1. Lindeboom GA. Inleiding tot de geschiedenis der geneeskunde. Erasmus publishing Rotterdam, 7e druk, 1993

2. Essed GGM. De verloskundige opleiding van de basisarts. Bijblijven: eerstelijns verloskundige zorg. Houten, Bohn Stafleu van Loghum, 1994; 10/3: 10-6

3. Tulving $\mathbb{E}$, Thomson DM. Encoding specificity and retrieval processes in episodic memory. Psychological Review 1973; 80: 352-373

4. Leinhardt $G$. Situated knowledge: an example from teaching Professional Learning Conference, University of Lancaster, England, 1987

5. Boshuizen HPA, Essed GGM. Leren probleemoplossen in de stagefase; naar een didaktiek voor het klinisch onderwijs. In: Verslag landelijke dag studievaardigheden, Eindhoven: LOS, 1990

6. Essed GGM, Boshuizen HPA. Stage-overstijgend klinisch onderwijs te Maastricht. Medisch Contact 1993; 48: 1051-2.

7. Essed GGM. Onderwijs over de stages heen. Mediscoop 1993; 2: 10-11

8. Boshuizen HPA. De ontwikkeling van medische expertise. Academisch Proef-schrift, Rijksuniversiteit Limburg, 1989

9. Hatano G, Inagaki K. Two courses of expertise. In: Steven-son H, Azuma $\mathrm{H}$, Hakuta K. Child development and education in Japan. San Francisco: Freeman, 1986: 262-272 .

10. Association of American Medical colleges. Physicians for the Twenty-First Century. Report of the Project Panel on the General Professional Education of the Physicians and College Preperation for Medicine (GPEP-report). Washington, 1984

11. Metz JCM, Bulte JA, Paridon EJM. Basisarts: bevoegd en bekwaam. Beleidsgericht onderzoek co-assistentschappen. Zoetermeer: Ministerie Onderwijs en Wetenschappen, $199^{\circ}$

12. Essed GGM. Coördinatie Klinisch Onderwijs; jaarverslag 1987. Maastricht: Rijksuniversiteit Limburg, 1988

13. Essed GCM, et al. Nota Tweede Fase Onderwijs Geneeskunde; rapport van de curriculum begeleidingscommissie voor het vijfde en zesde studiejaar. Maastricht: Rijksuniversiteit Limburg, 1991 
14. Have HAMI ten, Essed GGM. Ethisch onderwijs in de klinische fase. Ned Tijdschr Geneeskd 1989; 133:687-689

15. Anderson RC. The notion of schemata and the educational enterprise. In: Anderson RC, spiro RC, Montague WE (eds), schooling and the acquisition of knowledge. Hillsdale NJ: Erlbaum, 1977

16. Schmidt HG. Activatie van voorkennis, intrinsieke motivatie en de verwerking van tekst; studies in probleemgestuurd onder-wijs. Academisch proefschrift, Rijksuniversiteit Limburg, 1982

Prof. dr. G.G.M. Essed, gynaecoloog, is hoogleraar methodiek van het klinisch onderwijs aan de UM. 


\section{Voor een paar dollars meer}

Harry Hillen.

In één van de klassieke cowboy films met Clint Eastwood gebeuren achteloos spannende dingen "voor een paar dollars meer". Een beetje succesfilm levert wereldwijd 100 miljoen dollar op. Spannend vermaak wordt duur en grif betaald.

Voor een paar dollars meer, om precies te zijn 12 per inwoner, kan in Centraal Afrika een voedings -en vaccinatieprogramma starten, waardoor de gemiddelde levensverwachting met 30 jaar kan stijgen. Spannende dingen, waarvoor de WHO geen geld bij elkaar kan krijgen.

Half Afrika is besmet met het HIV-virus, geld voor triple therapie is er niet, en Nederland is in rep en roer over wachttijden voor liesbreukoperaties.

Het onbehagen van een paar dollars meer heeft de visie en de overtuiging van Harry Crebolder geslepen. In discussies over gezond heidszorg, over het nieuwe geneeskunde curriculum en over de facultaire politiek zoekt Harry naar grote lijnen.

Debatten over gezondheidszorg gaan te vaak over geld, bij Harry over de inhoud van de zorg en de keuzen die wij daarin zouden moeten maken. Niet de techniek van de ingreep, maar het geluk van de patiënt.

Het nieuwe curriculum wordt door de Crebolder-visie van ziekte als life event en ziekte in de loop van verschillende levensfasen in hoge mate geraakt.

De Faculteitsraad onder Harry Crebolder keek met zorg naar het onvermogen om op één lijn te komen met universiteit en ziekenhuis.

In het gesprek met Harry komt vroeg of laat het gevoel van beperkte mogelijkheden voor zijn eerste patiënt in Tanzania ter sprake. Het opereren lukt nog wel, maar het doorgronden van de betekenis van ongemak en ziekte in een andere cultuur duurt langer. Het opzetten van een gezondheidscentrum en het organiseren van ketenzorg mikt 
op lange lijnen. Lijnen die gericht zijn op de best mogelijke zorg met respect voor de eigen cultuur van alle betrokkenen en met dokters die vertrouwen genieten, omdat ze bereid zijn een paar dollars meer te investeren.

Prof. dr. H.F.P. Hillen is Hoogleraar Interne Geneeskunde aan de UM. 


\section{Harry}

Cauke Kootstra.

De eerste keer dat de naam Harry Crebolder mijn trommelvliezen beroerde, was toen Co Greep, zeker 20 jaar geleden aan ledereen die het wel of niet wilde weten, vertelde dat hij een enorme slag geslagen had door de leider van het Withuis in Venlo naar Maastricht te halen. "Huisartsgeneeskunde zou nu doorbreken!"

Dat was lang geleden en daarna heb ik Harry incidenteel ontmoet. Heel plezierig, meestal casual. Samen in de UHD-commissie, waarin hij warme pleidooien hield. Dan wordt het heel serieus in september/oktober 1999 wanneer de medische staf zich beraad over het plotselinge ontslag van de toenmalige decaan Bonke. Harry was initiatiefnemer van de reactie van de facultaire wetenschappelijke staf. Brieven schrijven, woord voor woord wegend, want Harry let op de details. Het ontslag van Bonke had voor mij het fortuinlijke gevolg dat ik uitgenodigd werd de vacante plaats te bezetten, en wie zit in de Co Greepzaal tegenover mij bij de Faculteitsraad, inderdaad Harry Crebolder. It is a small world. Dat zou niet de enige plaats zijn waar we elkaar de volgende jaren gaan treffen. Met name zien we elkaar vaak op mijn kamer, waar Harry "even komt bijpraten". Dat houdt altijd een bespreking in van ten minste 3 punten die hij op een notitieblok reeds had opgeschreven. Punt voor punt wordt afgehandeld, met expressieve marfan-achtige gebaren. Vrijwel altijd hadden één of twee punten te doen met zijn mensen, zijn personeel. Bevordering tot UHD/hoogleraar, maar ook stond er altijd wel een aspect betreffende de positionering van de Huisartsgeneeskunde op de geheime agenda. Vaak leidde hij dit in door even terug te grijpen op wat ik de vorige keer over dat onderwerp had gezegd. Ik kreeg daarbij vaak het gevoel dat ik het zelf had bedacht. Dankbaar met de informatie die hij had verkregen verdween dan weer een tevreden Harry, niet om nu de "gedane zaken" te laten voor wat ze zijn. Al snel daarna werd de secretaris van de UHD-commissie gebeld, wanneer er weer vergaderd werd, dat hij verwachtte dat zeker dat en dat punt op de agenda zou staan en dat hij graag zou informeren na de vergadering hoe een en ander positief was besproken. En ojé als het 
niet positief was, dan was er weer werk aan de winkel.

Waar Harry het lobbyen heeft geleerd weet ik niet, waarschijnlijk is het ingebouwd, maar niet verworven, aangeboren!

Het bovenstaande heb ik wat badinerend geschreven, maar ik weet daadwerkelijk wel beter! Harry heeft de capaciteitsgroep uitgebouwd tot éen van de beste van het land, niet in zijn eentje, maar met zijn staf, waarin hij de besten uit het veld heeft samengebracht.

In een niet aflatend enthousiasme, met doorzetting en overtuiging, voor de goede zaak!

Harry, chapeau!

Prof. dr. G. Kootstra is decaan van de Faculteit der Geneeskunde aan de UM. 


\section{De verantwoordelijkheid voor de eigen professie: de inbreng van de opleiders in de huisartsopleiding}

Jan van Ree.

\section{Inleiding}

"De opleider blijft de belangrijkste onderwijzer, die nog meer dan woorheen een rol als docent moet vervullen. Door verbeteringen van de opleiding kan de huisarts zich als leermeester beter waarmaken ..... Verder lees ik niets over de kwaliteiten waaraan een huisartsopleider zou moeten voldoen. Riekt dit naar zelfgenoegzaamheid? Meer dan $50 \%$ van de opleiding wordt doorgemaakt bij een huisartsopleider. Bij alle plannen voor meer kwaliteit van de opleiding moet veel kritischer gekeken worden naar de kwaliteit van onze opleiders. Bij een zorgvuldige selectie van aspirant-opleiders moet aandacht worden besteed aan hun vermogen tot zelfreflexie, hun didactische en communicatieve vaardigheden, de verplichte inter- of supervisie en hun medisch technisch niveau. Hier moet het zwaartepunt liggen bij gesprekken over vernieuwing. Als haio's hun eigen opleiding mogen componeren zullen er heel wat noten gekraakt worden waar het de opleiders betreft!"

Deze hartenkreet uitte collega mevr. J. Boer in een ingezonden brief in Medisch Contact maar aanleiding van een publicatie in het eerste nummer van Medisch Contact in het jaar 2000 over de "Huisartsopleiding in het nieuwe millennium' (auteurs: لl. van Ree, Y. van Leeuwen en L. Wigersma). Bij lezing van deze ingezonden brief werd ik me bewust dat het onderwerp "de kwaliteit van de opleider" niet alleen zeer actueel is binnen de staven van de Nederlandse huisartsopleidingen, maar dat het ook leeft bij de huisartsopleiders zelf. Het lijkt erop dat dit het juiste moment is om de discussie te openen over de stappen die gezet moeten worden om de kwaliteit van de huisartsopleiders te verhogen. Het is bekend bij huisartsen dat een boodschap of advies pas goed overkomt en goed wordt onthouden alls de toehoorder er aan toe is. Dan pas valt het zaad in een vruchtbare akker! Welnu, ik denk dat huisartsopleiders eraan toe zijn om zich te bezinnen op hun rol binnen de opleiding en de kwaliteit ervan. 
Uit de bovenstaande reactie blijkt volgens mij dat de huisartsopleiders de verantwoordelijkheid willen nemen voor het verbeteren van hun opleiderrol met als doel de kwaliteit te waarborgen van de toekomstige huisartsen en dus hun opvolgers. Deze bijdrage gaat over de rol van de huisartscpleider in de huisartsopleiding van de toekomst en dus ook over de huisarts van de toekomst. De opleider is een belangrijke medewerker van de afdeling en in deze bijdrage gaat het over de vraag wat dit betekent voor de opleider en de opleiding van de komende generaties huisartsen. Harry Crebolder weten we, hecht zeer groot belang aan een grotere rol van praktiserende huisartsen in de huisartsopleiding en daarom wil ik mijn visie over de rol van de opleider, zoals ik zou willen dat deze zich in de toekomst gat ontwikkelen, weergeven.

De huisartsopleiding moest na zoveel jaren worden vernieuwd en aangepast aan de moderne ontwikkelingen en inzichten in scholing van volwassenen. Inmiddels is er een nieuw landelijk raamcurriculum voor de huisartsopleiding gemaakt, dat door de acht opleidingen in het land zal worden uitgewerkt en stapsgewijze geïmplementeerd zal worden, vanaf nu tot 2004 .

Voordat dit nieuwe curriculum gerealiseerd zal worden moet er veel werk worden verzet en er zullen harde noten moeten worden gekraakt. Immers, er moet veel veranderd worden en veranderen in het onderwijs is moeilijk, weten we. Moeilijk omdat hoe dan ook iedere verandering moeilijk is, maar ook omdat het verleggen van nieuwe accenten weerstanden op zal roepen.

\section{Modernisering van de opleiding}

Dat de opleiding moest worden vernieuwd was voor iedereen die bij de opleiding is betrokken, al jaren duidelijk. Er waren in de afgelopen vijfentwintig jaar wel de nodige organisatorische aanpassingen doorgevoerd maar in wezen was de opleiding al sinds de start niet veranderd, dus al 25 jaar oud. Inmiddels was het curriculum wel aangepast en vooral uitgebreid en dichtgemetseld met een overmaat aan onderwijsprogramma's. De organisatiestructuur van en de regulering rond de opleiding was zo complex geworden dat er 
inmiddels sprake was van aanzienlijke verstarring, een ongewenste situatie. In deze periode is op onderwijsgebied inmiddels ook erg veel gebeurd en er zijn fundamenteel andere onderwijstheoretische inzichten ontstaan. Zeker als het gaat over onderwijs aan volwassenen. Het was dus na al die jaren niet goed meer vol te houden dat de huisartsopleiding een opleiding van deze tijd was. Het was voor leder duidelijk dat de opleiding vernieuwd moest worden. Niet alleen maar een nieuw jasje, of een nieuwe structuur. maar vooral ook moesten de uitgangspunten van het onderwijs, de aanpak van de opleiding in de praktijk en de inhoud van het onderwijs op het institu ut (afdeling) worden vernieuwd. Bij het uitwerken van de principes van de nieuwe aanpak in het nieuwe raamcurriculum, werd daarom veel aandacht geschonken aan de plaats van de opleider bij het opleiden en werd gezocht naar een vorm die recht zou doen aan de betekenis van de rol van de opleider.

\section{Accent van de opleiding in de praktijk}

Waar moet het hoofdaccent van de opleiding liggen? Binnen de praktijk of bij de afdelingen? Bij de huisartsopleider of bij de staf, de begeleiders op de afdeling? Dit zijn essentiële vragen die bepalend zijn voor de wijze hoe de rol van de huisartsopleider moest worden ingevuld. Een belangrijke vraag is natuurlijk of er argumenten zijn die zeggen dat het accent van de opleiding meer in de praktijk, bij de opleider moet liggen en minder bij het instituit?

Argumenten dat dit wel zo zou moeten zijn komen uit wetenschappelijk onderzoek naar effectiviteit van 'stage gerelateerd onderwijs'. Ook de huisartsopleiding is een opleiding waarin a.s. huisartsen in op stageplaatsen bij opleiders in de praktijk, aan de hand van de praktische patiëntcontacten, al werkende, het vak "huisartsgeneeskunde' leren. Daarnaast voegt het onderwijs op de afdeling de wetenschappelijke onderbouwing aan het huisartsenvak toe. Op deze manier kunnen we zeggen dat er in de huisartsopleiding sprake is van een wetenschappelijke opleiding. In feite worden alle specialistenopleidingen op vergelijkbare manier gerealiseerd, dus werken en leren. De huisartsopleiding is een driejarige opleiding 
waarin in het midden ook nog een intramurale stage valt van zes tot negen maanden. Maar over deze externe leerwerkperiode praten we nu niet. ledere week komen de huisartsen in opleiding (haio's) een dag terug naar het de afdeling. Deze afdeling is onderdeel van een van de afdelingen huisartsgeneeskunde van de medische faculteiten. Op die dag is er sprake van theoretische onderbouwing van het praktische handelen en is er veel ruimte voor persoonlijke reflectie op eigen handelen. Zowel de praktijkstage als de theoretische terugkomdag (TKD) zijn belangrijke, noodzakelijke onderdelen van de opleiding. Maar waar leert de haio nu het vak? Of: welk onderdeel is nu uiteindelijk beslissend voor de kwaliteit van het product? De TKD of de stage of toch allebei?

Onder andere uit het onderzoek van B. de Vries (1988) blijkt dat er een paar belangrijke factoren zijn aan te wijzen die het leereffect in een leerwerk situatie bepalen.

Dit zijn in afnemende volgorde van belangrijkheid:

1. stageplaatskenmerken:

a. Kwaliteit van het werk

- realiteit van het werk

- mate van zelfstandigheid

- mate van afwisseling

b. Intensiteit van de begeleiding

- samenwerking begeleiders

- hoeveelheid feedback

2. stagiairkenmerken

- inzet/leerhouding

- theoretisch inzicht

3. onderwijskenmerken

- begeleiding met name. supervisie

- voorbereiding van de stagiair

4. onderwijsinterventie (de gegeven onderwijsprogramma's) 
Hieruit blijkt dat de stageplaatskenmerken het belangrijkste zijn voor het leereffect bij een dergelijke opleiding en dat onderwijsinterventies de geringste invloed hebben. De onderwijsprogramma's (onderwijsinterventies) zoais die vanuit een instelling cq. de afdeling verzorgd worden hebben, zeker tot groot verdriet van de onderwijsgevers, veel minder leereffect dan men zou wensen. Wat wel belangrijk is als onderdeel van het opleiden is de supervisie van de opleiding, de bewaking van het onderwijs in de praktijk en het voorbereiden op de stage. Voor de huisartsopleiding zou men zich altijd moeten afvragen: Wat maakt de opleider ervan en wat kan de haio verwachten tijdens de opleiding?

De situatie in de opleidingspraktijk is dus heel belangrijk voor de uiteindelijke kwaliteit van de opleiding! De kwaliteit van het werk wat de haio kan doen, de inhoud, de afwisseling en vooral de realiteitswaarde, in de zin van goede afspiegeling van de werkelijkheid van in de praktijk aangeboden morbiditeit c.q. klachten van de patiënten die de haio te zien krijgt, is zeer bepalend voor de kwaliteit van de opleiding en dus van het afgeleverde product "jonge huisarts'. Degene die de inhoud van het werk bepaalt, bepaalt tevens voor het grootste deel wat wordt geleerd! En dat is natuurlijk de opleider in de eerste plaats! In de praktijk wordt geselecteerd wie door de 'assistent' gezien mag worden. Al of niet uitgesproken 'afspraken' tussen opleider en diens doktersassistente bepalen de patientenstroom naar de 'assistent'. Vooral jongeren, of de ouderen, of de klagers of de niet-particulier verzekerden kunnen het hoofdbestanddeel vormen van de groep patiënten die de haio in zijn opleiding ziet. En dat beperkt natuurlijk de mogelijkheid om te leren. Gelukkig is binnen de huisartsopleiding deze slechte opleidingsituatie niet meer aan de orde doordat in het laatste jaar van opleidingpraktijk gewisseld wordt. Maar zonder twijfel zal ook nu nog attitude en daarmee gepaard gaande opvattingen van de opleider invloed hebben op de patiëntenstroom naar de haio. Van een brede patiëntenstroom, wat betreft aangeboden klachten, zal deze het toch moeten hebben als hij straks goed en generalistisch opgeleid, in een eigen praktijk moet gaan starten!

Nog geheel onbekend is de invloed die de doktersassistente heeft op 
de kwaliteit van de opleiding ter plaatse. Is er een vooroordeel over haio, hoe gaat de communicatie met de haio, hoe komt de haio over? Sympathiek of niet zo, persoonlijk voorkeuren zullen zeker een rol spelen. Naar de betekenis van de doktersassistente binnen de opleiding zal binnenkort een onderzoek gestart worden. Deze zou wel eens groter kunnen zijn dan we nu nog denken!

\section{Grenzen aan de verantwoordelijkheid van de opleiders}

De huisartsopleider zal de verantwoordelijkheid moeten nemen voor de kwaliteit van de stageplaats en voor de begeleiding ter plaatse van de haio! Hij zal zich verantwoordelijke moeten voelen voor het opleiden. Bij deze verantwoordelijkheid moeten ook de consequenties ervan expliciet gemaakt worden. De consequenties moet de opleider zelf aangeven onder andere door te bepalen waar de grens van zijn kunnen ligt. Daarna is de afdeling er verantwoordelijk voor dat de opleider zijn taak kan realiseren. Bijvoorbeeld door aan de opleider scholing aan te bieden of door praktijkbezoeken te realiseren waar lacunes aan het licht moeten komen. De opleiders staan er niet alleen voor want een belangrijk deel, het bewakende en ondersteunende deel, blijft toch bij de afdeling liggen. De opleider zal eisen aan de afdeling kunnen stellen om zijn rol waar te kunnen maken. De ondersteuning door de afdeling is dus geen gunst die de opleider kan vragen maar een eis die de opleider moet stellen om de verantwoordelijkheid waar te kunnen maken.

Pas als opleiders deze inzet van het instituut opeisen will ik hen serieus nemen. Dan pas neemt de opleider de verantwoordelijkheid waarnaar in feite in de ingezonden brief naar wordt gevraagd. De inzet van de staf van de huisartsopleiding bij de begeleiding van de opleiders kan niet genoeg worden benadrukt. De samenwerking moet gericht zijn op het opheffen van de lacunes bij de opleiders die zijzelf hebben vastgesteld naar aanleiding van reflectie op de persoonlijke consequenties van de verantwoordelijkheden. Kunnen hao's dit? Dit is de eerste noot die we moeten kraken, al zal collega Boer dat niet meteen zo hebben bedoeld toen ze het over de noten had die gekraakt moesten worden. 


\section{Opleiders roepen om meer verantwoordelijkheid}

Maar willen de opleiders wel een dergelijke omslag in verantwoordelijkheden? En zo ja, onder welke voorwaarden kan en kunnen zij dat realiseren? De antwoorden hierop zijn nog niet te geven. De eerste berichten uit de Vereniging van Opleiders zijn zeer positief. Het is wel zeker dat we aan het begin staan van een proces waarin duidelijk moet worden hoe dit nu precies gerealiseerd kan worden. Het begin is gemaakt met een proces naar actieve (d.w.z. door de opleiders zelf geïnitieerde) en bewuste (door de opleiders) zelf uitgekozen deskundigheidsbevordering als opleider. Dus een opleiderscholing waarin de opleiders zelf het voortouw nemen en zelf vragen om de individuele steun die nodig is om deskundigheid als opleider te verwerven. Nu nog moeten de opleiders er vaak door de afdelingen met de haren bij worden gesleept als het gaat om deelnemen aan (na)scholingsprogramma's van de afdeling. Komt dat omdat het programma niet interessant is, of niet relevant voor de huidige situatie? Of past het programma niet bij een individuele opleider omdat die eigenlijk behoefte aan heel andere scholing? Uit de jongste ervaringen van de eerste groep huisartsopleiders met de nieuwe verantwoordelijkheid als opleider, blijkt grote bereidheid om te leren hoe dat moet. Opvallend is er geen afwezigheid op de scholingsdagen voor deze opleiders.

Kortom, het is voor de afdeling belangrijk om eerst te ervaren en te leren waar de steun voor de opleider moet liggen en hoe dat moet worden gerealiseerd. Dat zal heel wat energie vragen zoals de hele verandering van de opleiding veel energie kost en zal kosten in de komende jaren.

\section{Geen vrijblijvendheid}

De keuze voor deze rol voor de opleider is niet vrijblijvend en er zullen daarom nog wat andere en nog heel wat hardere noten moeten worden gekraakt.

Wie of wat zijn de nog hardere noten? Allereerst is dat de beroepsgroep van huisartsen zelf. Er zal pas sprake zijn van een 
volwaardige opleiderschap als u door de beroepsgroep huisartsen beter wordt gewaardeerd en het opleiderschap een onderscheiding voor deskundigheid is! Opleider word je niet zomaar! Tot nu toe is vanuit de collega's weinig inzicht getoond in het belang van het opleiderschap voor het voortbestaan van de huisartsgeneeskunde. Er is nog steeds een wereld van verschil tussen huisartsen en specialisten als het gaat over de waardering van het opleiderschap. Een specialistopleider wordt expliciet als zodanig door zijn collega's erkend. Opleider zijn is een erkenning van kwaliteit, het is een selecte groep die aan hoge eisen van deskundigheid voldoet. Vaak worden huisartsopleiders nog steeds gezien als collega's die hun te grote praktijk niet alieen aankunnen en daarom goedkope hulpkrachten inhuren.

Dit zou niet zo moeten zijn; daarom zullen opleiders moeten laten zien dat opleiden een complexe en specifieke deskundigheid is. Ze zullen moeten tonen dat opleiders huisartsen zijn met oog voor de toekomst van de huisartsgeneeskunde, verantwoordelijkheid nemen voor de beroepsgroep en geen gelegenheidsgevers. We zullen van onze beroepsorganisaties moeten eisen dat zij vierkant achter de opleiders gaan staan. De beroepsgroepen LHV en NHG zullen zonder beperking de nieuwe rol van de opleiders moeten steunen, inhoudelijke en materieel. Zeker nu er grote behoefte is aan huisartsen zal een goede opleiding meer kandidaten aantrekken. Op deze manier dragen de opleiders bij aan de invulling van de behoefte aan meer huisartsen in de toekomst. Er bestaat hier geen vrijblijvendheid!

\section{Veranderingen op de afdelingen}

De hardste noten die moeten worden gekraakt, betreffen echter de afdelingen. Er is reeds vermeld dat veranderen binnen het onderwijs moeilijk is en grote inspanning kost. En ook het realiseren van de nieuwe opleiding kost dat maar vooral is grote vastberadenheid om het te realiseren nodig. Het zal een hele klus zijn om de noodzakelijke verandering te bewerkstelligen waarbij het accent van de opleiding niet meer op de terugkomdagen op de afdelingen ligt, maar op de 
praktijk, op de ondersteuning van de opleider en op de directe begeleiding in de stagepraktijk. De afdeling moet beschikbaar zijn om de opleiders te vormen, te steunen en te helpen. De stafleden zullen ter plaatse, dus in de praktijk, moeten begeleiden en met opieider en haio overleggen over de stand van zaken, over het bereiken van de leerdoelen, over maatregelen die daarvoor eventueel nodig zijn. De afdelingen moeten zich realiseren dat fundamentele verandering van de opleiding nodig is, willen ze in de toekomst van een moderne opleiding kunnen spreken waar jonge artsen voor kiezen omdat ze zich daarin persoonlijk kunnen ontploolen. Ik denk wel dat de tijd voor deze accentverschuiving rijp is maar moeilijk zal het wel zijn. Bij de realisering van de nieuwe rol van de opleiders zullen nog veel belemmeringen optreden. Mijn ervaring is dat de belemmeringen alleen maar in gezamenlijkheid kunnen worden opgelost. Een stimulerende houding en een actieve inzet van de opleiders die expliciet hun verantwoordelijkheid nemen, zullen veranderingen binnen de afdelingen gemakkelijker maken. De tekenen uit de Maastrichtse huisartsopleiding voor een positieve ontwikkeling van de rol van de opleider en de inzet van de opleiding zijn zeer hoopgevend.

Prof. dr. Jan W. van Ree is hoogleraar huisartsgeneeskunde aan de UM en portefeuillehouder huisartsopleiding. 


\section{Harry Crebolder en de Experimentele Kaderopleiding Huisartsen}

Jan van Es.

Harry Crebolder neemt afscheid van de universiteit. Dat is een vreemde sensatie, want hij oogt nog jong, ondanks zijn grijze haren; bijna jongensachtig. Het overviel mij daardoor wel toen de redactie van deze afscheidsbundel mij uitnodigde een bijdrage te leveren: is hiij al zó ver dat hij het leger der emeriti komt versterken! Ik ken Harry al tientallen jaren. Aanvankelijk was hij voor mij de huisarts die jarenlang met zijn wrouw Emma in Oost-Afrika had gewerkt, om daarna een spraakmakend gezondheidscentrum "Het Withuis' in Verilo tot stand te brengen. I $\mathrm{k}$ had altijd veel bewondering voor artsen die in de derde wereld werkten aan een betere gezondheidszorg. Met eigen ogen had ik gezien wat dat betekende toen mijn zoon vier jaar lang in Ghana werkzaam was. Dat Harry"s vroulw Emma prachtige gedichten schreef en bovendien lessen gaf in Swahili aan toekomstige werkers in Afrika gaf nog een extra positieve dimensie aan het beeld dat ik al van dit echtpaar had.

Jarenlang hadden wij niet rechtstreeks met elkaar te maken. Wij ontmoetten elkaar wel bij gelegenheden als de jaarlijkse NHG congressen, tot er een reden kwam om nader met hem in contact te komen. De achtergrond hiervan was het volgende:

Eind 1982 bood de minister van Onderwijs en Wetenschappen Deetman de nota Taakverdeling en Concentratie in het wetenschappelijk onderwijs aan de Tweede Kamer aan. Met de voorgestelde 'TVC operatie' werd beoogd door vergaande structurele maatregelen de schade te minimaliseren die door noodzakelijk geachte bezuinigingen in het wetenschappelijk onderwijs zouden kunnen ontstaan. Deze maatregelen waren vergaand, vakgroepen werden opgeheven of tot samengaan met andere gedwongen, posities van hoogleraren en medewerkers werden aangetast; hele faculteiten werden opgeheven. Dit lot dreigde ook een van de medische faculteiten, maar dit gevalar werd afgewend. Positief was dat maatregelen werden genomen om de in ontwikkeling zijnde universitaire huisartsgeneeskunde op twee manieren extra ondersteuning te bieden. In de eerste plaats werden de faculteiten van de Vrije Universiteit en van de toenmalige Rijksuniversiteit 
Limburg aangewezen om de huisartsgeneeskunde verder te ontwikkelen, waarvoor zij een extra financiering kregen. In de tweede plaats werd een fonds in het leven geroepen dat de opleiding van een aantal huisartsen tot wetenschappelijke onderzoekers mogelijk maakte Dit fonds werd bij NWO ondergebracht.

Een andere ontwikkeling was de verschijning van het advies van de Raad van Advies voor het Regeringsbeleid (RAWB) over het medischwetenschappelijk onderzoek in Nederland. Een van de conclusies van dit rapport was dat het patiëntgebonden onderzoek in Nederland over het algemeen zwak was. Omdat dit type onderzoek uit een oogpunt van de gezondheidszorg van veel belang werd geacht werd door de toenmalige ministeries van $0 \& W$ en WVC besloten dit een extra impuls te geven door een Stimuleringsprogramma Gezondheidsonderzoek (SGO) in het leven te roepen. Hiervoor werd een budget van 40 miljoen gulden beschikbaar gesteld. Een Adviesgroep zou leiding aan dit programma geven dat tot doel had wetenschappelijk onderzoek tot ontwikkeling te brengen op een aantal gebieden die een relatieve achterstand vertoondem. De RAWB had in zijn rapport al een aantal thema's aangegeven die voor stimulering in aanmerking zouden komen, waaronder reumatische aandoeningen, CARA, psychische problematiek, revalidatieonderzoek en gezondheidszorgonderzoek. Omdat de regel dat goed wetenschappelijk onderzoek nieuw wetenschappelijk onderzoek genereert op deze gebieden niet op kon gaan, ontwikkelde de Adviesgroep SGO een bijzondere aanpak: de 'top-down' procedure. De Adviesgroep bepaalde in grote lijnen op welke manier en op welke gebieden wetenschappelijk onderzoek zou worden gestimuleerd, riep in de loop van de tijd voor leder onderdeel een programmacommissie in het leven die een plan van aanpak moest opstellen; uit discussies. en overleg met de Adviesgroep volgde een plan van aanpak, dat via site-visits door de Adviesgroep in zijn ontwikkeling werd gevolgd.

Toen het deelprogramma 'gezondheidszorgonderzoek' aan de orde kwam, een term waar veel onder gevangen kan worden, viel na veel discussie de keuze op de huisartsgeneeskunde. Immers: mede door de gestage toename van het aantal chronisch zieken was te verwachten 
dat de taken van huisartsen uitgebreid zouden worden, een ontwikkeling die nog versterkt werd door de toenemende tendens taken van de tweede- naar de eerstelijnsgezondheidszorg te verschuiven, uitgedrukt in het begrip substitutie.

De opleiding van huisartsen diende daarop voorbereid te zijn door aanstaande huisartsen meer klinische kennis en vaardigheden bij te brengen. Besloten werd een experimentele kaderopleiding huisartsen in het leven te roepen, waarin een beperkt aantal huisartsen zodanig op klinisch en op wetenschappelijk gebied zouden worden opgeleid dat zij als docent die kennis aan huisartsen konden overdragen. (teaching the teachers)

Voor de ontwikkeling van deze opleiding werd een programmacommissie in het leven geroepen, waarin ik zelf ook zitting had, terwijl de praktische organisatie en begeleiding in handen werd gelegd van de vakgroep huisartsgeneeskunde van de Universiteit Maastricht, waar Harry Crebolder leiding aan dit programma zou geven. Onze keuze was op deze vakgroep gevallen orndat de Universiteit Maastricht in het kader van de eerder genoemde TVC operatie de huisartsgeneeskunde als aandachtsveld had toegewezen gekregen en bovendien in onze ogen in onderwijskundig opzicht hoge ogen gooide.

Het gevolg was dat Harry en ik van toen af aan veel met elkaar te maken kregen.

In de opvattingen van de Adviesgroep zou de beoogde opleiding een duidelijk academisch karakter moeten bezitten. Er werd van uitgegaan dat deze geen schools karakter zou moeten krijgen en de verwachting was dat degenen die deze opleiding zouden gaan volgen initiatiefrijke mensen zouden zijn die de kwaliteit van de huisartsgeneeskunde een stevige impuls konden geven. Er werd veel waarde gehecht de trainees ook een opleidingsperiode in het buitenland te laten volgen, waardoor naar verwachting nieuwe perspectieven konden worden geopend en internationale contacten tot stand zouden. Dat was immers de ervaring van specialisten die als onderdeel van hun opleiding een tijdlang in het buitenland hadden gewerkt. De trainees zouden ook binnen Nederland op enkele, door henzelf geselecteerde gebieden klinische en poliklinische ervaring 
opdoen. Naast het verwerven en uitdragen van de opgedane klinische kennis was het opdoen van praktische ervaring de kern van de opleiding.

De opleiding, die 2-3 jaar zou duren, zou voor ieder van de negen deelnemers op maat worden gemaakt. Een van de initiatieven van Harry was dat ook een aantal 'dimensies' zou worden vastgesteld, huisartsgeneeskundige elementen, die aan het opdoen van klinische ervaring een huisartsgeneeskundige sturing zouden geven.

Voorbeelden van deze dimensies waren: de relatie eerste en tweede lijn, thuiszorg, gezinsgeneeskunde, preventie en surveillance en technology assessment. Verder werd, min of meer analoog aan een ander SGO stimuleringsprogramma, namelijk op het gebied van de revalidatiegeneeskunde, een aantal blokcursussen in de opleiding opgenomen.

Het veld, met name het Interuniversitair Overleg Huisartsgeneeskunde $(\mathrm{IOH})$ verzette zich aanvankelijk tegen deze SGO plannen. Vooral zette kwaad bloed dat het $1 \mathrm{OH}$ als gevolg van de gehanteerde top-down benadering niet betrokken was bij de opzet en uitvoering van het programma. Het was de niet benijdenswaardige taak van Harry om binnen dat forum de SGO plannen te verdedigen, terwijl hij anderzijds in de programmacommissie de opvattingen van het $1 \mathrm{OH}$ uiteen moest zetten. Van beide taken heeft hij zich goed en met verve gekweten. Dit is maar éen voorbeeld van de moeilijke taak die Harry moest vervullen. Hij kwam ook vaak knel te zitten tussen de eisen en wensen van de programmacommissie en de houding van de trainees, die vaak moeite hadden het complexe programma, vooral wat betreft de buitenlandse stages te volgen. In de ogen van de programmacommissie stelden sommige trainees zich veeleisend op, onvoldoende beseffend aan welk een mooi en royaal programma zij konden deelnemen. Harry moest, terzijde gestaan door de nlet aflatende Jos op 't Root, met beide kanten in vrede proberen te leven. Uiteindelijk werd voor iedere deelnemer een opleidingsprogramma vastgesteld dat in een zogenaamd leercontract werd vastgelegd. $\mathrm{Er}$ werden halfjaarlijkse terugkomdagen en blokcursussen 
georganiseerd waarop de deelnemers hun ervaringen konden uitwisselen en overleg konden plegen met hun hoofdbegeleider. De buitenlandse stages werden in Montreal, Canada of in Edinburgh, Schotland, gevolgd. Een kleine delegatie van de begeleidingscommissie had zich ter plaatse over de mogelijkheden hiertoe georiënteerd.

Het programma was ambitieus en zwaar. Er werden hoge eisen gesteld aan alle spelers, zowel degenen die werden opgeleid als aan hun begeleiders en docenten. De doelstelling topkader te ontwikkelen was wellicht te hoog gegrepen; toch heeft het een voorbeeidfunctie gehad voor de naderhand, ook met steun van de Adviesgroep SCO ontwikkelde Kaderopleiding Huisartsgeneeskunde. Hierin kunnen huisartsen zich op door hen gekozen gebieden binnen de huisartsgeneeskunde nader bekwamen. Hierbij ontbreekt echter de mogelijkheid van het volgen van buitenlandse stages, een ontwikkelingsmogelijkheid waaraan de Adviesgroep SGO destijds sterk hechtte.

Zeven van de negen deelnemers volbrachten hun opleiding. Het merendeel van hen vervulde na afloop een staf- of kaderfunctie bij een van de universitaire vakgroepen huisartsgeneeskunde of bij het NHG.

Harry Crebolder heeft onmiskenbaar in belangrijke mate tot de verwerkelijking van de Experimentele Kaderopleiding Huisartsen bijgedragen door de van een realistisch inzicht getuigende wijze van leiding geven aan dit programma. Ik denk dat hij daarmee op zijn eigen gedreven wijze ook voor de versterking van de wetenschappelijke basis van de huisartsgeneeskunde een belangrijke bouwsteen heeft geleverd. 


\section{Literatuur}

1. Crebolder HFJM, Root JMH op 't, editors. The Dutch (experimental) SGO core training for general practitioners.

Final reports of the participants. Maastricht:

Vakgroep Huisartsgeneeskunde, 1996

2. Dinant GJ, Crebolder HFJM, Root JMH op 't.

De SGO-Kaderopleiding Huisartsen. Een eerste verslag. Medisch Contact 1992: 47: 913-4

3. Dinant GJ, Filion-Laporte L, Root JMH op 't, Crebolder HFIM. The Dutch advanced training program for general practitioners, an international initiatieve. Eur.l.Gen.Pract. 1995;1:121-3

Dr. J. C. van Es is emeritus hoogleraar huisartsgeneeskunde en voorzitter van de Adviesgroep (thans Commissie) SGO. 


\section{Kaderopleiding Huisartsgeneeskunde}

\section{Maarten Klompen Ted van Essen.}

Met het ontwikkelen van het standaardenbeleid heeft het Nederlands Huisartsen Genootschap (NHG) vanaff 1990 richting gegeven aan een kwaliteitsbeleid voor de Nederlandse huisartsgeneeskunde. Geleidelijk werd daarbij duidelijk dat het maken en publiceren van al die richtlijnen bepaald nog geen garantie is dat huisartsen deze ook in de dagelijkse praktijk toepassen.

Daarom startte het $\mathrm{NHG}$ in de jaren daarna met het maken van materialen om deze implementatie te ondersteunen.

Deskundigheidsbevorderingspaketten, toetsen, praktijkvoeringsmateriaal, patiënten folders en patiëntenbrieven zijn daar voorbeelden van.

De Landelijke Huisartsen Vereniging (LHV) stelde nascholingscoördinatoren aan in de districten om met behulp van deze producten de huilsartsen te helpen bij het opzetten van regionale cursussen. Toch bleef de implementatie van die stroom aan nieuwe richtlijnen een moeizaam proces.

Uiteindelijk stelden NHG en LHV samen in 1998 de nota "Kwaliteit op Koers" op, een beleidsplan waarin de hoofdlijnen werden geschetst van een structureel en systematisch kwaliteitsbeleid voor de Nederlandse huisartsgeneeskunde. Dit beleidsplan vormde de concrete uitwerking van het eerder door het NHG ontwikkelde "Kwaliteitssysteem Huisartsgeneeskunde".

In de plannen van Kwaliteit op Koers staat het werken volgens de kwaliteitscyclus centraal. Daarbij wordt steeds eerst een doel gesteld, vervolgens door gegevensverzameling bezien waar de feitelijke situatie afwijkt en vervolgens via gerichte acties naar verbetering gestreefd. Tenslotte worden weer gegevens verzameld om te zien of de gewenste doelen zijn bereikt. Daarmee is de kwaliteitscyclus rond en kan er een nieuw doel worden gesteld.

In de plannen van Kwaliteit op Koers is een centrale rol weggellegd voor kwaliteitsteams in de districten, die de ondersteuning moeten bieden aan praktijken bij het gericht en systematisch werken aan kwaliteitsverbetering.

Om hen op deze taak voor te bereiden dienen de functionarissen uit deze kwaliteitsteams getraind te worden. Dat schept de noodzaak tot 
een kaderopleiding, een belangrijke bouwsteen in het nieuw in te richten kwaliteitsbeleid. Aan het tot stand komen van deze kaderopleiding wordt op dit moment hard gewerkt.

Al zeker 10 jaar geleden voorzag Harry Crebolder de noodzaak van een dergelijke kaderopleiding en mede dank zij zijn inspirerende en vasthoudende inbreng in de afgelopen jaren is een dergelijke kaderopleiding thans heel dichtbij. Hieronder volgt allereerst een korte historische schets, vervolgens de huidige stand van zaken en tot slot het toekomstperspectief voor de Nederlandse Kaderopleiding Huisartsgeneeskunde.

\section{Experimentele Kaderopleiding Huisartsgeneeskunde}

Begin jaren ' 90 is op initiatief van het Stimuleringsprogramma Gezondheidsonderzoek (SGO) een programma opgezet van waaruit een beperkte groep van zo'n 5 tot 10 huisartsen zich gedurende een aantal jaren - deels ook in het buitenland - kon verdiepen in een van de klinische deelgebieden van de huisartsgeneeskunde. Doel was een kader te vormen dat daarna een leidinggevende rol zou kunnen gaan vervullen bij de verdere ontwikkeling van de huisartsgeneeskunde. De Capaciteitsgroep Huisartsgeneeskunde van de Universiteit Maastricht kreeg de supervisie over deze experimentele opleiding en Harry Crebolder had daar een belangrijk aandeel in. Toen het programma uiteindelijk in 1996 formeel werd afgesloten bleken zeven van de negen deelnemers de opleiding met succes te hebben doorlopen.

\section{Project Kaderopleiding Huisartsgeneeskunde}

Het hierboven beschreven experiment leverde niet alleen zeven opgeleide huisartsen af, het had nog een ander gevolg. Dat was het voorstel om opleidingen te starten waarin huisartsen zich aanvullend zouden kunnen scholen in een klinisch deelgebied of in vaardigheden als onderwijs geven, kwaliteitszorg, wetenschappelijk onderzoek of gezondheidszorgmanagement.

Het doel van een dergelijke kaderopleiding was tweeledig. Allereerst zou het individuele huisartsen de mogelijkheid bieden van verdieping 
en daarmee een persoonlijk carrièreperspectief. Anderzijds zou het ook de beroepsgroep extra kansen bieden: als onderdeel van het kwaliteitsbeleid van huisartsen levert kadervorming een belangrijke bijdrage aan verdere professionalisering van het vakgebied en betekent het een vorm van ondersteuning voor alle huisartsen. In een eveneens door SGO gefinancierd vervolgproject Kaderopleiding Huisartsgeneeskunde is vervolgens tussen 1995 en 2000 gewerkt aan de contouren van een dergelijke kaderopleiding. Er werd een coördinatiepunt ingericht bij het $\mathrm{NHG}$. In de stuurgroep waren $\mathrm{NHG}$, $\mathrm{LHV}, \mathrm{SGO}, 1 \mathrm{OH}$ en enkele externe deskundigen vertegenwoordigd. Harry Crebolder was als lid van deze stuurgroep een van de grote motoren achter de plannen en hij bleef er in geloven, ook in tijden dat de ideeën nog weinig draagvlak hadden.

Binnen het project zijn uiteindelijk door opleidingscommissies eindtermen geformuleerd voor kaderopleidingen in zeven klinische deelgebieden, te weten: astma/COPD, diabetes mellitus, cardiovasculaire aandoeningen, gastro-enterologie, geestelijke gezondheidszorg, palliatieve zorg en urogynaecologische aandoeningen. De eindtermen zijn allemaal in een vast format gegoten en voorzien van een globaal opleidingsplan.

Daarnaast zijn door nog eens vier opleidingscommissies eindtermen en cursusplannen gemalakt voor de meer functiegerichte opleidingen kwaliteitszorg (in samenwerking met de WOK), medisch onderwijs, gezondheidszorgbeleid en -management en wetenschappelijke vorming (in samenwerking met de Wetenschappelijke Vereniging van Vlaamse Huisartsen).

Het eindrapport is door de stuurgroep in 2000 aangeboden aan de besturen van NHG en LHV met het advies een en ander verder te ontwikkelen binnen het kader van het kwaliteitsbeleid van de beroepsorganisaties.

\section{Internationaal perspectief}

Ook in internationaal verband pleit Harry Crebolder al vele jaren voor het inrichten van kaderopleidingen. $\mathrm{Hij}$ doet dat als Nederlandse vertegenwoordiger binnen EURACT, de organisatie van opleiders in 
Europa, en een van de drie belangrijke working parties van de $5 I M G$, de Europese afdeling van de WONCA. Daar wordt al lange tijd gesproken over de wenselijkheid van een opleidingscontinuüm van basisopleiding, huisartsopleiding en postacademische opleidingen. Vooral in Engeland heeft dit principe van "life long learning" al enigszins vorm gekregen. Daar worden door enkele universiteiten ook al postacademische opleidingen voor huisartsen georganiseerd (higher professional education).

En onlangs organiseerde Harry Crebolder samen met het NHG een EURACT-meeting in Nederland, welke volledig was gewijd aan de kaderopleiding. Daarbij zijn met EURACT-leden uit heel Europa en met vertegenwoordigers van een aantal Nederlandse belanghebbende partner-organisaties ideeën uitgewisseld en bediscussieerd.

\section{Stand van zaken}

NHG en LHV hebben inmiddels de wens om tot een gecoördineerde kaderopleiding huisartsgeneeskunde te komen in hun beleidsplannen opgenomen. De opleidingen in de klinische deelgebieden Palliatieve zorg en Geestelijke Gezondheidszorg zijn intussen gestart. Ook de opleidingen Wetenschappelijke vorming en Kwaliteitszorg zijn de afgelopen jaren al een aantal keren georganiseerd. NHG en LHV zijn met het $1 \mathrm{OH}$ en de universitaire vakgroepen huisartsgeneeskunde overeengekomen om de uitvoering van de kaderopleidingen onder te brengen bij de verschillende vakgroepen huisartsgeneeskunde, met name die vakgroepen met specifieke expertise op het betreffende gebied. Dat biedt tevens de mogelijkheid om aan te sluiten bij de differentiaties binnen de huisartsopleidingen, zoals daar op dit moment aan wordt gewerkt. Het NHG ziet voor zichzelf een rol als inhoudelijk eindverantwoordelijke voor de eindtermen en voor de kwaliteit van de programma's. Daartoe heeft het coördinatiepunt een definitieve plaats gekregen binnen de afdeling Advies en Scholing van het NHG. Ook de al langer bestaande NHG supervisorenopleiding heeft inmiddels een plek gekregen binnen de kadertrainingen huisartsgeneeskunde, nu als kaderopleiding supervisie en teamcoaching. 


\section{Toekomst}

Kijkend naar de toekomst zou het goed zijn als voor de verdere ontwikkeling en uitvoering van de opleidingen "klinische deelgebieden" nauw samengewerkt wordt met de verschillende Expertgroepen die op dit moment in ontwikkeling zijn. Daarnaast dient werk te worden gemaakt van een liefst uniforme wijze van diplomering. De diploma's zouden bij voorkeur moeten aansluiten bij internationale ontwikkelingen, zoals bijvoorbeeld de Engellse "diploma-dlegree" of "master-degree".

De financiering voor het verder ontwikkelen van de cursussen, die nog niet klaar zijn zou een gezamenlijke inspanning moeten zijn van NHG, LHV, VWS, ZN en wellicht fondsen, zoals bijvoorbeeld het Astmafonds, de Hartstichting, de Maag Darm Leverstichting en het Diabetes Fonds Nederland.

Tenslotte is het van groot belang dat er formaties worden gecreëerd binnen de districten om huisartsen die deze kaderopleiding hebben gevolgd een rol laten spelen binnen de in Kwaliteit op Koers geformuleerde kwaliteitsteams. Voor een deel zijn deze formaties all beschikbaar en zijn er ook functionarissen werkzaam. Deze functionarissen zijn natuurlijk bij uitstek kandidaten om een of meer van de kaderopleidingen te volgen.

Anderzijds biedt de nieuwe honeringssystematiek zoals die is voorgesteld door de commissie Tabaksblat goede mogelijkheden voor nieuwe kaderfuncties, omdat de kosten voor kwal iteitsfunctionarissen (en dus ook hun opleiding) via de locale kostencomponent voor vergoeding in aanmerking komen. Zo kunnen daartoe gemotiveerde huisartsen in deeltijd doorstromen in de zo belangrijke kaderfuncties binnen het kwaliteitsbeleid van de beroepsgroep.

Het zou dan ook goed zijn als overheid en zorgverzekeraars werk maken van het invoeren van de door de commissie Tabaksblat geadviseerde financieringssystematiek, omdat dat veel betere waarborgen biedt voor het in stand houden van een professionele ondersteuningsstructuur. Mocht deze de komende jaren tot stand komen, dan is het voorwerk gedaan en staat er goed opgeleid kader 
klaar om die belangrijke functies op zich te nemen. En dat is dan mede te danken aan de vooruitziende blik van degenen die daar al 10 jaar geleden mee zijn gestart. Aan de visie en de vasthoudendheid van de pioniers. Een van de belangrijkste van hen was Harry Crebolder. Met dank.

Drs. MLF Klomp, huisarts, is lid van het Dagelijks Bestuur van het NHG. Dr. T. Van Essen, huisarts, is Voorzitter van het Bestuur van het NHG. 


\section{De kwaliteitskant van Harry}

Richard Grol.

Ik smaak het bijzondere genoegen Harry al bijna net zo lang te kennen als ik zelf binnen de huisartsgeneeskunde werk en dat is dit jaar 25 jaar. Eerst vanwege zijn proefschriftproject in Nijmegen en als leidende huisarts in het gezondheidscentrum te Venlo, waar wij onze eerste experimenten met kwaliteitstoetsing deden. Later als collega in Maastricht, een periode waaraan ik zeer goede herinneringen bewaar. In het bijzonder aan het huis van Emma en Harry dat altijd openstond voor een verdwaalde reiziger als ik. Als hoogleraar Kwaliteit van Zorg ligt het voor de hand dat ik de 'kwaliteitskant' van Harry zal belichten. En dan niet in de eerste plaats zijn persoonlijke kwaliteitskant, - in veel opzichten is hij uiteraard vleesgeworden kwaliteit - maar met name zijn bijdrage aan het verbeteren van de kwaliteit van de huisartsgeneeskunde. Om dit goed te doen wil ik eerst de vraag stellen hoe in de huisartsgeneeskunde (en daarbuiten) de kwaliteit van de patiëntenzorg het beste op een zo hoog mogelijk peil gebracht kan worden en daarin Harry's plaats toelichten. In de wereld van de kwaliteit zijn wij gewend de kwaliteit van handelen te toetsen, liefst op een zo constructief mogelijke manier.

Op het terrein van het verbeteren van de kwaliteit van de patiëntenzorg bestaan uiteenlopende gedachten en benaderingen. $\mathrm{Er}$ zijn bijvoorbeeld mensen - met name uit de wetenschappelijke hoek die denken dat als huisartsen maar voldoende geïnformeerd worden via publicaties, NHG-richtlijnen of andere bronnen - over het beste bewijs achter bepaald handelen, de zorg voor patiënten hierdoor zal verbeteren. Wij weten inmiddels dat onderzoeksresultaten vaak bias bevatten, dat richtiijnen niet perfect zijn en snel verouderen en dat richtlijnen bovendien in de praktijk maar ten dele worden toegepast. Er zijn anderen, met name uit de hoek van de politiek en verzekeraars, die hun heil veel meer zoeken in het verzamelen van gegevens over het handelen van huisartsen, daarover feedback willen geven, deze gegevens het liefst zouden willen publiceren in het kader van 'transparantie' en 's nachts dromen van het koppelen van beloningen of sancties aan het al dan niet voldoen aan bepaalde afspraken of 
verwachtingen. Helaas moeten wij op grond van bestaand onderzoek vast stellen dat de feitelijke zorg vaak niet goed valide gemeten kan worden, dat dergelijke feedback vaak geen invloed op het handelen van huisartsen heeft en dat meestal niemand zich iets aan lijkt te trekken van openbaar gepresenteerde gegevens.

Harry heeft zich in zijn werkleven vooral met twee, nogal verschillende benaderingen van kwaliteitsverbetering bezig gehouden: een vooral individueel en professioneel gericht, de ander vooral multi-professioneel en organisatorisch gericht. I zal op beide kort ingaan.

De eerste is de professionele educatie en ontwikkeling; deze heeft altijd Harry's bijzondere interesse gehad. Onderwijs, opleiding, nascholing, professionalisering lopen als rode draad door zijn carrière. $E r$ is inmiddels een overdaad aan onderzoek dat aantoont dat klassieke vormen van scholing -voor de klas, lezingen, cursussen en conferenties- geen invloed hebben op de feitelijke patiëntenzorg (Grol et al. Implementatie 2001). Dit besef was in de problem-based medische opleiding in Maastricht uiteraard allang doorgedrongen. Nieuwe benaderingen in de nascholing, getooid met fraaie labels als continuous professional development, portfolio learning, selfinstructional learning en professional revalidation, gaan uit van vergelijkbare assumpties: leren verloopt het meest effectief als het gebaseerd wordt op (objectief vastgestelde) leerbehoeften en problemen in de dagelijkse praktijk en op een actieve deelname van de arts om er iets aan te doen. Hoewel dit soort modieuze benaderingen een hoge mate van facevalidity en aantrekkelijkheid bezitten, is er nog nauwelijks onderzoek verricht naar hun effectiviteit en naar de vraag of de extra investeringen in dit soort professionele educatie echt de moeite waard zijn. Goed uitvoeren van zulke benaderingen vereist dat men valide toetsen en systemen heeft om de competentie en kwaliteit van het handelen te kunnen bepalen. Zulke toetsen en systemen zijn er nog onvoldoende en toepassing vereist ook een enorme cultuuromslag voor de meeste artsen: '.... we need a culture that allows doctors to express fears, doubts and vulnerabilities', aldus de editor van de BMJ. In zijn carrière, onder meer 
in het basiscurriculum in Maastricht en als lid van EURACT, heeft Harry een belangrijke bijdrage geleverd aan het denken over dergelijke nieuwe benaderingen van professionele ontwikkeling. Hij heeft nieuwe onderwijsvormen bedacht, heeft nieuwe modellen voor een kaderopleiding van huisartsen uitgezet en is initiërend geweest in het beschrijven van het profiel van de 'kwalliteitsdokter' in Europees verband. De balans op dit terrein opmakend valt hier vooral een belangrijke "maatschappelijke output' op.

De andere benadering van kwaliteitsverbetering waarop Harry zich heeft gericht is er een die verbetering van de patiëntenzorg niet in de eerste plaats als een zaak van professionals ziet, maar vooral als een zaak van het beter organiseren en 'managen' van de zorg. Het systeem moet op de schop wil er verbetering kunnen ontstaan. Een betere samenwerking, betere overdracht van informatie, verandering van de cultuur in de praktijk, effectiever leiderschap, ICT-

ondersteuning, en vooral ook het efficiënter organiseren van zorgprocessen vormen de kern van een betere zorg. Interesse voor dit gebied voert natuurlijk logisch voort uit de jarenlange ervaringen in het Gezondheidscentrum Withuis. Ook de huidige minister Borst heeft inmiddels het managementlicht gezien na een aantal succesvolle 'bussiness redesign projecten'. Toch is ook de kennis over de effectiviteit van deze benadering nog heel lacunair. Gecontroleerde studies zijn er nauwelijks en de studies die er zijn in de eerste lijn tonen een beperkte effectiviteit. Het is in dit licht interessant om na te gaan hoe een van Harry's hobbies, de transmurale, multidisciplinaire samenwerking het in de literatuur doet. De literatuur op dit gebied is niet eenduidig (Grol et al. Implementatie 2001). Ze valt uiteen in studies naar: a. de aanpassing van taken en verantwoordelijkheden van arts naar een andere medewerker (nurse of assistente). Overdracht van preventieve taken bleek in 4 studies tot ruim $30 \%$ verbetering te leiden. Echter, een review met 6 studies waarin taken aan verpleegkundigen werden overgedragen toonde geen enkel significant effect. b. disease management, integrated care management, etc: hiervoor ontbreken nog systematische literatuuroverzichten; c. verbeterde samenwerking tussen disciplines: op dit punt zijn er verschillende reviews beschikbaar, maar de 
resultaten zijn niet eenduidig. Hearn analyseerde 18 studies naar het effect van gespecialiseerde multi-disciplinaire teams voor patiënten met kanker, waarvan 5 gecontroleerde studies. Satisfactie, pijn of ziekenhuisopnames bleven gelijk of verbeterden wat in 4 van de 5 studies. Een analyse van 22 studies naar de inzet van multiprofessionele teams in de ambulante geriatrische zorg toonde effecten in hooguit een derde van de studies. Echter $r_{11}$ een review van 7 studies naar de effecten van CVA-ketenzorg liet in 6 studies een significant effect op het aantal dagen in het ziekenhuis en de kosten van de zorg zien.

Kortom, een veld dat nog verder geëxploreerd dient te worden en waar goed en relevant onderzoek verricht moet worden.

Hoe kunnen wij Harry's werk hierin positioneren. Een snelle search in PubMed levert onder de naam Crebolder 48 hits op die de internationale publicaties van Harry sinds 1969 weergeven. Na een verrassende eerste publicatie in het NTVG in 1969 onder de titel 'A case of childbirth via de anus' - duidelijk een pre-transmurale oprisping - worden de publicaties vooral gekenmerkt door een grote belangstelling voor chronisch zieken en voor het verbeteren van de kwaliteit van zorg via een betere coördinatie en een betere samenwerking tussen disciplines over de muren van de zorg heen. Onderwerpen als beroerte, valpreventie en mobiliteit van ouderen, kanker, terminale zorg, zwakzinnigheid, etc. komen voor in het lijstje van onderzoeken, promotieonderzoeken meestal, die mede door Harry zijn begeleid. Een belangrijke bijdrage aan de kennisontwikkeling en kwaliteitsverbetering in de transmurale zorg is zeker het review in de BMJ over 'comprehensive home care for cancer patients' (Smeenk et al 1998). Uit 9 gecontroleerde studies bleek dat de effecten hiervan nog niet zonder meer vast staan, alhoewel er hier en daar positieve effecten worden gevonden wat betreft de satisfactie en de kwallteit van leven van patiënten en regelmatige multidisciplinaire besprekingen een positieve invloed op de uitkomsten van de studies leken te hebben. Kortom, op dit punt is een plaatsje in de geschiedenis verworven en heeft Harry een duidelijke wetenschappelijke bijdrage aan de kwaliteitsontwikkeling geleverd. 
Een plaats in de geschiedenis van WOK heeft hij eveneens verworven. De Werkgroep Onderzoek Kwaliteit, een samenwerking tussen de KUN en de UM, bestaat nu bijna 12 jaar en heeft zich in die periode ontwikkeld van een persoonlijk initiatief van enkele enthousiastelingen in twee groepen huisartsgeneeskunde tot een groot samenwerkingsverband met een nationale en internationale uitstraling, waar zo'n 80 mensen werken. Vanaf het allereerste begin was Harry actief betrokken bij inhoud en bestuur van dit samenwerkingsverband. Voortdurend heeft hij zich sterk gemaakt voor een nauwe samenwerking tussen de twee universiteiten en gehamerd op het belang daarvan. Regelmatig had ik hem knorrig aan de lijn als er weer eens helemaal langs elkaar heen werd gewerkt. Het moet iets te maken hebben met zijn historie van werken aan beide universiteiten en zijn historie van praktiseren precies in het midden in venlo dat hij deze zuid-oost as van de kwaliteit zo wilde benadrukken. Vooral de laatste jaren heeft hij zich als voorzitter van de Capaciteitsgroep Huisartsgeneeskunde en van de nieuwe BZe VII van het az $M$ ingespannen voor een goede inbedding en bemensing van de WOK groep in Maastricht. Dat is een belangrijke steun geweest die de WOK in de toekomst moeilijk zal kunnen missen.

Harry, de toetsing is verricht, de balans is opgemaakt, de feedback is positief. Er is veel dat wij zullen missen als jij je binnenkort aan belangrijker zaken gaat wijden. Maar de WOK zal in jouw geest doorgaan; jouw geheven vinger zal ons op het rechte pad houden. veel dank, Harry, en altijd welkom!!

Prof.dr. R. Grol is hoogleraar Kwaliteit van Zorg aan de KUN en hoogleraar Kwaliteitsbevordering en -bewaking in de Huisartsgeneeskunde aan de UM. 


\section{Multidisciplinair onderzoek in de huisartsgeneeskunde; een contradictio in terminis?}

Onno van Schayck.

De laatste decennia zien we internationaal een steeds sterker wordende verschuiving optreden van monodisciplinair onderzoek naar multidisciplinair onderzoek. Ook in Nederland zien we deze trend. De overtuiging dat niet vanuit één discipline baanbrekend onderzoek gedaan kan worden, wordt sterk ondersteund door de KNAW en door belangrijke subsidieverleners zoals NWO en collectebusfondsen. Dit besef heeft (mede) geleid tot de vorming van (universitaire) onderzoeksinstituten en onderzoeksscholen waarin het onderzoek thematisch ondergebracht is. Het universitair onderzoek wordt dus steeds minder aangestuurd vanuit de traditionele (monodisciplinaire) vakgroepen, maar steeds meer vanuit de multidisciplinaire onderzoeksinstituten. Aan deze trend ligt de overtuiging ten grondslag dat doorbraken in onderzoek vooral bewerkstelligd kunnen worden door samen te werken en door gebruik te maken van expertise van verschillende disciplines. Zo kan een bepaalde ontwikkeling in een discipline toegepast worden in een ander aanpalend vakgebied, waardoor duidelijk vooruitgang geboekt kan worden. De voorbeelden zijn legio, ook in de geneeskunde. De samenwerking tussen bijv. de disciplines cardiologie, epidemiologie en genetica heeft geleid tot belangrijke genetische en epidemiologische inzichten over de vroege ontwikkeling van hart- en vaatziekten. Deze ontwikkelingen zijn zo evident dat niemand deze nog zal ontkennen. Enkele decennia terug was deze samenwerking echter minder voor de hand liggend. De Universiteit Maastricht (toen nog RL) heeft echter al vanaf haar oprichting gekozen voor thematisch georiënteerd onderzoek. Onderzoek werd ondergebracht in multidisciplinaire thema"s, die later werden uitgebouwd tot onderzoeksinstituten. In deze ontwikkeling liep de UM voor op de meeste universiteiten in Nederland.

Eenzelfde ontwikkeling zien we ook bij het extramuraal georiënteerde onderzoek, bijwoorbeeld bij het huisartsgeneeskundig onderzoek. 
Huisartsgeneeskundig onderzoek heeft zich in de afgelopen jaren sterk ontwikkeld, vooral in samenwerking met specialistische disciplines en met belangrijke aanpalende disciplines zoals statistiek, medische informatica en epidemiologie. Er zijn talloze voorbeelden te noemen. Diagnostische tests die veelal ontwikkeld werden in de kliniek dienden uitgetest en onderzocht te worden in de huisartssetting, niet alleen omdat de ernst van ziekte in een eerstelijns populatie doorgaans anders is, maar ook omdat de populatie waarin de test onderzocht wordt heel anders is (waardoor het onderscheidend vermogen van een dergelijke test per definitie verschillend is). Deze ontwikkeling was een belangrijke stap voorwaarts voor het huisartsgeneeskundig onderzoek. Niemand zal ook tegen deze ontwikkelingen zijn, de voordelen zijn duidelijk. In de praktijk van alledag betekent deze ontwikkeling bijvoorbeeld dat bij een vakgroep Huisartsgeneeskunde niet alleen huisartsen onderzoek doen, maar ook steeds meer andere dissciplines. Waren dat in de jaren 70 hoofdzakelijk medisch sociologen en huisartsen, nu zien we een grote verscheidenheid aan disciplinnes. Op de Capaciteitsgroep Huisartsgeneeskunde van de Universiteit Maastricht werken momenteel van de ca. 150 medewerkers meer dan de helft in de Sectie Onderzoek, met veel verschillende achtergronden (huisartsen, basisartsen, epidemiologen, gezondheidswetenschappers, bewegingswetenschappers, sociologen, psychologen, etc.). Deze vakgroep is hiermee de grootste vakgroep Huisartsgeneeskunde in Nederland. Maar de vakgroep is niet alleen groot, maar ook bijzonder succesvol en productief, mede door de veelzijdige interactie die plaatsvindt tussen onderzoekers. Het onderzoek werd als excellent beoordeeld bij het laatste disciplineoordeel van de KNAW in 1998. De extramurale oriëntatie die de Faculteit Geneeskunde vanaf haar ontstaan gehad heeft is dus niet zonder gevolgen gebleven.

Ondanks deze positieve ontwikkelingen kunnen er ook kanttekeningen worden gemaakt.

Zo is er met de komst van multidisciplinair onderzoek bij sommigen een (groelende) zorg dat er minder ruimte is voor typisch huisartsgeneeskundig onderzoek. Vragen die voortkomen uit de 
praktijk van alledag krijgen mogelijk minder ruimte om onderzocht te worden, deels omdat de directe invloed van praktiserende huisartsen minder groot is op het onderzoek dat uitgevoerd wordt, deels omdat het soms niet eenvoudig is subsidie te verwerven voor de typisch huisartsgeneeskundige vraagstellingen. Recent heeft het Nederlands Huisarts Genootschap juist met het oog hierop een nieuw fonds opgericht, het zgn. Fonds Alledaagse Ziekten. De middelen zijn echter beperkt, waardoor alleen kleine projecten gehonoreerd kunnen worden. Het is belangrijk om oog te hebben voor deze ontwikkelingen en huisartsen de ruimte te geven en vooral te betrekken bij vraagstellingen voor extramuraal onderzoek.

Daarnaast is het de vraag wat typisch huisartsgeneeskundig onderzoek is. Betreft huisartsgeneeskundig onderzoek alleen het onderzoek dat het diagnostisch of therapeutisch handelen van de huisarts raakt of is het al het onderzoek dat gedaan wordt bij patiënten die niet onder behandeling van de specialist zijn? Die scheiding is niet zo simpel te maken, zeker met het wegvallen van de muren tussen de intra- en extramurale zorg. Deze muren hebben lang een wat artificiële scheiding in de zorg benadrukt en in stand gehouden. "Een patiënt die met vermoeidheidsklachten bij de huisarts komt" heeft zonder twijfel betrekking op huisartsgeneeskundig handelen. Is een daarop volgende cognitieve gedragstheraple uitgevoerd door de huisarts nu huisartsgeneeskundig handelen? En als deze door een eerstelijns psycholoog wordt uitgevoerd? Als vermoeidheid een van de belangrijkste ingangsklachten is bij huisartsgeneeskundige consulten dan is het belangrijk dat de huisarts in staat is een zinnige (en zo mogelijk evidence-based) behandeling aan te bieden. Zo zijn er vele voorbeelden te noemen. Is secundair preventief handelen nu wel of geen huisartsgeneeskunde? Waar anders dan de in de eerste lijn dienen ziekten in een vroeg stadium opgespoord te worden? Niet alle behandelingen in de eerste lijn hoeven allemaal door de huisarts (alleen) gedaan te worden. Praktijkverpleegkundigen en consulenten kunnen veel routinehandelingen overnemen en de taak van de huisarts daarmee ontlasten. Het vak huisartsgeneeskunde wordt steeds breder en dat is niet ten onrechte. Deze ontwikkeling moeten 
we ook niet tegenwerken. Als er specialisatie en differentiatie binnen (en zelfs tussen) huisartspraktijken ontstaat ("Voor hartlongproblemen, linksaf. Voor problemen aan het bewegingsapparaat, rechtdoor", etc.), is dan de huisartsgeneeskunde in feite geen multidisciplinaire geneeskunde aan het worden? Op zijn minst kun je stellen dat huisartsgeneeskunde versus multidisciplinair geneeskunde (steeds meer) een schijntegenstelling is. Het multidisciplinaire onderzoeksinstituut voor de extramurale en transmurale gezondheidszorg (ExTra) van de Universiteit Maastricht is hierin "het vleesgeworden" voorbeeld. Immers, dit multidisciplinair instituut is ontstaan vanuit de capaciteitsgroep Huisartsgeneeskunde en deze capaciteitsgroep is nog steeds de "leverancier" van de meeste onderzoekscapaciteit van dit instituut. Momenteel werken echter 23 capaciteits groepen (waaronder vele die in het az $M$ gevestigd zijn), ieder vanuit een eigen discipline samen in het onderzoek van dit instituut. Met de komst van BZe VII waarin Huisartsgeneeskunde ook ten dele in de organisatie van het ziekenhuis is opgenomen wordt de samenwerking nog meer versterkt.

Harry Crebolder heeft als huisarts/onderzoeker deze ontwikkeling in de afgelopen periode van zeer dichtbij meegemaakt. Hij heeft vooral in de laatste jaren van zijn carrière als capaciteitsgroepvoorzitter het multidisciplinair onderzoek sterk ondersteund en een stimulerende rol hierbij gehad. Was er in het begin bezorgdheid (en tot op zekere hoogte argwaan) over multidisciplinair thematisch onderzoek, steeds meer ondersteunde hij deze ontwikkeling. Hij heeft hierdoor sterk bijgedragen aan de positieve groei die de huisartsgeneeskunde in Maastricht heeft doorgemaakt en aan wat de Capaciteitsgroep Huisartsgeneeskunde op dit moment is.

Prof. dr. O. van Schayck is directeur van het Onderzoeksinstituut ExTra aan de UM. 


\section{Harry als promotor}

Paul Stalenhoef.

Achter je

aan het zadel

de hand van vader

Vallen mag

weer opgestaan

Zoek de pedalen

kalm aan

Dan ontdek je

dat je zelf

zonder vaders hand

de bocht instuurt

Onbeholpen nog vastberaden dan

je fiets de baas

terug naar vader

Trots allebei:

Het is gelukt.

Toen hij aantrad werd zijn naam steevast uitgesproken met de klemtoon op de tweede lettergreep in plaats van op de eerste. Wie was hij? We wisten het nog niet en met enige scepsis werd hij bejegend. We wisten wel, dat hij een protégé was van de legendarische Frans Huygen. En als Frans iemand goed vond, dan was hij ook goed. Maar als je in de universitaire arena je opwachting maakt, heb je dat te bewijzen. Meedogenloos.

Harry deed dat met verve. Nieuwsgierig ging hij op tocht. Hij toonde zich betrokken en vooral bleek hij een huisarts te zijn in ons midden, die ons steeds weer deed voelen waar het allemaal om te doen was. Details waren details en mochten niet worden verward met de hoofdzaken. zö hebben wij hem leren kennen. zijn belangstelling 
beperkte zich niet tot je vorderingen in het wetenschappelijk métier, maar betrof ook een persoonlijke interesse in je wel en wee. "Thuis alles goed?" Gestaag werkte hij aan een imago van de leider, natuurlijk ook met vallen en opstaan.

Promotor, pro-motor, een motor vooral. Wie het voorrecht genoot door hem te worden begeleid, heeft kunnen ervaren, dat dat niet vrijblijvend is. Hij verwachtte veel en terecht.

Mijn eerste persoonlijke ervaringen met hem betrof een onderzoek in ons gezondheidscentrum, zo'n 12 jaar geleden. Gewapend met weinig ervaring met het opzetten en het uitwerken van een onderzoek bracht hij ons huisartsen, mensen van de praktijk, wel eens in verwarring. Er moest iets tot stand komen, iets groots tot stand komen. En als ik denk aan die tijd, zie ik hem vooral als een inspirator en een enorme doorzetter, die het vermogen had ons te leren ontdekken, dat er meer kwaliteiten in ons schoolden, dan wij tot dan toe voor mogelijk hadden gehouden. Niet dat we dat altijd als prettig hebben ervaren. Want op overduidelijke wijze wist hij ons steeds aan gemaakte afspraken te herinneren. Uiteindelijk kwam het dan toch goed. We voelden in hem soms wel eens een vader, die ons telkens weer vroeg of we ons huiswerk wel af hadden en of het op school wel goed ging. Daartussendoor altijd de humor, een kwinkslag, die alles relativeerde.

De productie van het boekje Thuiszorg, uitgegeven door Bunge in 1989 was ook zo"n tour de force. Harry was benaderd door uitgeverij Bunge om in de reeks Practicum huisartsgeneeskunde een boekje over thuiszorg samen te stellen. Hij nam dat energiek ter hand. Wij volgden. Het boekje kwam er, jammer genoeg net na het overlijden van They Lemmens. Van de opbrengsten hebben we nog een keer vorstelijk gegeten in Kasteel Wittem, en aan They gedacht.

Mijn persoonlijke herinneringen met Harry als promotor dateren van 28 april 1993. Begonnen na veel twijfels aan een promotieonderzoek over vallen van ouderen, één van zijn interesses, wist hij mij te overtuigen dat het goed zou zijn als ik dit werk ter hand zou nemen. Gezeten in mijn tuin, zei hij, mijn twijfels proevend: "Doe het maar. Het is een verrijking voor je. En ach, als het mislukt, dan mislukt het 
maar. Maar dan heb je het in ieder geval geprobeerd". Hij gaf mij zijn vertrouwen en dat is één van de belangrijkste kenmerken van een leider.

En zo ging ik dan op weg in een avontuur, dat een promotieonderzoek heet. De besprekingen over de vorderingen van het onderzoek waren vaak 's avonds bij hem thuis. Emma zorgde dan goed voor ons. Het waren boeiende avonden. $\mathrm{k}$ vertrok weer met meer moed dan ik was gekomen. Maar wel, hoe kan dat ook anders bij Harry, opgezadeld met nieuwe impulsen en opdrachten. "Doorgaan" was zijn motief. Wat ik in die jaren erna met hem beleefd heb is maar onder éen noemer samen te brengen: vriendschap. Met een bewonderenswaardige inzet en ijver, gaf hij een coaching, die verkwikkend was. Stap voor stap werden de bakens uitgezet. Harry kon met je mee huilen als je manuscript door een tijdschrift werd afgewezen en met je lachen als het wel was gelukt.

Dat hij vervolgens op de meest bizarre tijden, zoals zondags 's avonds laat opbelde of je dit of dat wel had geregeld, gaf mij wel eens enige wrevel, maar oak bewondering. Zo zit Harry in mekaar: ook een boer vergeet op zondag zijn koeien niet, dacht ik dan.

De uitspraken van Harry stemden mij ook tot nadenken. Geliefkoosd was zijn citaat van Sir Winston Churchill: "If you want something, ask a busy man". Of, en ik weet niet of dat ook een uitspraak van Churchill was: "It has no use to bring the horses to the river, if they don't want to drink". En zo nog meer uitspraken, die zijn Angelsaksische interesse verraden.

Dan breekt het moment aan dat je daar staat, voor de verdediging van je proefschrift. Het ultieme moment is natuurlijk als je de bul krijgt overhandigd van je promotor. Maar de toespraak erna herinner ik mij ook als een welgemeende en warme loftrompet. Alsof ik dat allemaal alléén had gepresteerd. Ik wist op dat moment ook donders goed, dat het product, dat een proefschrift heet, alleen maar tot stand heeft kunnen komen dankzij de inspanningen van velen, de promotor voorop.

Je moet niet denken dat hij je daarna loslaat. Welnee, er liggen zoveel kansen en taken. Hij noemt je onverdroten een expert op het terrein 
waarop je de doctorstitel hebt behaald. "Begint het nou weer?"dacht ik wel eens. Hij zei dan zonder blikken of blozen: "Je moet actief blijven, anders sijpelt je expertise weg..." waarbij ik me afvroeg of het wel eens bij hem opkwam of ik misschien niet onder dat juk uit wilde, omdat ik de praktijk al op mijn schouders voelde. Maar hij had gelijk. Met enige spijt kon hij me vertellen, dat het toch doodzonde is, als een huisarts eenmaal gepromoveerd, zich vervolgens schielijk terugtrekt in zijn praktijk met alle zijn beslommeringen. "Zo komt de wereld niet verder", zag ik hem dan denken.

Wij promovendi hebben veel te danken aan deze onvermoeibare werker, met een hoog gehalte huisartsenbloed in zijn aderen en veel begrip heeft voor wat een praktijk van hen vraagt. Die weet, dat het hebben van een praktijk ook soms haaks staat op de verplichtingen die je hebt als facultaire medewerker. Hij liet dat merken door zo vaak te vragen: "Vertel eens, wat heb je vandaag voor interessante praktijkgevallen meegemaakt?" En in ieder voorbeeld ontdekte hij wel een uitdaging voor nadere exploratie, misschien zelfs een dissertatie. Verfrissend is dat en eerlijk gezegd ook vermoeiend. Omdat hij in jezelf het gevoel weet te wekken om zaken op te pakken, erover na te denken. "Never a dull moment" met Harry. Zijn bevlogenheid betreft ook vooral de geacademiseerde huisartsgeneeskunde als werkplaats en als broedplaats voor ideeën. Het stoort hem, dat de huisarts als een goedbedoelende doe-hetzelver zelf moet zorgen voor zijn organisatie in tegenstelling tot een specialist, die in een academisch ziekenhuis werkt met een grote facilitaire dienst. En ik denk ook, dat hij de ondersteuning van praktiserende huisartsen op het gebied van management hiermee bedoelt. Kwaliteit van de huisartsgeneeskundige zorg kan worden verbeterd, als ook de infrastructuur verbetert, zo vat ik zijn devies maar even samen. Zijn inspanningen voor het tot stand komen van een nauwe samenwerking met het academisch ziekenhuis, uitmondend in de realisering van BZe VII, is zijn laatste grote klus. Je voelt aan hem, dat hij dat goed wil achter laten, zij het dat het bouwwerk nog hier en daar in steigers staat. Zorginnovatie moet beginnen vanaf de werkvloer. Dáár moeten de ideeën en de plannen 
vandaan komen, dáăr moeten de inspiratie en de krachten worden gebundeld.

En dan gaat zo'n man zomaar weg. Het zit er op. Ik kan mij Harry nog niet goed voorstellen achter de geraniums, in een rol, die ook Emma niet zal aanstaan.

Doe mij nog maar zo'n hoogleraar huisartsgeneeskunde: gedreven en bevlogen, een niet aflatende gangmaker van allerlei, teveel om op te noemen, initiatieven.

We hopen dat we in zijn opvolger veel van zijn eigenschappen en vriendschap mogen tegen komen.

Harry, het ga je goed. Zelf zou je zeggen: "Goede moed". En, je mag gerust zondagsavonds eens bellen, zomaar voor een babbel, over dit of dat, of over het vak, dat ons zo dierbaar is.

Dr. P. Stalenhoef, huisarts, werkzaam in het academisch Gezondheidscentrum "Van Kleef" in Maastricht. 


\section{H arry Crebolder}

Pater

Academicorum,

Tu

Emigrase

Ratio,

Age

Criticus

Academicus,

Declamator

Energeticus,

Major

intellector,

Communis

Universitatis te

Salutat!

Vale!

Patricius Smeets.

Dr. P. Smeets is huisarts in Maastricht. Hij promoveerde bij Harry Crebolder.

Gieschreven mede namens de promovendi. 


\section{Op geleide van Harry op zoek naar de horizon van de huisarts, de huisartsgeneeskunde en hemzelf}

Frans van der Horst.

Een terugblik op Harry's zoektocht naar de identiteit van de huisarts en de huisartsgeneeskunde laat zich niet gemakkelijk vangen onder één noemer. De keuze van een titel van dit verhaal ligt dan ook niet woor de hand. Ik heb al verschillende excercities achter de rug. variërend van 'Dokter Harry wordt niet goed', voortbordurend op de onderwijsconferentie "de dokter wordt niet goed' voor Nederlandse medische studenten aan de RL in 1979, tot 'Harry Crebolder van leerling-vlieger/piloot tot eskadronleider/verkeersleider".

Van de eerste optie heb ik afgezien omdat ik niet het risico wilde lopen dat de indruk bestaat dat Harry tot de 'burned-out' categorie behoort, temeer daar een ieder die hem kent weet dat eerder het tegendeel het geval is. Veroudering gaat bij hem tot nu toe geenszins samen met mindere energie, afgemeten aan zijn activiteiten. Dat Harry met pensioen gaat heeft een platvloerse reden: hij staat op het punt 65 jaar te worden. Daar kan zelfs hij niets aan doen .'het enige dat Harry niet in de hand heeft".

De tweede optie is komen te vervallen, omdat Harry een gerespecteerd verkeersleider geworden is van het vakgebied huisartsgeneeskunde. Afhankelijk van het thema dat ter sprake komt, gegeven de situatie die zich aandient, is hij ook nu nog in staat te kiezen voor de rol van leerlingvlieger. Zo hij dit doet, wordt dit ingegeven door de gedachte dat dit een snelle manier is om in een nieuw thema of nieuwe situatie ingevoerd te worden om daarna in het escadron 'gewoon' mee te vliegen of er 'desnoods' leiding aan te geven. Dit typeert zijn gevoel voor pragmatisme. Dit alles roept, als leidende gedachte achter dit verhaal, de vraag op hoe zijn horizon er in de loop van de tijd ging uitzien. In plaats van een veelwoud van gissingen op tafel te leggen, dan wel persoonlijke indrukken te uiten op basis van vele dagelijkse gebeurtenissen, leek het mij beter dit te beschrijven vanuit toetsbare empirische gegevens vervat in zijn curriculum vitae.

Aantekeningen in al dan niet virtuele dagboeken en notulen vormen de contextuele variabele. 
Een globale analyse van artikelen, voordrachten, proefschriften die (ook) zijn naam uitdragen, levert een gedifferentieerd beeld op, zij het dat het onderwerp 'cervicale uitstrijkjes' relatief vaak genoemd wordt, evenals het onderwerp 'medisch onderwijs'. Dit laatste kan begrepen worden vanuit zijn opdracht, het eerste vanuit de constatering dat hij in een productief netwerk vertoefde dat het onderwerp kennelijk uitgebuit heeft voor de publicatiemarkt. Toen ik zijn curriculum andermaal doornam, ontkwam ik niet aan de spontane uiting dat het Harry als huisdokter siert dat zijn eerste huisartsgeneeskundige publicatie betrekking heeft op de patiënt: in 1974 verscheen de publicatie 'Opvattingen van patiënten over huisartsen met wie de eigen huisarts samenwerkt'. Dit was kennelijk de eerste horizon die hij als huisarts koos ("de patiënt als basaal stekkie van de huisarts"). Al gauw verplaatste de horizon zich naar de in de zeventiger jaren in opkomst zijnde drie-eenheid huisarts, wijkverpleegkundige en maatschappelijk werker. Zij leken het antwoord te geven op het probleemaanbod in de eerstelijn. Enkele jaren later, in 1977, kwam ook de dokterassistente aan de kim.

Een cluster van publicaties over de drie-eenheid, de patiënt en de doktersassistente leidde tot een proefschrift en verdediging ervan in Nijmegen. Harry hoort daarmee tot de laatste 'founding fathers' van de huisartsgeneeskunde, die zich in de zeventiger jaren geprofileerd hebben vanuit de gezondheidscentra.

Het is dan ook niet verbazingwekkend dat de ingezette lijn van publicaties voortgezet wordt met andere eerste-lijners, zoals de diëtist en de fysiotherapeut. De verloskundige heeft het niet gehaald in de publicaties en bleef buiten de horizon. Het oudste medische beroep bleef helaas buiten de scope; het werd mogelijk ondergesneeuwd door nieuwe ontwikkelingen als richtlijnen, protocollen en toetsing. In 1985 kwam de medisch student in het vizier als co-assistent.

Na een artikel over obstipatie en farmacotherapie (niets is toevallig, zeg ik dan maar) kwam in 1985 ook de tweede lijn voor het eerst aan de orde. Ondertussen had Harry in 1983 in stilte (zoals het hoort) een pelgrimstocht naar McMasters gemaakt, hetgeen als een voorspeller 
gezien kon worden voor zijn intrede bij de UM. Mogelijk zijn daar de eerste schreden gezet voor zijn terugtrekking uit het Nijmeegse huisartseninstituut (....en met hem de Noord-Limburgse regio van huisartsen) en zijn groeiend engagement met het Maastrichtse.

Met de oratie in 1987 'Te leer in de eerste lijn' gaf hij zijn reflectie op ontwikkelingen in de eerste lijn, die hij zelf mede vorm en inhoud had gegeven. Daarmee werd zijn horizon geprofileerd en formeel uitgedragen. Met enthousiasme heeft hij zijn leeropdracht inzake de eerste lijn opgepakt. De door zijn voorgangers gelegde basis voor het academisch onderwijs heeft hij met voortvarendheid nog meer vorm en inhoud gegeven ('enthousiasme en voortvarendheid is Harry niet vreemd').

Zijn pragmatische aanpak gaf een nieuwe impuls aan de academisering van het veld en de netwerkrelaties die de duurzaamheid van dit proces hebben bestendigd. Deze ontwikkelingen sloten goed aan op de eerder ingezette verbreding en verdieping van het huisartsgeneeskundig onderzoek vanuit epidemiologisch perspectief. Dit begon met een wetenschappelijke scholing van jonge huisartsen, waarmee een bredere basis gelegd werd voor promotieonderzoek en het toekomstige onderzoekskader van de vakgroep.

Harry heeft zich ingezet om huisartsen te enthousiasmeren voor reflectie op de eigen praktijkvoering, ten behoeve van zichzelf als participant in de academische traditie, en ten behoeve van studenten en huisartsgeneeskundige onderzoekers. Een veelvoud van publicatieonderwerpen kwam hieruit voort en passeerden de revue. Niet alleen cervixuitstrijkjes, maar ook diabetes, mensen met kanker en astma, demente en vallende bejaarden en hartpatiënten trokken de aandacht van hem en huisartsonderzoekers. De horizon werd daarmee gedifferentieerder.

Ondertussen werd ook Harry ouder; hij memoreerde in 1994 het twintigjarig bestaan van zijn Withuis in Venlo. Hij had inmiddels voelsprieten ontwikkeld voor de traditionele horizon van de eerste 
lijn, de thuiszorg; tevens dook hij verder in de tweede lijn. De reikwijdte voor de thuiszorg kwam tot uitdrukking in multidisciplinaire richtlijnontwikkeling; de tweede lijnsoriëntatie kwam tot uitdrukking in het transmurale perspectief, dat veel later een structurele verankering kreeg in het azM bij de Behandel en Zorgeenheid VII. ('de huisarts heeft ook zijn stekkie in het ziekenhuis').

Inmiddels kreeg hij een nieuwe doelgroep in het vizier van de huisartsgeneeskunde: de verstandelijk gehandicapten. De deinstitutionalisering van de gehandicaptenzorg doet hen immers in grote getale behoren tot de patiëntenpopulatie van de huisarts. Daarnaast vormen de ouders, broers en zussen van de verstandelijk gehandicapten het mantelzorgcircuit. De mensen uit dit circuit doen zeer waarschijnlijk van tijd tot tijd een appel op de huisarts, dat mede begrepen kan worden van hun zware taak als mantelzorgers. Mantelzorg is tot nog toe in de literatuur van de huisarts een marginaal aandachtspunt wellicht omdat deze zorg de huisarts ook ontlast.

Een en ander kreeg en krijgt een structurele weerslag op de vorm en inhoud van huisartsgeneeskundige professie, de academisering van de professie en van de huisartspraktijk. Dit vinden we terug in de artikelen van Harry en collega's door alle jaren heen over het Maastrichtse curriculum.

In de loop der jaren is de inbreng vanuit de vakgroep een cruciaal onderdeel geworden in dit curriculum. Voor deze inbreng is de bijdrage van de huisartsen in het veld essentieel, hetgeen eveneens geldt voor het onderzoek.

Aan de andere kant heeft de inbreng van Harry er ook toe bijgedragen dat nieuwe ontwikkelingen binnen onderwijs en onderzoek het huisartsenberoep en de praktijkvoering nieuwe stimuli gegeven hebben en geven.

We mogen aannemen dat de huisartsgeneeskundige zorg op een kwalitatief hoger niveau gekomen is (deze uitspraak zal op geleide van Harry verder gefalsificeerd worden). De stimulerende kracht van 
Harry Crebolder als hoogleraar en voorzitter van de vakgroep was daarbij onmiskenbaar van betekenis.

Met dit laatste komen we op een thema dat in het voorgaande niet aan de orde is gekomen: de functie van voorzitter van de capaciteitsgroep; ook deze wordt vacant.

Harry was in eerste instantie in 1996 benoemd tot Coördinator van het huisartsgeneeskundig (officieel 'eerstelijns') onderwijs. Vier jaren later werd de leeropdracht gewijzigd in 'Huisartsgeneeskunde, in het bijzonder eerstelijns onderwijscoördinatie'. Dit bleek achteraf een gelukkig keuze omdat dit hem de mogelijkheid gaf het curriculum expliciet in het kader van (de ontwikkeling van) huisartsgeneeskunde te plaatsen. Tot het werkterrein behoorde immers het hele vakgebied, hetgeen de kans bood condities te scheppen die het mogelijk maakte het curriculum uit te bouwen naar en te verankeren in de systematische reflectie op de beroepsuitoefening, inclusief de praktijkvoering. Hiermee kwam naast onderwijs ook onderzoek in het huisartsgeneeskundige vizier van Harry. Daarmee lag de functie van voorzitter van de capaciteitsgroep meer voor de hand. Dit was destijds geen gemakkelijke taakstelling in een sterk in ontwikkeling zijnde capaciteitsgroep; het 'capaciteitsgroepbedje was dan ook geenszins uitgekristalliseerd.

In het begin was zijn sturend leiderschap zijn kracht en zijn zwakte. Zijn zwakte lag wellicht daarin dat hij moest wennen aan de cultuur van een professionele organisatie, waar onderling overleg en het bereiken van overeenstemming cruciaal was en is. Zijn kracht lag daarin dat hij besluiten kon nemen, vanuit de kennelijke opvatting dat het poldermodel niet zo ver reikt als de polder zelf ('Harry als zuiderling kent de horizon van de polder niet'). Harry was vanuit de dagelijkse praktijk van zijn handelen, uiteraard, geïnspireerd door een front-mentaliteit ('met Harry kan je wel de oorlog in'). Zijn sturend leiderschap is zijn kracht gebleven ('ik wil dat je dit vandaag regelt, gisteren mag ook'), maar in aanzienlijke mate opgegaan in situationeel leiderschap: afhankelijk van de situatie en de personen differentieerde hij naar steunen, sturen, begeleiden of delegeren (zijn karakteristieke afsluiting 'groet en goede moed' overstijgt deze 
typologie als persoonsgebonden uiting, kennelijk een residu van de Afrikaanse tijd). Opvallend is dat Harry nooit te oud was om (bij) te leren, alsmede anderen én zichzelf bij te sturen. De wijze waarop Harry zich van de toegewezen taak als voorzitter kweet, gaf hem op den duur dat brede draagvlak dat nodig was, om deze taak adequaat en met respect te kunnen vervullen. Aan zijn tot voor kort in nevelen gehulde opvolger de uitdaging zich op zijn beurt te profileren en een draagvlak te vinden.

De structuurnota geschreven ten behoeve van Harry's opvolger was tot het schrijven van deze verhandeling eveneens in nevelen gehuld. Dit geeft de vrijheid enkele domeinen te duiden die aandacht behoeven. Het vakgroepvoorzitterschap vervat in situationeel leiderschap vormt het eerste domein dat aandacht behoeft, teneinde de capaciteitskracht van de vakgroep en het veld als professioneel referentiekader maximaal te houden.

Het tweede domein betreft (aandacht voor) de identiteit van de huisarts in het sterk in beroering zijnde veld van huisartsgeneeskunde en gezondheidszorg. Daarbij doel ik in eerste instantie op de profilering van het vakgebied in een netwerk van nieuwe en veranderende professiegroepen in de eerste- en tweedelijn. Het beroepsbeeld in de gezondheidszorg is immers sterk in ontwikkeling: nieuwe beroepen ontstaan en beroepsdomeinen verschuiven. Dit geldt ook en vooral voor de huisarts ingebed in het zorgsysteem.

Deze veranderingen vragen zeker van de huisarts zelf een bezinning op de positie in de zorg. Onduidelijkheid over de te verwachten veranderingen in de organisatie en de financiering van de zorg maken deze bezinning niet gemakkelijk. Daarnaast dient geanticipeerd te worden op demografische-epidemiologische en sociaal-culturele ontwikkelingen; het laatste valt tot nog toe minimaal binnen de scope van de huisartsgeneeskunde.

Het derde domein sluit aan op het voorgaande en heeft te maken met de extra taakverzwaring van de huisarts, gekoppeld aan de academisering vanwege kwaliteitseisen aan onderwijs, onderzoek en patiëntenzorg. Geluiden uit het veld zijn tweeledig: enerzijds ervaren 
huisartsen de academisering als waardevol ook in termen van kwaliteitsverbetering, anderzijds ervaren zij in de knel te komen, omdat zij het nog drukker krijgen en geld moeten inleveren (vervanging kost meer geld dan wij ontvangen voor onze academische functie'). Daarmee dreigt de patiëntenzorg en loyaliteit aan de UM op den duur in de knel te komen.

Het vierde domein is vooral gekoppeld aan de tweede: de modernisering van de eerstelijn als onderdeel van de gezondheidszorg en samenleving is dusdanig dat ook de huisarts dreigt te vervreemden van de leefwereld van de patiënt. De huisarts loopt gevaar niet langer een schakel te zijn tussen de samenleving en het functionele systeem van de gezondheidszorg: hier lag en ligt de legitimering van zijn positie. De bureaucratisering en vertechnisering van huisartsgeneeskunde is immers nog volop aan de gang. Toetsing van deze ontwikkeling aan het perspectief van de patiënt en de geuite wens tot vraagsturing van de zorg vanuit de patiënt is een uitdaging die de huisarts niet uit de weg kan gaan. Het thema mantelzorg zou hier eveneens op zijn plaats zijn.

Mocht het zo zijn dat morgen besloten wordt tot flexibele pensionering van de huisarts en de wetenschappelijke bolwerkers aan de universiteit, dan acht ik het niet uitgesloten dat Harry zich alsnog aanmeldt voor een nieuw te creëren leerstoel huisartsgeneeskunde, in het bijzonder vraaggestuurde zorg. De burger dreigt immers als patient steeds meer in de verdrukking te komen door de toenemende rationaliteit van de gezondheidszorg (en de huisartsgeneeskunde!). De empowerment van de huisarts en de huisartsgeneeskunde is nog volop aan de gang. Deze kan pas dan geslaagd zijn wanneer deze ook en vooral ten dienste staat van de (te ontwikkelen empowerment van de) patiënt. Hier lag en ligt immers de ideologische verandering van de huisartgeneeskunde.

Daarmee zijn we terug bij de eerste horizon van Harry's eerste huisartsgeneeskundige publicatie. Als ik mij niet vergis zal Harry ook na zijn pensionering zich meer dan terloops bezighouden met dit thema. Mogelijk wordt dit op termijn zijn (intensieve laatste?) 
publicatieronde, al dan niet in de context van gezinsgeneeskunde. Dit thema staat immers nog steeds op zijn verlanglijstje.

Dr. F. van der Horst is Universitair Docent bij de Capaciteitsgroep Huisartsgeneeskunde van de UM. 


\section{Over leiderschap gesproken}

Ios op t Root.

The entrepreneur

Any of the 'dreamers who do'. Those who take hands on responsibility for creating innowation. The entrepreneur may be the creator or inventor but is always the dreamer who figures out how to turn an idea into a profitable reality. Pinchot

Een tiental jaar geleden kwam in de Capaciteitsgroep Huisartsgeneeskunde van de UM een discussie op gang over leiderschap. Kern van deze discussie was de vraag of de capaciteitsgroep moest worden geleid door een professionele manager of door een huisarts-hoogleraar. Zijdelings speelde nog de discussie over de omvang van de leiderschapstaken, toegespitst op de meer beheersmatige taken en de noodzakelijke coördinatietaken.

De discussie was niet beperkt tot de capaciteitsgroep, maar zij deed zich ook elders voor, o.a. op facultair niveau. Daar werd de discussie besiecht met de invoering van de Wet Modernisering Universitaire Bestuurshervorming. De decaan kreeg de eindverantwoordelijkheid en daarmee ook de nodige bevoegdheden. Er werd dus gekozen voor een bestuurder die afkomstig is uit de inhoudelijke staf. Dat patroon werd doorgetrokken naar de capaciteitsgroepen. De positie van de hoogleraar-voorzitter werd daarmee versterkt.

De discussie over aard en type leiderschap was geen exclusief universitaire aangelegenheid. Zij speelde zich ook elders af. Een sector die er bijvoorbeeld mee te maken $\mathrm{kreeg}$, was de museumwereld. Ook hier was er lange tijd discussie over het type directievoering. Zelfs aan enkele ministeries ging de kwestie niet voorbij, zoais bijvoorbeeld bij landbouw. Wie heeft de zeggenschap: landbouwingenieurs of managers, veelal met een juridische of economische achtergrond. ofschoon de discussie als keuzeprobleem voorbij is, geldt dat zeker niet voor de relevantie van de discussie wat betreft het type en de aard van het leiderschap en de daarvoor benodigde capaciteiten. Met het oog op het functioneren van vakgroepen valt hier best wat over 
te zeggen. Bovendien is het een belangrijke vraag hoe Harry Crebollder als voorzitter van de capaciteitsgroep Huisartsgeneeskunde van de UM hierin gefunctioneerd heeft. Of deze vraag ook wordt beantwoord laat ik graag aan u over.

\section{Stadia en typen leiderschap}

Een eerste vraag is of de aard van de opleiding en de discipline doorslaggevend zijn of dat andere factoren een rol spelen, zoals de wijze waarop het leiderschap wordt uitgeoefend. Historisch gezien valt hier wel wat over te zeggen. Bryman onderscheidt vier stadia in de wijze van leiderschapsuitoefening, stadia die hij plaatst in een historisch perspectief van de laatste halve eeuw.

- de 'trait approach' waarbij vooral persoonlijke kwaliteiten en kenmerken doorslaggevend werden geacht voor goed leiderschap;

- de 'style approach' waarbij de nadruk kwam te liggen op zichtbare gedragsaspecten;

- de 'contingency approach' waarbij de situatie bepalend is voor de opstelling van de leider, met name of deze zich meer relatie- of meer taakgericht moet opstellen;

- de "new leadership approach" die de voorgaande kwaliteiten en kenmerken probeert te integreren, maar waarbij tevens sprake is van een gerichte visie of 'mission'. (1)

Nieuw in de laatste fase is ook dat research naar leiderschapsfactoren zijn intrede doet en dat dit leidt tot diverse nieuwe concepten en beschrijvingen van leiderschapstypen. Maar een echt antwoord of de man of vrouw aan de top een inhoudelijk deskundige moet zijn op managementgebied of op het gebied dat de organisatie vertegenwoordigt, in ons geval huisartsgeneeskunde dus, of op beide gebieden, wordt niet gegeven.

Welk type dan succesvol is, blijkt vooral ook af te hangen van wat er moet gebeuren in een organisatie. De positie alleen is niet voldoende voor goed leiderschap. Het gaat ook om de nodige vaardigheden en om een voor de functie juiste attitude. Bovendien zijn bepaalde kwaliteiten en kenmerken nodig om de meestal diverse en specifieke leiderschapstaken in een organisatie goed te vervullen. 
Als het gaat om leiderschapkenmerken, is het verhelderend om uit te gaan van twee uitersten, zoals uitgewerkt door Kotter. (2) Enerzijds is er het type dat meer strategisch en beleidsmatig is gericht en als ondernemer optreedt, anderzijds is er een type dat meer managementachtige en beheerskenmerken heeft. In het eerste geval spreekt Kotter over leiderschap, in het tweede geval over management.

\section{Management en leiderschap}

Managementgericht leiderschap heeft te maken met het hier en nu functioneren van organisaties. Diepgaander zaken die te maken hebben met (strategische) doelen en de eigen identiteit van een groep of organisatie krijgen hierbij veel minder aandacht. Leiders die dat wel doen, de ondernemers, leggen meer nadruk op de wijze waarop mensen in organisaties denken met betrekking tot wat wenselijk, mogelijk en noodzakelijk is om uit te voeren, stelt naast Kotter, een andere auteur, Zaleznik. (3) Je zou ook kunnen spreken van een gerichtheid meer op interne versus een gerichtheid meer op externe doelen.

De hiervoor genoemde discussie staat niet los van het hier genoemde onderscheid. Opleiding en discipline spelen een rol, maar ook de wijze waarop een leider de uitoefening van het leiderschap opvat.

Bovendien is van belang welk type leiderschap de organisatie nodig heeft. Misschien wel beide.

Kotter, die uitgebreid onderzoek heeft gedaan naar het hier genoemde onderscheid, stelt dat leiderschap te maken heeft met een proces waarin mensen de weg gewezen wordt en hen te mobiliseren voor ideeën en opvattingen die zij als de hunne ervaren. Leiderschap is nodig om een organisatie tot bloei te brengen. Management heeft te maken met het leiden van een groep van mensen en een organisatie in meer formele zin. Kotter maakt een duidelijk onderscheid tussen leiderschap aan de ene en management aan de andere kant. De manager houdt zich bezig met formele structuren, terwijl leiderschap meer in relatie moet worden gezien tot informele netwerken. (2) Kortom, de leider is verantwoordelijk voor de conceptuele aspecten, de manager voor de procedurele en structurele aspecten. 
Leiderschap en management houden zich beide bezig met het plannen van activiteiten, met het ontwikkelen vaneen structuur om de geplande doeleinden te bereiken, met het proces van uitvoering, met resultaten en met terugkoppeling.

\section{Enkele kenmerken}

Kotter deed zijn onderzoek bij een groot aantal bedrijven. Hij ging daarbij na hoe het succes van bedrijven te maken had met bepaalde leiderschap- en managementstijlen en -kwaliteiten. Dat bracht aan het licht dat er een onderscheid is tussen leiderschap en management met de bij iedere kwalificatie horende kenmerken. Karakteristiek voor de leider is dat hij richtingbepalend is, een visie ontwikkelt, de neuzen van de medewerkers in dezelfde richting zet, medewerkers inspireert en motiveert en nieuwe uitdagingen met hen alangaat. Leiderschap is ondernemerschap. "Een ondernemer is lemand die iets wil, die een idee heeft om in de praktijk te brengen en die daar op praktische wijze aan werkt. (...). lemand die gedreven is, iemand die een obsessie heeft met een (...) idee (...). Een ondernemer heeft een visie op wat hij of zij zou willen bereiken". (4) Voor een kennisorganisatie is het van belang dat de betreffende persoon vakinhoudelijk deskundig is.

Voor de manager is vooral kenmerkend dat deze zorg draagt voor een goede planning en begroting in dit proces, dat hij structuren ontwikkelt en zorg draagt voor de bemensing. Hij bewaakt de voortgangsprocessen, pakt de zich voordoende problemen aan, kortom hij ordent het project of de organisatie en maakt die voorspelbaar. Zonder dat zou er sprake zijn chaos. (2) "Managers zijn mensen die leiding geven, die weten hoe ze anderen an het werk moeten zetten en hoe ze anderen daartoe moeten kiezen". (4)

\section{Een onafscheidelijk paar}

Kotter ontdekte ook dat leiderschap en management bij elkaar horen en beide nodig zijn voor het goed functioneren van een organisatie. Maar, als er te veel nadruk ligt op het management bij een zwak 
leiderschap, bestaat het gevaar dat een bedrijf of organisatie te weinig innovatief is en onvoldoende inspeelt op maatschappelijke weranderingen. Omgekeerd kan er bij een zwak management en een sterk leiderschap sprake zijn van grote idealen die uiteindelijk leiden tot niets en van beloftes, verwachtingen en afspraken die niet worden waargemaakt. Een geïsoleerd, sterk leiderschap is ondermijnend voor de groep of organisatie, maar een te krachtig management tempert het enthousiasme, de motivatie en de werkvreugde.

Leiderschap dat goede ideeën voortbrengt anticipeert op maatschappelijke ontwikkellingen en loopt voorop bij nieuwe ontwikkelingen. Goed leiderschap betekent ook dat doorzettingsvermogen nodig is en dat obstakels moeten worden aangepakt. Dat werkt echter weer alleen als aan de managementkant de uitgezette lijn wordt vastgehouden.

Goede communicatieve eigenschappen zijn essentieel voor een vruchtbaar leiderschap. Communicatie is ook een belangrijk managementaspect, maar dan meer gericht op procedures en structuren en, afhankelijk van de organisatie, in hiërarchische zin. Voortvarendheid is een belangrijke eigenschap voor leiderschap. Daarnaast gaat het om een grote intrinsieke gemotiveerdheid en het kunnen overzien van vaak complexe processen over een groot aantal jaren heen. Dat vereist intelligentie en een behoorlijk niveau van mentale, emotionele en fysieke kracht en gezondheid. Wil een leider op termijn succesvol zijn, dan is tevens integriteit een essentieel kenmerk. Een brede algemene kennis en ontwikkeling is onontbeerlijk. (2)

\section{De succesvolle leider: een vat vol tegenstrijdigheden}

Collins die een onderzoekinstituut leidt op het gebied van management, ontdekte dat succesvolle leiders en topmanagers niet altijd mensen zijn die volgens de gangbare opvattingen en cultuur reuzen van leiders of inspirerende persoonlijkheden zijn. Meestal niet zelfs. Succesvolle leiders, dat wil zeggen leiders die hun onderneming gedurende een lange periode, zo niet blijvend, naar de top weten te brengen, lijken vaak vaten vol tegenstrijdigheden te zijn, bescheiden 
als persoon, maar vastberaden als bestuurder en met een ijzeren wil, timide maar ook keihard, verlegen en tegelijk moedig en onbevreesd. Stoïcijnse vastberadenheid en uitzonderlijke wilskracht gaan samen met een gebrek aan uiterlijkheden en pretenties.

Goede leiders, in de indeling van Collins de zogenaamde Niveau 5 leiders, doen wat zij moeten doen, ononopvallend, vasthoudend en simpel. Het eigen ego is ondergeschikt aan het doel. Goede managers hebben het niet over hun eigen rol! Het belang van de organisatie staat voorop, niet het eigenbelang. Als een succesvolle onderneming of organisatie na het vertrek van de topman instort, lijkt dit het genie van de betreffende persoon te bewijzen. Maar in wezen is dat juist niet het geval.

Goede leiders denken conceptueel en zij zijn in staat steeds en ook tijdig met nieuwe initiatieven te komen die aansluiten bij de ingezette lijn. Zij zijn de organisatie en het daarbij behorende maatschappelijke veld continu een stap vooruit. Zij kijken uit het raam, niet in de spiegel. Zij houden ontwikkelingen bij en spelen er tijdig op in.

Collins vat dit samen in het Yin en Yang model van Niveau 5. (5) Zie figuur 1.

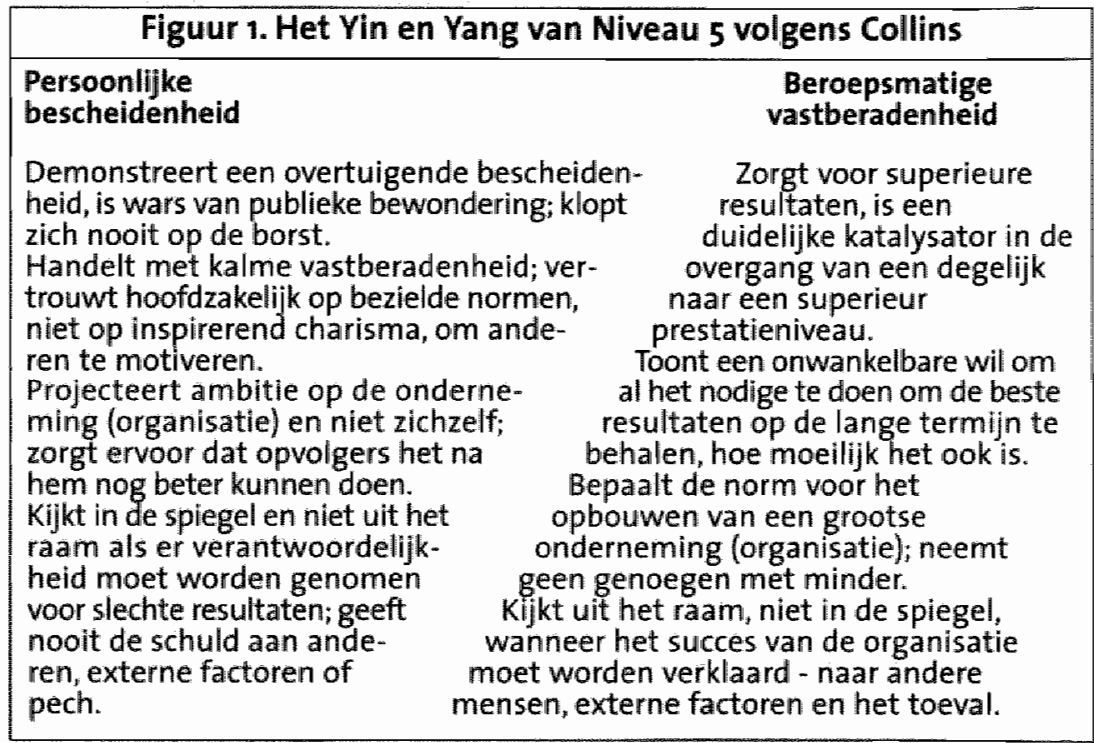


Goede leiders vinden visie en strategie belangrijk, maar zij achten mensen nog veel hoger. Belangrijk is dat de juiste mensen met de juiste capaciteiten worden aangesteld op de juiste plekken. Maar, zoals Drucker zegt, elke personeelsbeslissing blijft een gok. (6) Overigens schromen zij niet om in deze zin sanerend op te treden. zij blijken te kunnen zorgen dat een cultuur van discipline ontstaat, niet opgelegd of hiërarchisch, maar op basis van intrinsieke motivatie van de medewerkers. Collins onderscheidt drie soorten discipline: mensen met discipline, gedisciplineerd denken en gedisciplineerd handelen. Mensen met discipline hebben geen hiërarchie nodig. Ook niet nodig zijn bureaucratie en overmatige controle. (5)

\section{De omvang van de formatie}

Interessant is de vraag naar de omvang in formatie van de management- en leiderschapformatie. Deze vraag is mede van belang omdat organisaties, zeker de universitaire, geneigd zijn aan de genoemde functies maar beperkt formatie toe te kennen.

Uit het onderzoek van Kotter blijkt dat managementtaken bij de door hem onderzochte bedrijven 10 tot $20 \%$ van de beschikbare formatie in beslag nemen. Dit heeft dan betrekking op het lijn-en stafmanagement gezamenlijk. De lijnmanager is dan vooral verantwoordelijk voor de planning, de organisatie van de uitvoering en de controle en evaluatie hiervan. Stafmanagers zijn verantwoordelijk voor specifieke taken als bijvoorbeeld de budgettering. Uit het onderzoek kwam ook naar voren dat de leiderschapsformatie niet zo eenduidig is aan te geven met een percentage van de totale formatie. De omvang ervan blijkt sterk samen te hangen met het type organisatie en vooral of er sprake is van een proces van vernieuwing en verandering. Als dit aan de orde is, is er meer formatie nodig, waarbij overigens leiderschapstaken vaak samengaan met managementtaken. Kotter heeft zich toch aan een percentage gewaagd: $1-50 \%$ van de totale formatie. (2) Maar voor succesvol leiderschap hangt veel af van het moment en de situatie. Met welk type leider is een organisatie op een bepaald moment en in een bepaalde situatie het meest gediend? 


\section{Kwaliteiten in ẻén persoon?}

Een ander interessant punt is in hoeverre de voor goed leiderschap en management vereiste kwaliteiten in eén persoon verenigd moeten of kunnen zijn. De praktijk laat zien dat dat zelden het geval is, ofschoon van een zwart-wit typologie niet echt sprake is.

Belangrijk is dat iemand van zichzelf weet waar zijn of haar kracht ligt en dus ook zijn/haar beperking. Als in een organisatie liemand aan het hoofd staat die primair leiderschapskwaliteiten heeft, hoort het bij die kwaliteit dat hij zorg draagt en ruimte biedt voor goed management. Als de leider intrinsiek meer een managementtype is, dient hij de groep of de organisatie ruimte te geven voor ontwikkelingen die kenmerkend zijn voor hetgeen hoort bij het leiderschapstype. Leider en manager vullen in hun leiderschapsfuncties elkaar aan.

Kan een manager leiderschapskwaliteiten leren? En omgekeerd, een leider managementkwaliteiten? Tot op zekere hoogte well, maar belangrijker is de vraag of dat wel moet en of het de organisatie ten goede komt. Bewust zijn van de eigen kwaliteiten en zorg dragen voor de nodige aanvulling en voor de juiste man op de juiste plaats, lijken de belangrijkste voorwaarden voor het goed functioneren van een leilder en manager en het goed functioneren van een organisatie of groep, tenzi] het om een wel heel kleine groep gaat. Anders gezegd: iemand die de potentie in zich heeft om een goede manager te zijn en dat ook is, moet niet de pretentie hebben dat hij een goed ondernemer of leider is. En iemand met primair leiderschapskwaliteiten, hoeft lang niet altijd zelf managementtaken op zich te nemen, maar hij moet wel zorgen dat er iemand naast hem stal die de beoogde doelen deelt en die zorg draagt dat de uitgezette lijnen worden ontwikkelt en waargemaakt. Met andere woorden de verantwoordelijkheid voor het bepalen van een visie, vervolgens de strategieontwikkeling en tenslotte de uitvoering liggen wel bij hem of haar. 


\section{Een hiërarchie met vijf niveaus}

Op grond van zijn onderzoek stelde Collins een hiërarchie op van topmanagementkwaliteiten. In de terminologie van Kotter, loopt deze lijn van leider naar manager. Collins tekent aan dat ook medewerkers op het laagste niveau, niveau 1, heel succesvol kunnen zijn. Maar, will de organisatie blijvend succeswol zijn, dan is daarvoor niveau 5 nodig. (5) Zie figuur 2.

\section{Figuur 2. De hiërarchie met vijf niveaus volgens Collins}

De leider op Niveau 5 staat bovenaan een hiërarchie van capaciteiten. Volgens ons onderzoek is zijn aanwezigheid een absolute voorwaarde om van een degelijke organisatie een superieure organisatie te maken. Wat ligt er echter onder dit niveau?

Vier lagen, die elk voor zich ook hun nut. hebben, maar die geen van alle de kracht bieden van Niveau 5 . Het is niet nodig dat iemand alle niveaus. doorloopt om de top te bereiken. Een complete leider op Niveau 5 moet echter wel de capaciteiten van alle lagere niveaus bezitten, en daaremboven de bijzondere kenmerken van Niveau 5 zelf.

\section{Niveau 5. Leider op Niveau 5}

Bouwt blivende superioriteit op met behulp van een paradoxale combinatie wan persoonlijke bescheidenheid en beroepsmatige vastberadenheid.

\section{Niveau 4. Doeltreffende leider}

Schept de benodigde betrokkenheid en inspanning voor een duidelijke overtuigende visie; stimuleert de groep om hoge prestatienormen te behalen.

\section{Nivieau 3. Competent manager}

Organiseert mensen en middelen om doeltreffend en doelmatig toe te werken naar vooraf gestelde doelen.

\section{Niveau 2. Doeltreffend teamlid}

Draagt bij aan de prestaties van de groep; werkt doeltreffend samen met anderen in groepsverband.

Niveau 1. Capabele werknemer

Levert doeltreffende bijdragen op grond van talent, kennis, vaardigheden en goede gewoonten in het werk. 
Anders dan Kotter, maakt Collins niet direct een onderscheid tussen de leider en de manager. Bij hem is het meer het in elkaar overgaan van de ene kwaliteit naar de andere. Wissema stelt dat een ondernemer op een gegeven moment zichzelf moet transformeren tot manager. (4) Geplaatst in het schema van Collins is leiderschap te vinden in de niveaus 5 en 4 en management in de niveaus 4 en 3 . Een capabele werknemer is in zijn situatie ook een goed manager, met name omdat hij of zij effectief weet te werken. "In elk van onze kennisorganisaties zijn er mensen die aan niemand leiding geven en toch manager zijn". (6)

\section{Tot slot}

Met de door Kotter genoemde karakterisering zijn leiderschap en management in een verhouding geplaatst die ook van bellang is voor capaciteitsgroepen. Het aardige van Kotter is dat hij op basis van onderzoek een duidelijk onderscheid weet aan te geven tussen leiderschap en management. $\mathrm{Hij}$ toont tevens aan dat leiderschap een noodzaak is om een organisatie tot bloei te brengen. Maar nogmaals, dat lukt niet als er niet tevens sprake is van adequaat management. Een organisatie heeft beide typen leiderschap nodig. Collins benoemt de voorwaarden voor leiderschap die een organisatie tot bloeil kan brengen en die haar stabiliteit en continuiteit geeft.

Met het gemaakte onderscheid zijn leiderschap en management in een verhouding geplaatst die ook belangrijk is voor het onderzoek, het onderwijs en de huisartsenzorg, waar een capaciteitsgroep huisartsgeneeskunde verantwoordelijk voor is. Een vakgroep heeft zowel een ondernemende, inhoudelijk deskundige, leider nodig als een goed management.

Harry Crebolder heeft 16 jaar bij de capaciteitsgroep Huisartsgeneeskunde gewerkt, waarvan vele jaren als voorzitter. $\mathrm{Hij}$ is in die functie gegroeid en in de loop der jaren is hij een echte ondernemer op het gebied van de huisartsgeneeskunde geworden. Het was een genoegen om dat mee te maken en te zien dat hij in de loop der jaren die kwaliteit versterkt heeft. Maar hij wist ook dat het andere stuk leiderschap, het managementdeel, noodzakelijk was. 
Daarover maakte hij afspraken en dat bleef hij ook bewaken en hoe: betrokken, bevlogen zelfs en vooral ook vastberaden. Ik laat het graag aan $u$ als lezer over om, met behulp van de figuren $r$ en 2, Harry in te delen in een van de hiervoor in figuur 2 genoemde niveaus. Als het maar hoog is.

Harry, dank voor de jarenlange goede samenwerking en voor je vriendschap. Het ga je, en ook jou Emma, goed.

\section{Literatuur}

1. Bryman, Alan. Leadership in Organisations. In: Clegg Steward R., Cynthia Hardy and Walter R. Nord. Handbook of Organisation Studies. London-Thousand Oaks-New Delhi: Sage Publications, 1996: 276-92

2. Kotter, John P. A Force for Change. How Leadership differs from Management. New York: The Free Press, 1990

3. Zaleznik. A. Managers and leaders: are they different? Harvard Business Review 1977: 55:67-78

4. Wissema, J.G. De kunst van strategisch ondernemerschap. Een nieuwe kijk op strategie. Groningen/Houten:

Stenfert Kroese, 2001

5. Collins, Jim. Leidinggeven op Niveau 5 - de triomf van bescheidenheid en vastberadenheid. Holland Management

Review 2001; 77: 42-53

6. Drucker, Peter F., De effectieve manager. Amsterdam:

Uitgevereij Nieuwezijds, 2001.

Dr. J.M.H. op 't Root is Universitair Hoofddocent en hoofd van de sector basiscurriculum bij de Capaciteitsgroep Huisartsgeneeskunde van de UM. 


\section{Harry Crebolder, een man met vele gezichten!}

René Kocken.

Je ontmoet in je leven vele mensen. Sommigen zijn in jouw ogen onbetekenend en worden snel vergeten. Anderen maken op de één of andere maniler een onuitwisbare indruk op je en blijven dan ook een leven lang in het geheugen geactiveerd. Het zal u niet verbazen dat Harry Crebolder tot de laatste categorie behoort.

De eerste ontmoeting kan ik me absoluut niet meer herinneren, maar aangenomen mag worden dat het Gezondheidscentrum Withuis de locatie was, allwaar die ontmoeting invulling kreeg. Harry Crebolder als huisarts en ikzelf als vertegenwoordiger van de Universiteit Maastricht in een ingewikkeld academiseringsproces. En Harry was niet zo maar een huisarts in dat gezondheidscentrum; nee, hij was de "primus interparis". Hij vervulde nadrukkelijk de leidinggevende rol en in de besprekingen tussen hem en mij begon het al meteen te gloeien.

Het kon dan ook geen toeval zijn dat Harry benoemd werd tot hoogleraar aan de UM. Hij ging zich bezig houden met de interessante, maar op het eerste gezicht weinig zeggende leeropdracht met de naam "Eerste Lijn Onderwijscoördinator". Het leek een belangrijke functie want er was een zogenaamd "spiderman-rapport" over geschreven. Ik vroeg me als jong broekie toen al af wat die man nu precies ging doen. "Spiderman" klonk zo "James Bond-achtig".

Maar je zag er wel degelijk uit als een spiderman. Angstaanjagend, uitbundig, emotioneel en in ieder geval doelgericht.

Al snel bleek dat jouw eigenlijke ambitie de normale leeropdracht "Huisartsgeneeskunde"was. Je was en bleef per slot van rekening "die eenvoudige dokter uit Venlo", en dat zou je ons nog vaak vertellen. Jouw hart was bij de Huisartsgeneeskunde en dan in het bijzonder bij de academisering, het betrekken van perifere huisartsen bij de academie.

En ik moet zeggen, daarin ben je wel degelijk geslaagd, al vind ik 
natuurlijk dat (je kent me per slot van rekening als arrogant en zelfbewust) dat ik daarin een uitermate grote rol heb vervuld. Maar dit ter zijde.

Onze relatie heeft zicht gevormd in twee belangrijke fases. De eerste fase betrof onze samenwerking in de capaciteitsgroep

Huisartsgeneeskunde, jij als voorzitter en ik als beheerder. Prachtige discussies waren dat in onze periodiek overleggen. We vonden steeds weer dat we beide gelijk hadden en reageerden daar ook naar. Allebel nogal driftig soms, allebei met veel emotie en vooral allebei met een grote betrokkenheid voor de Huisartsgeneeskunde. De discussies waren geestdriftig en eindigden zeker niet altijd in een compromis. Dat kon ook niet want jij bent een aamhanger van het compromismodel, terwijl mijn voorkeur (nog steeds) bestaat uit de hantering van "conflictmodellen", In dat opzicht was jij wel een verdomd aardige sparringpartner, want conflicten kan je met jou wel uitvechten.

De tweede fase in onze relatieopbouw betrof de afronding van mijn eigen proefschrift. Jij als medepromotor en ik als hard werkende promovendus. Ook hier waren we het dikwijls oneens, maar gelukkig verkeerde ik hier in een andere positie. Met slechts enkele kleine tekstuele wijzigingen slaagde ik er toch in mijn "zin" door te drijven.

Weet je trouwens dat jij nog een onuitwisbare indruk hebt achtergelaten bij Anita, mijn echtgenote. Tijdens een bespreking van het manuscript bij mij thuis in het Sittardse, schoof $\mathrm{jij}$ zo hard met jouw koffiemok en het daarbij behorende vlabord over de tafel, dat wij nog dagelijks tegen (wat wij noemen) een promotie-kras aankijken. We noemen dit liefdevol en met gevoel voor understatement "de kras van Harry".

In mijn dankwoord schreef ik o.a. over jou : "Als er ergens een haatliefde verhouding bestaat, dan is het tussen Harry en mij. Overeenstemming is er meestal over de einddoelen die nagestreefd worden; verschil van mening over de wegen waarlangs die doelen bereikt moeten worden". 
Dat was toen waar en volgens mij nu nog steeds. Het was toen overigens ook nog diplomatiek opgeschreven, want ik wist dat ik waarschijnlijk nog enkele jaren met jou zou moeten (mogen) samenwerken. Echter al vrij snel scheidden onze wegen. Jij bleef die huisarts, ik ging het centraler zoeken, eerst als controller, later als adjunct-directeur FdG en nog later als directeur ICTS. Onze wegen bleven zich echter kruisen, eerst in de faculteitsraad en later incidenteel, op de gang of ergens anders.

Nu bij jouw afscheid kan ik de diplomatie achter me laten en eens eerlijk mijn mening geven. Want wat heb ik vaak gezegd, als je weer eens moeilijk deed:

"Harry, dat is een aardige kerel, hij moest alleen niet hier werken" of "Een manager zal hij nooit worden, al heeft hij de beste bedoelingen".

Harry, van iedereen waar je mee werkt en leeft neem je dingen mee en ik vind het op dit moment gepast aan te geven wat ik van jou heb meegenomen.

Dat is allereerst jouw gedrevenheid, want die heeft nooit buiten kijf gestaan. Je kwam met doelen, je zag de doelen en je overwon met de doelen.

Een tweede opmerkelijke kwaliteit is jouw gevoel voor "netwerken". Je verkeert graag en veelvuldig in de "hogere kringen" en wilt daar altijd zaken doen.

Over jouw humeur kan in zijn algemeen gezegd worden, dat daar niets mis mee is. Meestal goede zin, soms stond het gezicht op onweer.

En als ik de verhalen moet geloven was en ben jij een slecht, roekeloos rijder. Dat is de reden waarom ik steeds weer smoesjes verzon, om maar niet als co-driver van jou te hoeven fungeren.

Harry, je kunt terugkijken op een moeilijke, maar vruchtbare loopbaan. Het neerzetten van een gezondheidscentrum en het uitbouwen van een brede, academische, capaciteitsgroep Huisartsgeneeskunde is geen sinecure. Jij hebt daar een meer dan gemiddeld steentje aan bij gedragen en daarvoor heb ik uitermate veel bewondering. 
Ik wens jou, mede namens Anita, Tim en Dennis, een fijn afscheid en ben er van overtuigd dat de komende jaren met Emma, de kinderen en kleinkinderen minstens even plezierig en vruchtbaar mogen zijn.

Dr. R.J.J. Kocken was beheerder bij de Capaciteitsgroep Huisartsgeneeskunde van de UM en coördinator van het Coördinatiebureau Eerste Lijn. Momenteel is hij hoofd van het Informatie Communicatie Technologie Servicecentrum van de UM. 


\section{B eheer: van punaise tot pre-advies}

Ellen Breevoort.

Beste Harry,

Ter gelegenheid van jouw afscheid sta ik stil bij 11 jaar van mijn carrière. In die periode heb ik de stap gemaakt van assistentbeheerder Huisartsgeneeskunde naar beheerder Huisartsgeneeskunde en tenslotte naar hoofd Gemeenschappelijk Beheersbureau (GBB).

Deze ontwikkeling heb ik mede aan jou te danken. Jij hebt mij altijd onvoorwaardelijke steun en mogelijkheden geboden. $k$ wist me altijd verzekerd van een baas, die achter me stond.

Jij vertrouwde helemaal op me. Dit vertrouwen was in het algemeen uiteraard prettig; soms echter was het ook een extra zware druk. Wetende dat jij mij nauwlettend volgde was ik soms bang om fouten te maken. Uiteindelijk heeft het echter erin geresulteerd dat ik zelfbewuster en zekerder ben geworden. Jij wist dus blijkbaar tóch heel goed hoe met mij om te gaan.

In die elf jaar is heel wat gebeurd. De academisering en het totale netwerk heeft zich ontwikkeld tot een niet meer weg te denken proces van samenwerking met het huisartsensveld. De relatie met het azM is mede door jouw nooit aflatende doorzettingsvermogen beter dan ooit. De capaciteitsgroep heeft zich ontwikkeld tot niet alleen de grootste maar ook de meest complexe en interessante van de Faculteit der Geneeskunde. Van capaciteitsgroep naar vakgroep en van valkgroep terug naar capaciteitsgroep.

Meerdere conflicten hebben we samen uitgevochten met het faculteitsbestuur of het college van bestuur. De toelagen voor de HAB's, de huisvestingskosten van de huisartsopleiding zijn slechts enkele voorbeelden. Ik stond iedere keer opnieuw verstell van jouw vastberadenheid.

Ook samen hadden we wel eens meningsverschil. Dat ging dan meestal om de alom bekende strijd tussen beleid en beheer. Jij stond altijd voor de inhoud; ik woor de financiële haalbaarheid van een plan. 
In deze meningsverschillen heb ik altijd het respect voor elkaar gewaardeerd. Ik wist in ieder geval dat jij nooit een verborgen agenda had; iets wat in de universitaire wereld naar mijn mening veel te veel voor komt. Ik heb hiermee moeten leren leven. Een universiteit is nu eenmaal een gemeenschap met professionals, heb ik van jou geleerd. Ik heb daarbij altijd geprobeerd om aan te tonen dat beheerders ook professionals zijn en als zodanig behandeld zouden moeten worden. Te vaak echter moest het beheer inschikken bij de prioriteit voor het beleid. Dat is jammer, omdat ik nog steeds geloof dat beleid en beheer gelijkwaardig zijn en er alleen een gezond bedrijf kan ontstaan indien uitsluitend inhoudelijk verantwoorde, maar ook beheersmatig getoetste projecten uitgevoerd worden. lk heb de indruk dat ik deze gedachte in al die jaren van samenwerking bij jou heb kunnen overbrengen. Jij bent in ieder geval veel meer bedrijfsmatig gaan denken. lets wat ik zeer waardeer.

De instituutsvorming en de komst van de integrale budgettering heeft de laatste jaren veel van onze aandacht en inzet opgeëist. Deze ontwikkeling was voor ons allen, maar zeker voor jou, niet gemakkelijk. Als een leeuw vocht je voor het voortbestaan van jouw vakgroep, maar vooral voor de essentie van het vakgebied. Van een volkomen scepticus heb je je geleidelijk veranderd in iemand die gelooft in de scheiding van verantwoordelijkheden van proceseigenaren van onderwijs, onderzoek en het eigen vakgebied. Echter wél altijd onder de voorwaarde van wederzijds respect. Deze ontwikkeling bracht voor mij het bekende pettenprobleem. Mijn loyaliteit voor HAG moest ik voortaan delen met ExTra en CaRe. Soms heel moeilijk, maar ik heb geleerd om iedere situatie te beoordelen naar rechtvaardigheid zonder stil te staan bij de vraag wie of wat ik moest dienen. $\mathrm{k}$ heb me daarbij voortdurend gerealiseerd dat ik in de eerste plaats beheerder was en verantwoordelijk voor de financiën en het personeel, ongeacht ten behoeve van welk beheersgebied.

Samenvattend kan ik zeggen dat ik er uitermate trots op ben dat ik al die jaren aan jouw zijde heb mogen werken. Je was voor mij een fantastische baas en een geweldig mens om mee om te gaan. Jouw 
deur stond altijd open. Daarvoor ben ik je zeer dankbaar. ik weet zeker dat we je enorm gaan missen. Echter jouw werk zit er meer dan op. Ik hoop daarom dat je de komende tijd met plezier kan terugkijken op een glanzende carrière als arts én hoogleraar, terwijl je hopelijk heel veel gaat genieten van mooie reizen, je vrouw, kinderen en kleinkinderen.

Harry, het ga je goed!!!!

Mevr. E.L.M.G. Breevoort is hoofd van het Gemeenschappelijk BeheersBureau van de Capaciteitsgroep Huisartsgeneeskunde en het Onderzoeksinstituut ExTra van de UM. 


\section{E en goede toekomst ligt in een rijk verleden}

Yvonne van Leeuwen.

"Zomaar, op een mooie junidag, doet hij de deur voor de laatste maal dicht en zwaait zijn nog altijd volle lichtbruin leren schoudertas over zijn rechthoekige rechter schouder".

Harry gaat weg. Als je hem vraagt hoe dat voelt, lacht hij veriegen. .... maar ook ik kom niet goed uit mijn woorden.

Het is soms niet eenvoudig uit te leggen hoe je iemand zult missen.

Harry was mijn 'werkbaas'. Niet altijd inspireren die. Harry wel. Zelden met spektakel en wapengekletter. Wel met frapper toujours. Waarop? Hoe?

Allereerst met lezen. I zal niet de enige zijn die geregeld - meestal na een weekend - een paar artikeltjes onder de neus geschoven kreeg: 'interessant voor jou', 'je zei toch laatst dat je hierin geïnteresseerd was'. 'Ken je literatuur', was ook de boodschap.

Manager zijn, coachen en dan de tijd nemen voor echt aandachtig lezen! Dat deed hij gewoon.

Harry 'stond op het verleden': Bekijk de huisartsgeneeskunde in de tijd. Volg de lijn van ontwikkelingen, ook de lijn terug. Weet wie hebben bijgedragen: Frans Huygen, vele anderen. Ook Jo Baggen kwam in het rijtje voor. Harry schonk hem een symposium: Met het oog op de meester, voor zijn revolutionaire oog-lessen en zijn jaren 70-pleidooi voor differentiatie, nu gemeengoed. Credit aan degenen die hun nek uitsteken. Weten op wiens schouders je staat. Harry zette de lijn voort met de kadertraining $5 \mathrm{GO}$, waar ik het voorrecht had aan deel te mogen nemen.

Harry preekte de eenheid, tussen de secties en de scholen, tussen basis - en beroeps, academie en veld. We moesten soms om beurten in de biechtstoel, als we de sector-besognes voorrang gaven boven het 'nut van het algemeen'. Hét bindmiddel was en is het vak, de huisartsgeneeskunde en haar uitgangspunten. Het debat moe(s)t gaande blijven. Hij waakte daarover als een goede vader. De echo van zijn stimulerende woorden en vermanende zinnen zal nog lang naklinken. 
Harry bewees dagelijks dat hij het meende: dat multidisciplinair werken van hullpverleners de patiënt zeer ten goede zou komen. $\mathrm{Hij}$ schreef en sprak er over. In zijn leven stelde hij vele elftallen samen; Venlo was zijn beroemdste. Hij was zelf ook een echte teamspeler. Het aangeven van de bal en anderen laten scoren, daar was hij goed in. De laatste jaren bloeide zijn liefde voor de specialist, en smeedde hij nieuwe en lenige banden met het ziekenhuis. Af en toe dacht je: wat doet hij nu, maar hij krijgt een flinke portie gelijk aan zijn kant: als eerste en tweede lijn elkaar de bal blijven toespelen, haakt de patiënt (!) af (en vertrekt naar Belgiël?!).

Complementair aan zijn pleidooi voor teamwork was zijn pleidooi voor het medische profiel van de huisarts. Juist als anderen mede hulpverlener zijn kan de dokter dokteren. "Daar is hij goed in en daar is hij voor opgeleid". Meer dan eens vroeg hij mij om me in te zetten voor de medische signatuur van de huisartsopleiding. En als ik dan toch bezig was: meer wetenschap in die opleiding, meer kennis van de besliskunde en als ik dan nog steeds bezig was: dat epidemiologisch paradigma, wat dacht ik daarvan? Zou er niet een verdere vertaling te maken zijn van populatiegeneeskunde naar medische zorg voor de individuele patiënt?

Hij zwaaide Jo en mij lof toe voor onze publicaties hierover.

En dan is er nog dat vermoeide gevecht met de bureaucratie over zaken waar je je eigenlijk niet mee bezig zou willen houden. Als je op een Kafka-muur van regels en bijbehorende bewakers stuitte, was Harry soms James Bond die op motorfietsen over daken reed. Stuntwerk! Hij was mij toegedaan, als hoofd van de huisartsopleiding die hem na aan het hart lag. Hij was mij ook toegedaan als persoon. Vaker klaagde ik mijn nood over het krankzinnige werktempo en de eeuwige nooit slinkende stapel 'Unvollendetes'. Als ik vroeg of hij er zelf geen last van had en misschien ook wel eens wakker lag, lachte hij verlegen.

Een ding kon hij absoluut niet hebben: doemdenken. "Het is afgelopen met de huisartsgeneeskunde', zeg het niet in zijn bijzijn. Wat niet wegneemt dat hij weet dat het oppassen geblazen is, met de 
huisartsgeneeskunde, zo hier op de drempel van de ziste eeuw. Toon Telligen weet dat ook:

Lange tijd gaat het goed,

Stromen de rivieren vriendelijk naar zee,

Bloeien de bloemen,

Dartelen de vlinders,

Slapen de filosofen in de brede schaduw van het dualisme,

Geven mensen elkaar gelijk,

Is het leven zacht en grootmoedig,

Fluisteren meisjes in een oor:

Laten we.... enzovoort,

O, laten we altijd....enzovoort....

Heel lang gaat het goed,

Onwaarschijnlijk lang gaat het onwaarschijnlijk goed,

Het gaat nog altijd goed,

Zelfs nu gaat het nog goed,

En nu.

We houden het vak overeind, Harry. Belofte maakt schuld en ik zal je missen.

En Jo: die weet je te vinden om het een na het andere paradigma filosofisch te schuren, te logen en te beitsen.

Mede namens Jo Baggen, honorair docent capaciteitsgroep huisartsgeneeskunde, Paul Ram en de staf van de Huisartsopleiding. Dr. Y. van Leeuwen, huisarts, Hoofd huisartsopleiding van de UM. 


\section{Goeie moed Harry, ut kump good'}

Ine Siegelaer.

Beste Harry,

$\mathrm{Mij}$ is gevraagd een stukje voor jou te schrijven. Deze mogelijkheid heb uiteraard ik met beide handen alangegrepen. Ik vind het dan ook een hele eer om dit te mogen doen.

Ik heb je zestien jaar geleden leren kennen. Jij kwam op je 'eigen karakteristieke Harry manier' bij ons (de capaciteitsgroep Huisartsgeneeskunde) binnen.

Die manier kende ik niet...... en wat heb ik daar aan moeten wennen! We hebben in onze beginperiade heel wat hobbels moeten nemen, gesprekken moeten voeren om te komen waar we nu zijn. Het gewenningsproces was gelukkig wederzijds.

Zestien jaar, een hele tijd, werk ik nu samen, met en voor Harry. Deze samenwerking is uitgegroeid tot iets moois. Een goed team dat respect heeft voor elkaar, er is voor elkaar. Samen lachen, samen huilen! 'Goede moed, meisje', een uitspraak waar ik nog vaak aan zal denken. Een schouderklopje, nog eens informeren. Altijd betrokken, meelevend, belangstellend, eerlijk. Kortom een heel fijn persoon om te kennen, om als baas te hebben!

Het moge duidelijk zijn dat ik je zal missen. Je bent niet alleen mijn baas, maar toch zeker ook mijn danspartner. Is er feest, Harry is van de partij. Je swingt, danst en feest gezellig met ons mee. le bent ook dan 'onze' Harry, op allerlei gebied.

En nu is het dan zover. Je gaat het rustiger aan doen. Want helemaal weg zijn, daar geloof ik nog niet zo in. Je zult zeker nog door de gang dwalen, bij allerlei zaken betrokken blijven.

Maar toch Harry, het zal voor mij erg wennen zijn. Ik zal je heel erg missen. Harry bedankt voor alles, ik ben er trots op jouw secretaresse te zijn geweest.

Ik wens je, mede namens Peter, Suzanne en Xavier, nog heel veel gezonde en gelukkige jaren.

Mevr. I. Siegelaer-Gerardu is capaciteitsgroepsecretaresse van de capaciteitsgroep Huisartsgeneeskunde van de UM. 